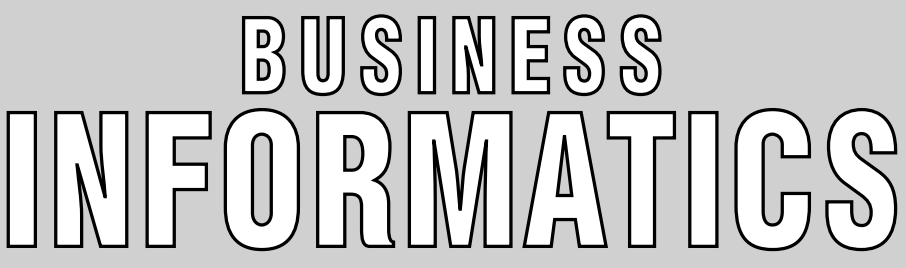

HSE SCIENTIFIC JOURNAL

\section{CONTENTS}

\section{Modeling of social and economic systems}

L. Fici, P.V. Malyzhenkov, M. Piccarozzi,

\section{E.S. Meleshina}

Spin-off design as an organizational practice:

A methodological approach

E.A. Babkin, O.V. Radzinskaya

Application of the Eclipse EMF technology

for multifaceted organization modelling.

\section{D.S. Bidzhoyan, T.K. Bogdanova}

Modelling the financial stability of an enterprise taking into account macroeconomic indicators

\section{Information systems and technologies in business}

S.M. Avdoshin, E.Yu. Pesotskaya

Mobile healthcare: Perspectives in Russia 38

\section{E.V. Kuznetsova}

Budgeting automation in construction companies

\section{D.S. Pashchenko}

Identification of the main problems of change management in software development companies:

Research in the CEE region 54

\section{Business processes modeling and analysis}

\section{I.G. Fiodorov}

Overcoming expressiveness deficit of business process modeling languages

A.I. Gromov, Yu.A. Bilinkis, N.S. Kazantsev, A.G. Zueva Applying Extended DMAIC methodology to optimize weakly structured business processes 72

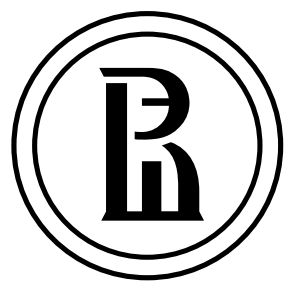

Publisher:

National Research University Higher School of Economics

Subscription index in the «Rospechat» catalogue 72315

The journal is published quarterly

The journal is included into the list of peer reviewed scientific editions established by the Supreme Certification Commission of the Ministry of Education and Science of the Russian Federation

Editor-in-Chief:

A. Golosov

Deputy Editor-in-Chief

Y. Koucheryavy

Computer Making-up: O. Bogdanovich

Website Administration:

I. Khrustaleva

Address:

33, Kirpichnaya Street, Moscow, 105187, Russian Federation

Tel./fax: +7 (495) 771-32-38 http://bijournal.hse.ru

E-mail: bijournal@hse.ru

Circulation - 500 copies

Printed in HSE Printing House

3, Kochnovsky Proezd, Moscow, Russian Federation

(C) National Research University Higher School of Economics 
$\mathrm{B}$

usiness Informatics is a peer reviewed interdisciplinary academic journal published since 2007 by National Research University Higher School of Economics (HSE), Moscow, Russian Federation. The journal is administered by School of Business Informatics. The journal is published quarterly.

The mission of the journal is to develop business informatics as a new field within both information technologies and management. It provides dissemination of latest technical and methodological developments, promotes new competences and provides a framework for discussion in the field of application of modern IT solutions in business, management and economics.

The journal publishes papers in the areas of, but not limited to:

$\downarrow$ data analysis and intelligence systems

$\checkmark$ information systems and technologies in business

$\uparrow$ mathematical methods and algorithms of business informatics

$\downarrow$ software engineering

$\downarrow$ Internet technologies

$\uparrow$ business processes modeling and analysis

$\uparrow$ standardization, certification, quality, innovations

$\uparrow$ legal aspects of business informatics

$\downarrow$ decision making and business intelligence

$\uparrow$ modeling of social and economic systems

$\uparrow$ information security.

The journal is included into the list of peer reviewed scientific editions established by the Supreme Certification Commission of the Ministry of Education and Science of the Russian Federation.

The journal is included into Russian Science Citation Index (RSCI) database on the Web of Science platform.

International Standard Serial Number (ISSN) 1998-0663.

Editor-in-Chief: Dr. Alexey Golosov - President of FORS Development Center, Moscow, Russian Federation. 


\section{EDITORIAL BOARD}

\section{EDITOR-IN-CHIEF}

Dr. Alexey GOLOSOV -

President of FORS Development Center, Russian Federation

\section{DEPUTY EDITOR-IN-CHIEF}

\section{Dr. Yevgeni KOUCHERYAVY -}

Professor, Department of Electronics and Communication Engineering, Tampere University of Technology, Finland

\section{EDITORIAL BOARD}

\section{Dr. Habib ABDULRAB -}

Professor, Mathematical and Software Engineering Department, National Institute of Applied Sciences - Institut national des sciences appliquées de Rouen (INSA de Rouen), Rouen, France

\section{Dr. Sergey AVDOSHIN -}

Professor, Head of School of Software Engineering,

National Research University Higher School of Economics, Russian Federation

\section{Dr. Andranik AKOPOV -}

Professor, Department of Business Analytics, National Research University Higher School of Economics, Russian Federation

\section{Dr. Fuad ALESKEROV -}

Professor, Head of Department of Mathematics, National Research University Higher School of Economics, Russian Federation

\section{Dr. Anton AFANASYEV -}

Leading Researcher, Laboratory of Social Modeling, Central Economics and Mathematics Institute, Russian Academy of Science, Russian Federation

\section{Dr. Eduard BABKIN -}

Professor, Department of Information Systems and Technologies, National Research University Higher School of Economics, Russian Federation

\section{Dr. Alex BAYER -}

Head of KAFAN FX Information Services, New York, USA

\section{Dr. Alexander BARANOV}

Deputy Head of Central Scientific and Research Computing Center, Federal Tax Service of Russia, Russian Federation

\section{Dr. Jorg BECKER -}

Vice-Rector, Professor, Director of European Research Center for Information Systems (ERCIS), University of Munster, Germany

\section{Dr. Vladimir BELOV}

Professor, Department of Computational and Applied Mathematics, Ryazan State Radio Engineering University, Russian Federation

\section{Dr. Andrey GRIBOV -}

Director General, CyberPlat Company, Russian Federation

\section{Dr. Alexander GROMOV-}

Professor, Head of Department of Modeling and Business Process Optimization, National Research University Higher School of Economics, Russian Federation

\section{Dr. Vladimir GURVICH -}

Invited Professor and Researcher, Rutgers Center for Operations Research, Rutgers, The State University of New Jersey, USA

\section{Dr. Laurence JACOBS -}

Professor, Medical School, University of Zurich, Switzerland

\section{Dr. Iosif DISKIN -}

Academic Supervisor, Chairmen of Scientific and Expert Council, Russian Public Opinion Research Center (VCIOM); Member of the Council, The Russian Public Chamber; Russian Federation

\section{Dr. Kurt SANDKUHL -}

Professor, Head of Department of Business Information Systems, University of Rostock, Germany

\section{Dr. Nikolay ILYIN -}

Deputy Head, Administration of Special Communication, Federal Security Guard, Russian Federation

\section{Dr. Dmitry ISAEV -}

Associate Professor, Department of Business Analytics, National Research University Higher School of Economics, Russian Federation

Dr.Valery KALYAGIN -

Professor, Head of Department of Applied Mathematics and Informatics, National Research University Higher School of Economics, Russian Federation

Dr. Maria KAMENNOVA -

Director General, BPM Logic, Russian Federation

Dr. Tatiana KRAVCHENKO -

Professor, Head of Department of Business Analytics, National Research University Higher School of Economics, Russian Federation

\section{Dr. Sergey KUZNETSOV -}

Professor, Head of School of Data Analysis and Artificial Intelligence, National Research University Higher School of Economics, Russian Federation

\section{Dr. Mikhail LUGACHEV -}

Professor, Head of Department of Economic Informatics, Lomonosov Moscow State University, Russian Federation

\section{Dr. Svetlana MALTSEVA -}

Professor, Head of Department of Innovation and Business in Information Technologies, National Research University Higher School of Economics, Russian Federation

\section{Dr. Peter MAJOR -}

Vice-chairman, Radiocommunication Advisory Group of International Telecommunication Union (ITU),

vicece-chairman of the UN Commission on Science and Technology for Development (CSTD), Geneva, Switzerland

\section{Dr. Boris MIRKIN -}

Professor, School of Data Analysis and Artificial Intelligence, National Research University Higher School of Economics, Russian Federation

Dr. Vadim MOTTL -

Professor, Department of Information Security Management, Tula State University, Russian Federation

\section{Dr. Dmitry PALCHUNOV -}

Head of Department of General Informatics, Novosibirsk State University, Russian Federation

\section{Dr. Panagote (Panos) PARDALOS -}

Distinguished Professor and University of Florida Research

Foundation Professor, Director of Center for Applied Optimization, Department of Industrial and Systems Engineering, University of Florida, USA

Dr. Albert SILANTYEV -

Professor, Department of Information Business Systems, National University of Science and Technology «MISIS», Russian Federation

\section{Dr. Victor TARATOUKHIN -}

Managing Director, European Research Center for Information Systems (ERCIS), University of Munster, Germany

Dr. Mikhail ULYANOV -

Professor, School of Software Engineering,

National Research University Higher School of Economics,

Russian Federation 


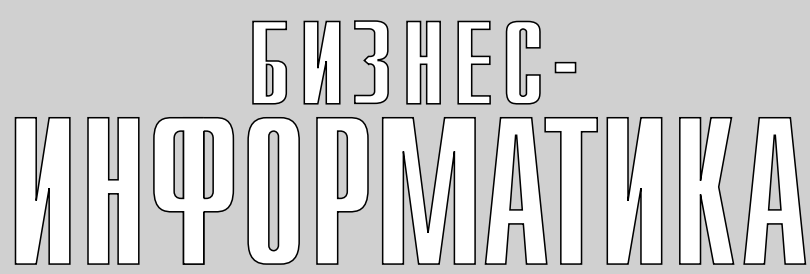

НАУЧНЫЙ ЖУРНАЛ НИУ ВШЭ

\section{С ОДЕРЖАН И Е}

\section{Моделирование социальных и экономических систем}

Л. Фичи, П.В. Малыженков, М. Пиккароцци, Е.С. Мелешина

Проектирование спин-оффов как организационная практика: Методологический подход

\section{Э.А. Бабкин, О.В. Радзинская}

Применение технологии Eclipse EMF

для многоаспектного моделирования организации

\section{Д.С. Биджоян, Т.К. Богданова}

Моделирование финансовой устойчивости предприятия

с учетом макроэкономических показателей 30

\section{Информационные системы и технологии в бизнесе}

С.М. Авдошин, Е.Ю. Песоцкая

Мобильное здравоохранение:

Перспективы в России.

E.В. Кузнецова

Автоматизация бюджетирования

в строительных компаниях

\section{Д.С. Пашенко}

Основные проблемы управления изменениями

в компаниях, разрабатывающих программное

обеспечение: Исследование в Центральной

и Восточной Европе

\section{Моделирование и анализ бизнес-процессов}

\section{И.Г. Фёдоров}

Преодоление дефицита выразительной способности языков моделирования бизнес-процессов

А.И. Громов, Ю.А. Билинкис, Н.С. Казанцев,

А.Г. Зуева

Применение расширенной методологии DMAIC

для оптимизации слабоструктурированных

процессов

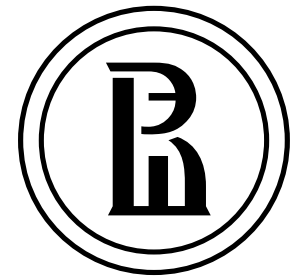

Издатель:

Национальный исследовательский университет «Высшая школа экономики»

Подписной индекс

в каталоге агентства

«Роспечать» -72315

Выпускается ежеквартально

Журнал включен в Перечень российских рецензируемых научных жмурналов,

в которых должны быть

опубликованы основные научные

результаты диссертаций на соискание ученых степеней доктора и кандидата наук

Главный редактор А.О. Голосов

Заместитель главного редактора Е.А. Кучерявый

Компьютерная верстка О.А. Богданович

Администратор веб-сайта И.И. Хрусталёва

Адрес редакции: 105187, г. Москва, ул. Кирпичная, д. 33

Тел./факс: +7 (495) 771-32-38 http://bijournal.hse.ru

E-mail: bijournal@hse.ru

За точность приведенных сведений и содержание данных,

не подлежащих открытой публикации, несут ответственность авторы

При перепечатке ссылка на журнал «Бизнес-информатика» обязательна

Тираж 500 экз.

Отпечатано в типографии НИУ ВШЭ г. Москва, Кочновский проезд, 3

(c) Национальный исследовательский университет «Высшая школа экономики» 


\section{O XКРНA^E}

$\ll \mathrm{B}$

изнес-информатика» - рецензируемый междисциплинарный научный журнал, выпускаемый с 2007 года Национальным исследовательским университетом «Высшая школа экономики» (НИУ ВШЭ). Администрирование журнала осуществляется школой бизнес-информатики НИУ ВШЭ. Журнал выпускается ежеквартально.

Миссия журнала - развитие бизнес-информатики как новой области информационных технологий и менеджмента. Журнал осуществляет распространение последних разработок технологического и методологического характера, способствует развитию соответствующих компетенций, а также обеспечивает возможности для дискуссий в области применения современных информационно-технологических решений в бизнесе, менеджменте и экономике.

Журнал публикует статьи по следующей тематике:

\ анализ данных и интеллектуальные системы

४ информационные системы и технологии в бизнесе

\ математические методы и алгоритмы бизнес-информатики

программная инженерия

$\uparrow$ Интернет-технологии

моделирование и анализ бизнес-процессов

$\checkmark$ стандартизация, сертификация, качество, инновации

$\checkmark$ правовые вопросы бизнес-информатики

↔ринятие решений и бизнес-интеллект

моделирование социальных и экономических систем

$\checkmark$ информационная безопасность.

В соответствии с решением президиума Высшей аттестационной комиссии Российской Федерации журнал включен в Перечень российских рецензируемых научных журналов, в которых должны быть опубликованы основные научные результаты диссертаций на соискание ученых степеней доктора и кандидата наук, по следующим группам научных специальностей: 05.13 .00 - информатика, вычислительная техника и управление; 05.25 .00 - документальная информация; 08.00.00 - экономические науки.

Журнал входит в базу Russian Science Citation Index (RSCI) на платформе Web of Science.

Журнал зарегистрирован Федеральной службой по надзору в сфере связи, информационных технологий и массовых коммуникаций (Роскомнадзор), свидетельство ПИ № ФС77-66609 от 08 августа 2016 г.

Международный стандартный серийный номер (ISSN) 1998-0663.

Главный редактор: Голосов Алексей Олегович, кандидат технических наук, Президент компании «ФОРС - Центр разработки». 


\section{ГЛАВНЫЙ РЕДАКТОР}

ГОЛОСОВ Алексей Олегович -

кандидат технических наук, Президент компании «ФОРС Центр разработки»

\section{ЗАМЕСТИТЕЛЬ ГЛАВНОГО РЕДАКТОРА}

КУЧЕРЯВЫЙ Евгений Андреевич -

$\mathrm{PhD}$, профессор департамента электроники и коммуникаций, Технологический университет Тампере, Финляндия

\section{ЧЛЕНЫ РЕДКОЛЛЕГИИ}

АБДУЛЬРАБ Абиб -

$\mathrm{PhD}$, профессор департамента математики и программной инженерии, Национальный институт прикладных наук, Руан, Франция

\section{АВДОШИН Сергей Михайлович -}

кандидат технических наук, профессор, руководитель департамента программной инженерии, Национальный исследовательский университет «Высшая школа экономики»

\section{АКОПОВ Андраник Сумбатович -}

доктор технических наук, профессор кафедры бизнес-аналитики, Национальный исследовательский университет

«Высшая школа экономики»

\section{АЛЕСКЕРОВ Фуад Тагиевич -}

доктор технических наук, профессор, руководитель департамента математики, Национальный исследовательский университет «Высшая школа экономики»

\section{АФАНАСБЕВ Антон Александрович -}

доктор экономических наук, и.о. ведущего научного сотрудника лаборатории социального моделирования, Центральный экономико-математический институт РАН

\section{БАБКИН Эдуард Александрович -}

кандидат технических наук, $\mathrm{PhD}$, профессор кафедры информационных систем и технологий, Национальный исследовательский университет «Высшая школа экономики»

\section{БАЙЕР Алекс -}

$\mathrm{PhD}$, Директор KAFAN FX Information Services, Нью-Йорк, США

\section{БАРАНОВ Александр Павлович -}

доктор физико-математических наук, заместитель директора ФГУП «Главный научно-исследовательский вычислительный центр Федеральной налоговой службы»

\section{БЕККЕР Йорг -}

$\mathrm{PhD}$, проректор, профессор, директор Европейского исследовательского центра в области информационных систем (ERCIS) Мюнстерского университета, Мюнстер, Германия

\section{БЕЛОВ Владимир Викторович -}

доктор технических наук, профессор кафедры вычислительной и прикладной математики, Рязанский государственный радиотехнический университет

\section{ГРИБОВ Андрей Юрьевич -}

кандидат экономических наук, Генеральный директор компании «КиберПлат»

\section{ГРОМОВ Александр Игоревич -}

кандидат химических наук, профессор, заведующий кафедрой моделирования и оптимизации бизнес-процессов, Национальный исследовательский университет «Высшая школа экономики»

\section{ГУРВИЧ Владимир Александрович -}

$\mathrm{PhD}$, приглашенный профессор и исследователь,

Центр исследования операций, Ратгерский университет (Университет Нью-Джерси), США

\section{ДЖЕЙКОБС Лорени -}

$\mathrm{PhD}$, профессор медицинского факультета, Университет Цюриха, Швейцария

\section{ДИСКИН Иосиф Евгеньевич -}

доктор экономических наук, научный руководитель, председатель Научно-экспертного совета, Всероссийский центр изучения общественного мнения (ВЦИОМ); член Совета Общественной палаты Российской Федерации
ЗАНДКУЛЬ Курт -

$\mathrm{PhD}$, заведующий кафедрой информационных систем для бизнеса, Университет Ростока, Германия

\section{ИЛЬИН Николай Иванович -}

доктор технических наук, член-корреспондент Академии криптографии РФ, заместитель начальника Управления специальной связи, Федеральная служба охраны Российской Федерации (ФСО России)

\section{ИСАЕВ Дмитрий Валентинович -}

кандидат экономических наук, доцент кафедры бизнес-аналитики, Национальный исследовательский университет

«Высшая школа экономики»

\section{КАЛЯГИН Валерий Александрович -}

доктор физико-математических наук, профессор, заведующий кафедрой прикладной математики и информатики, Национальный исследовательский университет «Высшая школа экономики»

\section{КАМЕННОВА Мария Сергеевна -}

кандидат технических наук, Генеральный директор компании «Логика ВРМ»

\section{КРАВЧЕНКО Татьяна Константиновна -}

доктор экономических наук, профессор, заведующая кафедрой бизнес-аналитики, Национальный исследовательский университет «Высшая школа экономики»

\section{КУЗНЕЦОВ Сергей Олегович -}

доктор физико-математических наук, профессор, руководитель департамента анализа данных и искусственного интеллекта, Национальный исследовательский университет «Высшая школа экономики»

ЛУГАЧЕВ Михаил Иванович -

доктор экономических наук, профессор, заведующий кафедрой экономической информатики, Московский государственный университет им. М.В. Ломоносова

\section{МАЛЬЦЕВА Светлана Валентиновна -}

доктор технических наук, профессор, заведующая кафедрой инноваций и бизнеса в сфере информационных технологий,

Национальный исследовательский университет

«Высшая школа экономики»

\section{МЕЙОР Питер -}

$\mathrm{PhD}$, заместитель директора консультативной группы по радиокоммуникациям, Международный телекоммуникационный союз (ITU), заместитель руководителя Комиссии ООН по науке и технологиям, Женева, Швейцария

\section{МИРКИН Борис Григорьевич -}

доктор технических наук, профессор департамента анализа данных и искусственного интеллекта, Национальный исследовательский университет «Высшая школа экономики»

\section{МОТТЛЬ Вадим Вячеславович -}

доктор технических наук, профессор кафедры информационной безопасности, Тульский государственный университет

ПАЛЬЧУНОВ Дмитрий Евгеньевич -

доктор физико-математических наук, заведуюший кафедрой общей информатики, Новосибирский государственный университет

\section{ПАРДАЛОС Панайот (Панос) -}

$\mathrm{PhD}$, почетный профессор, директор центра прикладной оптимизации, департамент промышленной и системной инженерии, Университет Флориды, США

\section{СИЛАНТБЕВ Альберт Юрьевич -}

доктор технических наук, профессор кафедры информационных бизнес систем, Национальный исследовательский

технологический университет «МИСиС»

\section{ТАРАТУХИН Виктор Владимирович -}

кандидат технических наук, $\mathrm{PhD}$, руководитель научной группы Европейского исследовательского центра в области информационных систем (ERCIS) Мюнстерского университета, Мюнстер, Германия

\section{УЛЬЯНОВ Михаил Васильевич -}

доктор технических наук, профессор департамента программной инженерии, Национальный исследовательский университет «Высшая школа экономики» 


\title{
Spin-off design as an organizational practice: A methodological approach
}

\author{
Luigi Fici \\ Full Professor, Department of Economics and Enterprise \\ University of Tuscia \\ Address: Via del Paradiso, 47, Viterbo, 01100, Italy \\ E-mail:fici@unitus.it
}

\section{Pavel V. Malyzhenkov}

Associate Professor, Department of Information Systems and Technologies

National Research University Higher School of Economics

Address: 25/12, Bolshaya Pecherskaya Street, Nizhniy Novgorod, 603155, Russian Federation

E-mail:pmalyzhenkov@hse.ru

\section{Michela Piccarozzi}

Researcher, Department of Economics and Enterprise

University of Tuscia

Address: Via del Paradiso, 47, Viterbo, 01100, Italy

E-mail: piccarozzi@unitus.it

\section{Ekaterina S. Meleshina}

$M B A$, Account Manager Specialty Polyolefins

LyondellBasell Company

Address: 10 build.1, Uspensky Pereulok, Moscow, 127006, Russian Federation

E-mail: ekaterina.meleshina@lyondbasell.com

\begin{abstract}
Marketing the results of research carried out within publicly funded scientific institutions (universities, laboratories, research centers, etc.) is widely considered by decision-makers as a sustainable base for developing and stimulating business growth. Experience shows that small, innovative enterprises split off from big industries or academic bodies are the element that links together research and the business environment; their creation process represents a perfect field for applying the Enterprise Engineering apparatus. Such enterprises can assume the risk of transforming an entrepreneurial idea into industrial prototypes without which it is impossible to evaluate the commercial potential of research results. This mechanism is implemented via spin-off companies.

This paper focuses its analysis on the creation of academic spin-offs as one of the most widespread ways to bring research results to the market place, and also represents a powerful instrument of their internationalization strategy for universities. The main aim of the work is to identify the main elements raised by the creation of such companies, from the point of view of both public and academic authorities. The article proposes to consider key properties of university and industrial spin-offs as business units with flexible organizational form in tight connection with the formal modeling approach of the Enterprise Ontology and DEMO methodology, which are based on the Language-Action Perspective. For the analysis, the authors apply the concept of the transactions mechanism and a particular enterprise design methodology. As a result of the research, the paper proposes the main elements of a spin-off reference model constructed using the DEMO methodology means and it describes future directions of this work.
\end{abstract}

Key words: flexible organizational forms, collaborative strategy, transaction costs theory, spin-off, technology transfer, DEMO methodology, Language-Action Perspective.

Citation: Fici L., Malyzhenkov P.V., Piccarozzi M., Meleshina E.S. (2016) Spin-off design as an organizational practice: A methodological approach. Business Informatics, no. 3 (37), pp. 7-14.

DOI: 10.17323/1998-0663.2016.3.7.14. 


\section{Introduction}

I $\mathrm{n}$ the midst of the world economic crisis, one of the challenges frequently encountered by enterprises is cost reduction and, hence, the need for optimized organizational structures making businesses flexible. By flexibility we understand the capability of the enterprise to adapt rapidly their organizational structures to external or internal environmental changes. Consequently, the organizational structure itself must have suitable adaptation characteristics.

The present article details the methods of selecting suitable organization forms, and offers new principles of combining transaction costs theory and modern methods of business modeling based on the language action perspective. In particular, this paper addresses a research question about the applicability of Design and Engineering for Modern Organizations (DEMO) methodology [1] and we demonstrate that transaction analysis is the basis for decision support in DEMO applied to spinoff organizational choices.

The paper is structured as follows: after the introduction, part 1 analyzes the theoretical basis of organizational structure choice - the transactional costs. Part 2 provides a description of industrial and university spinoffs as a widespread flexible organizational form and introduces the DEMO methodology. Part 3 describes and provides new results linked to the choice of spin-offs' problem areas to which the DEMO can be applied. Part 4 formulates questions for future research and concludes the paper.

\section{The transactional approach and its influence on organizational structures}

Transaction analysis [2-8] may lead to the adoption of quite different organizational solutions. One is represented by spin-offs, which are referred to as flexible structures because they can rapidly redesign their organizational aspect as a response to changes in the external environment. In addition, organizational restructuring has a large social aspect. Therefore, the communication paradigms, patterns and policies used should be presented for decision makers explicitly during that process [9].

In studies influenced by the institutional theory, collaborations and networks encompass a broad range of inter-organizational relationships. Some authors $[3,10]$ have argued that institutions supply rules and resources upon which collaboration is built. Thus, to fully understand and explore the dynamics of different types of collaboration, alliances and networks, it is crucial to examine the institutionalized patterns of rules and routines, emphasizing the objective and the external aspects of the institutional environment.

The characteristics of the national innovation system of many European countries explain the serious impact of the economic crisis on innovation [11, 12]. Policy responses were concerned with supporting innovation systems and developing innovation capacity, such as improving infrastructure, public investments in $R \& D$ and innovation, investment in education and training at all levels, as well as demand-oriented innovation policies, including public procurement, financial support to SMEs, venture capital and, an important factor, policies aimed at the development of enterprise agglomerations. They are seen as part of the national strategy for coping with the effect of the financial crisis in many countries, partly because the industries involved in such programs represent industries oriented towards global markets that were most affected by the crisis.

International experience shows that it is small, innovative enterprises splitting off from big industry or from a university that represent the element linking together research and the business environment. Such a setting demonstrates that spin-offs serve as a perfect application field for the Enterprise Engineering apparatus [1, 13]. They can assume the risk of transforming a business idea into the introduction of industrial prototypes without which it is impossible to evaluate how promising the research idea will be on the market and whether it is worth commercial realization. This mechanism is implemented via spin-off companies.

\section{Spin-off as a flexible organizational form: Mechanisms of functioning and international experience}

Business forms like spin-offs offer various advantages. First of all, the strong socio-cultural link to a limited area promotes rapid circulation of ideas and an easy interaction between individuals who share a certain "cultural zone". It is based not only on the sharing of technical and production skills conveyed also through specific channels of training, but it includes as well a high entrepreneurial culture and better identification of the values and mutual interests of partners.

A second growth factor is the existence of a systemic approach in inter-business relations, that all the mentioned forms present, according to the logic of flexible specialization. The split nature of organizational structures often comes not from specific design patterns guided by a chief manager or head enterprises, but as a spontaneous response to the competitive environment. 
Thus, one ensures the possibility of replacing a company with others which are able to perform the same activities along the production process. At the same time, there is a remarkable stability of relationships, often based on a relationship of mutual trust which can facilitate the search for forms of coordination that increase the overall efficiency of the business scheme [4, 14].

Universities and other research institutions have always given more emphasis to technology transfer mechanisms to establish cooperation between university research and industry. Although very different in terms of methods and purposes, these alliances have often proved a success for both industry, which gains in competitiveness and technological advancement, and the university, which has the ability to use the abundant intellectual property available to it to finance its research and train its students by making them more competitive and prepared for the industrial world.

Spin-offs are exceptionally important in the topic of academic entrepreneurship. Spin-offs are more likely to develop basic research technologies that are not favored by established companies due to its lower profitability or which lack a readily available market. Through spinoffs, the gap between university research and industrial commercialization may be reduced. Furthermore, spinoffs also bring social and economic advantages, including employment creation, especially for highly-educated graduates and they strengthen the local economy.

Thus, spin-off means the creation of a new business unit by people who abandon their previous activity carried out within an already existing company or other institution (e.g. universities, research laboratories, etc.).

There are two aspects that characterize a spin-off:

$\downarrow$ support for the founders of the new enterprise;

$\checkmark$ the process by which a spin-off is created.

So, the essence of a spin-off is to help an aspiring entrepreneur to transform an idea, a potentiality, a production, technological or market opportunity that someone else does not want or cannot use in commercial terms into a new company.

The spin-off typology includes two different types:

$\diamond$ industrial spin-off;

$\diamond$ university spin-off (USO).

The first type is an enterprise generated from a preexisting one; as distinct from the USO which constitutes the subject matter of the present analysis and is an enterprise established by a group of researchers, professors or $\mathrm{PhD}$ students. An USO is a start-up company formed on the basis of the formal transfer of intellectual proper- ty rights from the university, and in which the university holds an equity stake $[15,16]$.

Thus, USOs can strengthen the relationships between universities and companies to improve knowledge transfer and achieve competitive advantages.

In France, Mustar [17] analyzed 200 cases of USOs and highlighted how the success of those companies depended on their ability to establish links with a variety of participants (research lab, clients, other companies and financial institutions). In Sweden or in Scotland [18], USOs are small companies, with only a few of them showing relative growth prospects. The most relevant USO cases originated in the USA [19, 20].

Universities in the USA are more structured and organized to create new companies. Therefore, researchers, $\mathrm{PhD}$ students and professors who want to improve commercial activity based on their research results can count on incubators, science parks, etc. In Italy, USOs are often rapidly growing small companies with not many employees.

The first category relates to the structure of USOs. USOs are often small because the proponents do not really analyze and define the relationship between the participants who will operate in the company. This implies an unclear definition of roles and lack of responsibility, which may give rise to problems, particularly when it comes to clients or trying to obtain financing. Furthermore, founding a university spin-off is a dynamic process developed in a highly complex environment. It involves numerous interactions within the university and with the external environment which may be subtle enough to be easily pointed out. Time lag may also occur between action and result, adding complexity to the process, especially regarding consequences of one policy. These problems can be successfully solved by applying Enterprise Engineering mechanisms, in particular, the DEMO methodology (part 3 of the present contribution).

Before analyzing the USOs' process, we need to describe the steps that a USO idea has to take in order to be approved (Italian experience [21-23]).

In the preliminary phase we can find three different promoters:

- USOs' Academic Commission;

- Academic Board of Governors;

- Academic Senate.

First of all, the Commission analyzes and selects all the USO proposals in order to determine which one could become a company, and whether the university will have an equity stake therein. 
Second, the Commission submits all ideas that completed the first step to both the Academic Board and the Academic Senate. They will finally approve only the most interesting ideas and enter these in the USO register. Lastly, the university prepares an academic convention with the approved USOs in which it regulates all details of the partnership, as well as the possibility for the USO's members to use the university's brand.

Hence, the USO's process comprises three phases:

$\downarrow$ pre-incubation phase;

$\checkmark$ incubation phase;

$\checkmark$ post-incubation phase.

During the pre-incubation phase, the focus is on organizing support activities and on all fundamental information required for the development of an action plan.

The incubation phase is the central step of the process and the most important one. In this phase the staff develops their activities based on the business plan, and the link between the USO and the university becomes strategic. Finally, in the post-incubation phase, the USO is ready to start its activities and to sell goods and services.

The most essential step is the central one because it involves business plan development. In this way, USOs can strengthen the relationships between universities and companies to improve knowledge transfer and achieve competitive advantages.

In Europe, attention given to this type of technology transfer is evident both in regional politics, that perceive USOs as an important mechanism of development of university-industry relations and creation of jobs and wealth, and in academic circles whose aim is to obtain the best results out of university research [12].

The significant increase we have witnessed in recent years in these realities is primarily due to the new role that universities are taking in the commercialization of their research activities or, in other words, to their new, more entrepreneurial approach.

Secondly, it is linked to the lack of stable tenured positions in universities, a factor that pushes researchersentrepreneurs to expand their possible range of activities beyond the mere academic role. Finally, it is important to stress that the increasing autonomy of universities will enable them to decide freely whether to endorse and support the development of USOs [24].

\section{Spin-off design: A methodological proposal on the DEMO base}

We wish to study the phenomenon of spin-off from the enterprise engineering point of view and here the
DEMO (Design \& Engineering Methodology for Organizations) represents a valid support. It is a methodology for the design, engineering, and implementation of organizations and networks of organizations. Entering into commitments and complying with them is the operational principle for each organization. These commitments are established in the communication between social individuals, i.e. human beings $[1,4,25,26]$.

Thus, as was mentioned before, in the case of creating a university spin-off the main actors are USO's Academic Commision, Academic Board of Governors and Academic Senate. Basic transactions can be composed to account for complex transactions. The DEMO methodology gives the analyst an understanding of the business processes of the organization, as well as the agents involved. Analysis of models built on the methodology of DEMO allows the company to obtain detailed understanding of the processes of governance and cooperation and serves as a basis for business reengineering and information infrastructure development consistent with business requirements. Figure 1 demonstrates a basic pattern of transaction as a single communication act between different actors.

In this figure "rq", "pm", "st" and "ac" mean different coordination acts and facts of a single transaction "request", "promise", "state" and "accept" while the grey box and diamond represent a production act and fact. The transaction itself evolves in three phases: the order phase (O-phase), the execution phase (E-phase), and the result phase (R-phase).

Another element useful to apply the DEMO methodology is the Transaction Result Table (Table 1).

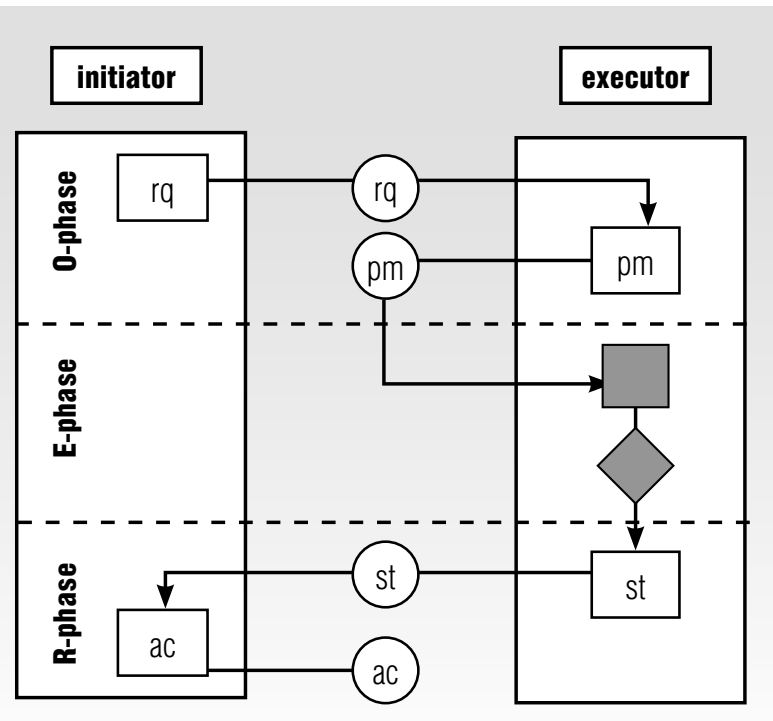

Fig. 1. The basic pattern of a transaction adopted from [1] 
The Transaction Result Table of university spin-off creation

\begin{tabular}{c|c}
\hline Transaction type & Result type \\
\hline T01 USO's proposal registration & USO's registration has been started \\
\hline T02 USO's approval & USO has been approved \\
\hline T03 USO's start & USO has been started \\
\hline
\end{tabular}

All elements listed above represent a base for ontological model creation using the DEMO methodology. It consists of four following models:

1. the Construction Model (CM) which specifies the identified transaction types and the associated actor roles, as well as the information links between the actor roles and the information banks;

2. the Process Model (PM) which contains, for every transaction type in the $\mathrm{CM}$, the specific transaction pattern of the transaction type;

3. the Action Model (AM) which specifies the action rules that serve as guidelines for the actors in dealing with their agenda;

4. the State Model (SM) specifies the object classes and fact types, the result types, and the ontological coexistence rules [1].

Below we present one element of the Construction model, the Actor-Transaction Diagram. It expresses the main initiators and executors (CA) of the transactions individuated in the Transaction Result Table (Figure 2).

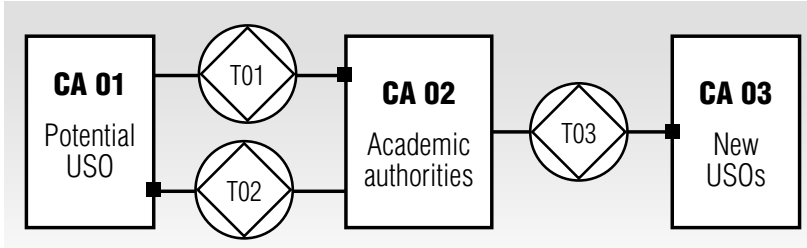

Fig. 2. Actor-Transaction Diagram

Such a setting has its practical applications. In the University of Tuscia in Viterbo, the process of creating spin-offs started thanks to a project carried out in cooperation with the local Chamber of Commerce and aimed at stimulating the creation of new companies capable of performing the entire cycle of activities: from carrying on research up to marketing and selling the results [23]. This project led to creation of university spin-offs in various business sectors like forestry and agro-environmental inventory (BioforItaly Ltd.), renewable energy and biomass (Sea Tuscia Ltd.), paper production (Tusciazyme Ltd.), consultancy services for archives management and organization (Tecnelab Ltd.) and others.
All these initiatives followed in the preliminary phase the scheme described above and the same actors were involved. From this point of view, the ontological approach expressed by means of DEMO methodology [1] represents a conceptual model that only shows the essence of an enterprise or a business process and is coherent (it constitutes a logical and truly integral whole), comprehensive (all relevant issues are covered), consistent (the aspect models are free from contradictions or irregularities) and concise (no superfluous matters are contained in it). These properties allow it to reduce the design costs and can be applied to the modelling of spinoff activity in its operative phase as well.

Thus, analysis of DEMO models provides decision makers with particular means of organizational transformations and the best strategy of splitting enterprises. Such choice unavoidably deals with information systems management and from such positions the use of the DEMO methodology for both enterprise structure modeling and individuation of the most suitable information system use is quite advantageous. DEMO is easily reproducible, and it can be applied regardless of the business segment of the enterprise, all of which is extremely important in the case of university spin-offs operating, as we've seen in the University of Tuscia case, in very different fields. In addition, the majority of SMEs adopt advanced information technologies such as electronic data interchange (EDI), enterprise resource planning (ERP) and e-commerce with the objective of improving their own supply chain efficiency first and then the supply chain of their partners.

\section{Conclusion}

Market and learning-oriented SMEs (like USOs, the subject of the present work) under strong competitive conditions tend to be more innovative both in management and organizational techniques. Progressing in information technologies and information systems, entrepreneurs and academic authorities are interested in developing a virtual enterprise with suitable strategic alliances that are based on research competencies.

We have demonstrated how DEMO transactions facilitate comprehensive analysis of different weak points of processes and, hence, the possibility to apply it to spin-offs. In comparison with other prevalent qualitative approaches like the Delphi method, panels or expert evaluation which have as their main weakness subjectivity, our proposal uses quantitative metrics to evaluate enterprise restructuring and future operational costs. This leads to better understanding by enterprise stakeholders and more accurate and objective planning of changes. 
Our analysis delivers the main elements for a reference model of creating spin-offs. This technique may be applied both to industrial and academic spin-offs and the direction of future research may be found in the specifications of actor roles and transactions specific for each type of spin-off. In this way, the DEMO methodology could cover the entire field of spin-off analysis. In addition, from the economic point of view the described solution provides an opportunity for the most efficient control of organizational costs.

\section{References}

1. Dietz J.L.G. (2006) Enterprise ontology: Theory and methodology. Berlin, Heidelberg: Springer-Verlag.

2. Cardoni A. (2012) Business planning and management accounting in strategic networks: Theoretical development and empirical evidence from enterprises' network "agreement". Management Control, no. 3, pp. 91-116.

3. Johanson M., Lundberg H. (2011) Network strategies for regional growth. London: Palgrave MacMillan.

4. Malyzhenkov P.V., Babkina T.S., Sergeev A.I. (2014) Flexible organizational forms design based on a transaction approach. Business Informatics, no. 4 (30), pp. 53-62.

5. Sampson R. (2004) Organizational choice in R\&D alliances: Knowledge-based and transaction cost perspectives. Managerial and Decision Economics, vol. 25, no. 6-7, pp. 421-436.

6. Williamson O.E. (1975) Markets and hierarchies. Analysis and antitrust implications. New York: Free Press

7. Williamson O.E. (2008) Outsourcing: Transaction cost economics and supply chain management. Journal of Supply Chain Management, vol. 44 , no. 2, pp. 5-16.

8. Williamson O.E., Winter S.G. (1991) The nature of the firm. Origins, evolution and development. Oxford: Oxford University Press.

9. Porter M.E. (1998) The competitive advantage of nations. New York: Free Press.

10. Antonioli D., Mazzanti M., Pini P. (2010) Productivity, innovation strategies and industrial relations in SME. Empirical evidence for a local manufacturing system in Northern Italy. International Review of Applied Economics, no. 24 (4), pp. 453-482.

11. European Commission (2010) Europe 2020 Strategy Paper. Brussels: European Commission.

12. European Commission (2002) European Trend Chart on Innovation. Brussels: European Commission.

13. Hoogervorst J.A.P. (2009) Enterprise governance and enterprise engineering. Berlin, Heidelberg: Springer-Verlag.

14. Wright M., Lockett A., Clarysse B., Binks M. (2006) University spin-out companies and venture capital. Research Policy, no. 35, pp. 481501 .

15. Degroof J.J, Roberts E.B. (2004) Overcoming weak entrepreneurial infrastructures for academic spin-off ventures. The Journal of Technology Transfer, vol. 29, no. 3-4, pp. 327-352.

16. Stankiewicz R. (1994) Spin-off companies from universities. Science and Public Policy, vol. 21, no. 2, pp. 99-107.

17. Mustar P. (1997) How French academics create hi-tech companies: The conditions for success or failure. Science and Public Policy, vol. 24, no. 1, pp. 37-43.

18. Gabrielsson J., Morten H. (2004) Context, behavior, and evolution: Challenges in research on Boards and Governance. International Studies of Management and Organization, vol. 34, no. 2, pp. 11-36.

19. O'Shea R.P., Chugh H., Allen T.J. (2008) Determinants and consequences of university spinoff activity: A conceptual framework. The Journal of Technology Transfer, no. 33, pp. 653-666.

20. Parkhe A. (2003) Institutional environments, institutional change and international alliances. Journal of International Management, no. 9, pp. 305-316.

21. Chiesa V., Piccaluga A. (2000) Exploitation and diffusion of public research: The case of academic spin-offs companies in Italy. $R \& D M a n-$ agement, vol. 30, no. 4, pp. 329-340.

22. Fici L., Piccarozzi M. (2011) University spin-offs, venture capital and public funds: A network for the creation of value. History of Accounting, Business Administration Doctrines and Development of New Methods of Management in Italy and in Russia. IV International Workshop (Nizhni Novgorod, Russia, 8-9 September 2010). Milano: RIREA, pp. 10-30.

23. Fici L., Piccarozzi M. (2010) Create value at the university: Financial and management problems in USOs. History of Accounting, Business Administration Doctrines and Development of New Methods of Management in Italy and in Russia. III International Workshop (Viterbo, Florence, Italy, 21-23 September 2009). Milano: RIREA, pp. 234-249.

24. Clarysse B., Moray N. (2004) A process study of entrepreneurial team formation: The case of a researched-based USOs. Journal of Business Venturing, no. 19, pp. 55-79.

25. Babkin E., Sergeev A. (2013) Towards developing a model-based decision support method for enterprise restructuring. Advances in Enterprise Engineering IV: Springer Lecture Notes in Business Information Processing (LNBIP), no. 146, pp. 17-27.

26. Dumay M., Dietz J.L.G., Mulder J.B.F. (2005) Evaluation of DEMO and the Language-Action Perspective after 10 years of experience. The Language Action Perspective on Communication Modeling. 10th International Working Conference (Kiruna, Sweden, 19-20 June 2005), pp. 77-106. 


\section{Проектирование спин-оффов как организационная практика: Методологический подход}

\section{Л. Фичи}

профессор департамента экономики и предприятия

Университет Тушии (Витербо, Италия)

Adpec: Via del Paradiso, 47, Viterbo, 01100, Italy

E-mail:fici@unitus.it

\section{П.В. Малыженков}

кандидат экономических наук, $P h D$

доцент кафедры информационных систем и технологий

Национальный исследовательский университет «Высшая школа экономики»

Адрес: 603155, г. Нижний Новгород, ул. Б. Печерская, д. 25/12

E-mail:pmalyzhenkov@hse.ru

\section{М. Пиккароцци}

исследователь департамента экономики и предприятия

Университет Тушии (Витербо, Италия)

Adpec: Via del Paradiso, 47, Viterbo, 01100, Italy

E-mail:piccarozzi@unitus.it

\section{Е.С. Мелешина}

$M B A$, менеджер по учету

компания LyondellBasell

Адрес: 127006, г. Москва, Успенский переулок, д. 10-б, стр. 1

E-mail: ekaterina.meleshina@lyondbasell.com

\section{Аннотация}

Проблема коммерциализации результатов научных исследований, реализованных в общественных исследовательских институтах (университетах, лабораториях, исследовательских центрах и т.д.), широко признана лицами, принимающими решения, как устойчивая база для развития и стимулирования роста бизнеса. Практика показывает, что малые инновационные предприятия, отделяющиеся от крупных компаний или академических учреждений, являются связующим элементом между научными исследованиями и бизнессредой, а процесс их создания представляет собой идеальное поле для применения аппарата инженерии предприятий. Такие предприятия могут принимать на себя риск преобразования предпринимательской идеи в промышленные прототипы, без которых невозможно оценить коммерческий потенциал результатов научных исследований. Этот механизм реализуется с помощью создания спин-оффов.

В настоящей статье анализируется создание академических спин-оффов как одного из наиболее распространенных способов размещения на рынке результатов научных исследований, также представляющего собой мощный инструмент интернационализации университетов. Главной целью работы является определение основных элементов, возникающих при создании таких компаний, с точки зрения как общественных, так и академических органов управления. В статье рассматриваются ключевые свойства академических и промышленных спин-оффов как бизнес-единиц с гибкой организационной формой, в тесной связи с формальным подходом моделирования онтологии предприятия и методологии DEMO, которые основаны на перспективе «язык-действие». Для анализа авторы прибегают к концепции трансакционного механизма и особой методологии проектирования. В качестве результата исследования предлагаются основные элементы построения референтной модели спин-оффа с использованием методологии DEMO, a также описываются направления дальнейшей работы.

Ключевые слова: гибкие организационные формы, стратегия сотрудничества, теория трансакционных издержек, спин-офф, технологический трансфер, методология DEMO, перспектива «язык-действие».

Citation: Fici L., Malyzhenkov P.V., Piccarozzi M., Meleshina E.S. Spin-off design as an organizational practice: A methodological approach // Business Informatics. 2016. No. 3 (37). P. 7-14.

DOI: $10.17323 / 1998-0663.2016 .3 .7 .14$ 


\section{Литература}

1. Dietz J.L.G. Enterprise ontology: Theory and methodology. Berlin, Heidelberg: Springer-Verlag, 2006.

2. Cardoni A. Business planning and management accounting in strategic networks: Theoretical development and empirical evidence from enterprises' network "agreement" // Management Control. 2012. No. 3. P. 91-116.

3. Johanson M., Lundberg H. Network strategies for regional growth. London: Palgrave MacMillan, 2011.

4. Malyzhenkov P.V., Babkina T.S., Sergeev A.I. Flexible organizational forms design based on a transaction approach // Business Informatics. 2014. No. 4 (30). P. 53-62.

5. Sampson R. Organizational choice in R\&D alliances: Knowledge-based and transaction cost perspectives // Managerial and Decision Economics. 2004. Vol. 25. No. 6-7. P. 421-436.

6. Williamson O.E. Markets and hierarchies. Analysis and antitrust implications. New York: Free Press, 1975.

7. Williamson O.E. Outsourcing: Transaction cost economics and supply chain management // Journal of Supply Chain Management. 2008. Vol. 44. No. 2. P. 5-16.

8. Williamson O.E., Winter S.G. The nature of the firm. Origins, evolution and development. Oxford: Oxford University Press, 1991.

9. Porter M.E. The competitive advantage of nations. New York: Free Press, 1998.

10. Antonioli D., Mazzanti M., Pini P. Productivity, innovation strategies and industrial relations in SME. Empirical evidence for a local manufacturing system in Northern Italy // International Review of Applied Economics. 2010. No. 24 (4). P. 453-482.

11. Europe 2020 Strategy Paper. Brussels: European Commission, 2010.

12. European Trend Chart on Innovation. Brussels: European Commission, 2002.

13. Hoogervorst J.A.P. Enterprise governance and enterprise engineering. Berlin, Heidelberg: Springer-Verlag, 2009.

14. Wright M., Lockett A., Clarysse B., Binks M. University spin-out companies and venture capital // Research Policy. 2006. No. 35. P. 481501

15. Degroof J.J, Roberts E.B. Overcoming weak entrepreneurial infrastructures for academic spin-off ventures // The Journal of Technology Transfer. 2004. Vol. 29. No. 3-4. P. 327-352.

16. Stankiewicz R. Spin-off companies from universities // Science and Public Policy. 1994. Vol. 21. No. 2. P. 99-107.

17. Mustar P. How French academics create hi-tech companies: The conditions for success or failure // Science and Public Policy. 1997. Vol. 24. No. 1. P. 37-43.

18. Gabrielsson J., Morten H. Context, behavior, and evolution: Challenges in research on Boards and Governance // International Studies of Management and Organization. 2004. Vol. 34. No. 2. P. 11-36.

19. O'Shea R.P., Chugh H., Allen T.J. Determinants and consequences of university spinoff activity: A conceptual framework // The Journal of Technology Transfer. 2008. No. 33. P. 653-666.

20. Parkhe A. Institutional environments, institutional change and international alliances // Journal of International Management. 2003. No. 9. P. 305-316.

21. Chiesa V., Piccaluga A. Exploitation and diffusion of public research: The case of academic spin-offs companies in Italy // R\&D Management. 2000. Vol. 30. No. 4. P. 329-340.

22. Fici L., Piccarozzi M. University spin-offs, venture capital and public funds: A network for the creation of value // History of Accounting, Business Administration Doctrines and Development of New Methods of Management in Italy and in Russia. IV International Workshop (Nizhni Novgorod, Russia, 8-9 September 2010). Milano: RIREA, 2011. P. 10-30.

23. Fici L., Piccarozzi M. Create value at the university: Financial and management problems in USOs // History of Accounting, Business Administration Doctrines and Development of New Methods of Management in Italy and in Russia. III International Workshop (Viterbo, Florence, Italy, 21-23 September 2009). Milano: RIREA, 2010. P. 234-249.

24. Clarysse B., Moray N. A process study of entrepreneurial team formation: The case of a researched-based USOs // Journal of Business Venturing. 2004. No. 19. P. 55-79.

25. Babkin E., Sergeev A. Towards developing a model-based decision support method for enterprise restructuring // Advances in Enterprise Engineering IV: Springer Lecture Notes in Business Information Processing (LNBIP). 2013. No. 146. P. 17-27.

26. Dumay M., Dietz J.L.G., Mulder J.B.F. Evaluation of DEMO and the Language-Action Perspective after 10 years of experience // The Language Action Perspective on Communication Modeling. 10th International Working Conference (Kiruna, Sweden, 19-20 June 2005). P. $77-106$. 


\title{
Application of the Eclipse EMF technology for multifaceted organization modelling
}

\author{
Eduard A. Babkin \\ Professor, Department of Information Systems and Technology \\ National Research University Higher School of Economics \\ Address: 25/12, Bolshaya Pecherskaya Street, Nizhny Novgorod, 603155, Russian Federation \\ E-mail:eababkin@hse.ru

\section{Oksana V. Radzinskaya} \\ Lecturer, Department of Information Systems and Technology \\ National Research University Higher School of Economics \\ Address: 25/12, Bolshaya Pecherskaya Street, Nizhny Novgorod, 603155, Russian Federation \\ E-mail: oradzinskaya@hse.ru
}

Abstract

This research paper explores the most developed methodologies used for multifaceted modeling of organizational structures. It is asserted that the existing methodologies (DEMO - Design and Engineering Methodology for Organizations, BORM - Business Object Relation Modeling and OntoUML) provide tools for analysis of the organization and its business processes through different ways. They lead to different results and make the process of organization modeling complicated. There is no software to support work with these methodologies together. The purpose of this research is to create a unified meta-model (within the Eclipse EMF technology) for a new methodology based on the existing ones and to analyze the completeness of these methodologies for describing enterprise architecture. It will serve as a basis for a new open software platform for multifaceted modeling of the organization.

In this research, we have compared the above-mentioned methodologies and concluded that despite the fact that these methodologies provide an analysis of different aspects of organizational structure, they have a common basic set of concepts. This study demonstrates the implementation of the Ecore model that is built on the basis of the selected group of common elements of these methodologies. We have also found that the combination of the considered methodologies contains all the concepts inherent in the systematic approach to the modeling of organizational structure. Furthermore, we have demonstrated the aspects of the organization that can be modeled by the methodologies considered. Using the Zachman framework, it was shown that: the DEMO, BORM and OntoUML methodologies allow us to describe in detail the business processes that take place at different levels of the organization, from the ontological to the datalogical, and therefore provide comprehensive information for the multifaceted modeling of an organization. However, none of the existing methodologies takes the time component and goal-setting into consideration.

Key words: multifaceted organization modeling, enterprise architecture, DEMO, BORM, OntoUML, unified methodology, Zachman framework, Eclipse EMF, systematic approach to the modeling of an organization.

Citation: Babkin E.A., Radzinskaya O.V. (2016) Application of the Eclipse EMF technology for multifaceted organization modelling. Business Informatics, no. 3 (37), pp. 15-29. DOI: 10.17323/1998-0663.2016.3.15.29.

\section{Introduction}

B ackground of the study. The process of enterprise modeling is highly complicated. At present, there are many different approaches for modeling an organizational structure, for example, ARIS,
UML, IDEF, PICTURE [1], which are flexible enough to perform modeling in various areas but insufficient to cover all the aspects. That is why our research focuses on studying the DEMO [2], BORM [3] and OntoUML [4] methodologies, which are more suitable for multifac- 
eted modeling of the organization and business process analysis.

When reviewing the literature, it became apparent that each of these three methodologies has a lot of advantages. For instance, the main contribution of DEMO is to provide the essential model of an organization using several diagramming techniques. The DEMO methodology makes it possible to abstract from the informational, documentary and organizational realization, while the BORM approach is easier for understanding by those who are unfamiliar with notation. Moreover, the existing methodologies allow us to perform an analysis of different areas of organizational structure, thereby giving different recommendations. An additional point is that there are many practical examples showing that the structure and processes of organization continue to be described using different notations and techniques [1]. However, all the notations used are based on a number of basic concepts that can be reused and interpreted in accordance with other notations and methodologies. In the framework of this study, the DEMO methodology was taken as a basic concept. The reason is that the DEMO has the strongest methodological justification and there are many examples demonstrating the successful and efficient use of the DEMO in practice. However, using this methodology alone is insufficient to solve a number of problems. To overcome these limitations we decided to use the concepts of other models and notations that are also popular in practice - BORM and OntoUML.

While the debate over these methodologies seems to gain popularity, one of the main issues remains unresolved. Today there are a lot of tools that support different methodologies, but none of these tools provides a platform for multifaceted modeling of organizations combining the DEMO, BORM and OntoUML methodologies. That is why it seemed appropriate to introduce a new methodology developed on the basis of the three existing ones and create an object-oriented graphics editor.

Statement of the problem. The general purpose of this study is to create a unified meta-model for a new modeling methodology based on DEMO, BORM and OntoUML and to analyze the completeness of these methodologies for describing enterprise architecture. The present investigation focuses on determining the common principles of these methodologies, finding common objects and developing a meta-model, which will be used to create the final software product. It is important to note that our goal is not only to create a new unified meta-model, but also to generate an extension of this meta-model using Eclipse EMF [5] technology. This should be done in order to integrate the final software with other Eclipse projects and analyze the completeness of these methodologies within the Zachman framework [6].

In addition, this investigation should reveal some ontological drawbacks of the above-mentioned methodologies for analysis of business processes and attempt to overcome them.

Professional significance. In the framework of this work, our immediate goal was to create a unified metamodel for the DEMO, BORM and OntoUML methodologies using Eclipse EMF technology. In order to achieve this goal, the following specific tasks of further analysis should be performed:

$\downarrow$ exploring principles and objects of the DEMO, BORM and OntoUML methodologies, their advantages and disadvantages within Eclipse EMF technology;

$\checkmark$ identifying common principles and elements of these methodologies;

$\checkmark$ creating a unified meta-model based on the common principles and elements using Eclipse EMF technology;

$\checkmark$ analyzing the completeness of these methodologies for describing enterprise architecture within the Zachman framework.

The problem as stated is of great interest to people engaged in the process of organization modeling and dealing with issues of business processes analysis. Moreover, the research will contribute to development of a new approach for multifaceted modeling of organizational structures. At the same time, this study might be useful for many organizations which have taken the decision to modify their business processes.

In Section 1, we present a review of the literature on the subject. Section 2 offers a comparison of the existing methodologies. Section 3 presents the development of a common meta-model for the DEMO, BORM and OntoUML methodology. In Section 4 we assess the completeness of the DEMO, BORM and OntoUML methodologies for describing enterprise architecture within the Zachman framework. Section 5 presents the example - "Pizzeria" - to assess the possibilities of the existing methodologies. Finally, we summarize the work accomplished.

\section{Literature review}

The following review was made after studying a large body of literature on the subject. Since there are numer- 
ous methodologies that include the notion of "organization modeling" it seemed appropriate to define it in accordance with the most developed methodologies: DEMO, BORM and OntoUML. Most researchers take into account just the most elementary characteristics of these methodologies, but a few investigations have explained how these methodologies could be used for different systems.

Our theoretical review starts off with the explanation of the key definitions of the afore- mentioned methodologies.

DEMO, which stands for Design and Engineering Methodology for Organizations, is based on Enterprise Ontology, defined by J. Dietz (the author of this methodology) [2]. In turn, Enterprise Ontology is based on the theory of Communicative Action and the LanguageAction Perspective. According to J. Dietz, DEMO is a methodology for designing, modeling and engineering organizations, whose main contribution is to provide the essential model of an organization using several diagramming techniques, thereby abstracting from the informational, documentary and organizational realization (as defined by the DEMO theory) [7].

Numerous studies have demonstrated only the most elementary fundamentals including explanations of the basic definitions such as communication, information, action, organization as a part of the DEMO methodology and analysis of four axioms of the Enterprise Ontology theory, such as distinction, production, transaction and composition. However, information about the methods and diagrams of the DEMO methodology has been provided by only a few researchers, among one can namee $\mathrm{Ph}$. Huysmans, Kr. Ven and J. Verelst [8]. These authors applied the Actor Transaction Diagram (ATD) and Process Structure Diagram (PSD) to obtain abstracts and high-quality Open Source Software Development (OSSD) process models, but other diagrams were left beyond the scope of these research studies.

According to the afore-mentioned group of researchers, DEMO has a strong theoretical foundation and provides clear and unambiguous definitions for the constructs used in the various models. It gives clear guidelines on how and why abstractions can be made [7]. In other words, DEMO analyzes processes at the ontological level, studying the communication patterns between human actors, instead of the sequences in which activities are performed. Therefore, DEMO helps us to understand the process of organization modeling by providing a high-level and abstract view of the organization.
It is difficult to exaggerate the importance of the described methodology for the process of information systems development and Business Process Reengineering. However, the DEMO methodology is not devoid of some drawbacks, the most important of which concerns the understandability and extensibility of DEMO. In order to optimize the process of organization modeling, it would be appropriate to combine DEMO with other techniques and methodologies, such as BORM.

BORM, which stands for Business Object Relation Modeling, was developed in 1993. The theoretical foundation of this methodology is the theory of finite-state machines. Since 2000, R. Knott, V. Merunka and J. Polak [3] have published a significant number of works with the support of the Czech Academic link program of the British Council as a part of the VAPPIENS research project. According to them, BORM is a complex method for systems analysis and design; it utilizes an objectoriented paradigm in combination with business process modeling.

Many articles written by R. Knott, V. Merunka and J. Polak fully explain the basic definitions and principles of BORM, OBA (Object Behavior Analysis) and ORD (Object Related Diagram). Researchers realize that BORM differs from other business-oriented development methodologies. The difference is as follows: in BORM, all objects are defined as business objects. During the design process, these objects are changed into a conceptual object, and then during the implementation they are evolved into software objects. Thus, BORM requires that the degree of knowledge about an object is only what is required to enable the development process to proceed [9]. OBA is a step-by-step, iterative approach to analysis that helps you cross the conceptual gap between a description of the "real world" and the syntax of object-oriented modeling techniques. The result of OBA is a description of a model for the problem being analyzed. That is why this model is essential for object related diagrams (ORD).

R. Knott, V. Merunka and J. Polak point out that BORM has a lot of advantages. The most important is that the BORM approach is very easy and simple for understanding and it makes faster and better analysis of some business problems. However, its biggest disadvantage is a lack of formal foundations which are necessary for clear and precise definition of the structure and semantics of ORD. M. Podlouck'y and R. Pergl found this fact in their article "Towards Formal Foundations for BORM ORD Validation and Simulation" [10]. These researchers attempted to create formal foundations for BORM which would help not only in under- 
standing the semantics of BORM, but also in implementation of advanced software tools for this method. That is why the punch line of their article was to identify several flaws in the diagram's behavior semantics and to propose minor changes and enhancements for the model.

The researchers mentioned above have formulated their own theoretical principles named the "simultaneity" and "dependency principles" [10]. The "simultaneity principle" states that no participant can be split into multiple instances and thus perform several tasks in parallel. The "dependency principle" means that a task A may require another task to be completed before this task A can be completed. In order to realize these new principles, researchers have introduced the concepts of "input conditions" and "output conditions" [10]. The "input condition" is a Boolean expression, whose variables are the ending transitions in that state. The "output condition" is a Boolean expression, whose variables are the outgoing transitions from the given state. Their new definitions have had a significant influence on the development of the BORM methodology.

Talking about the process of organization modeling, it is essential to describe one more methodology, - OntoUML. OntoUML is a conceptual modeling language, whose meta-model was designed to comply with the ontological distinctions and axiomatization of foundational ontology [4]. It has been proposed as an extension of UML that incorporates in the UML 2.0 original metamodel a number of ontological distinctions and axioms put forth by the Unified Foundation Ontology (UFO). Many researchers in the field of Conceptual Modeling attempt to explain the basic concepts of this methodology and explore a number of patterns, which can show how OntoUML will be useful for analyzing business objects and some systems. Among these researchers, G. Guizzardi, A.P. Graças and R.S.S. Guizzardi wrote an article entitled "Design patterns and inductive modeling rules to support the construction of ontologically well-founded conceptual models in OntoUML" [11]. They attempted to explore an inductive strategy in the construction of OntoUML models. In their paper, the authors developed a number of design patterns and demonstrated how their strategy could reduce the complexity of the modeling process for the novice modeler. These patterns have had a great consequence for the OntoUML methodology and the process of business organization modeling in general.

To summarize, there are a considerable number of works investigating the basic concepts and principles of these three methodologies, demonstrating their advantages and drawbacks, providing new definitions and patterns. Notwithstanding the fact that these methodologies provide an analysis of different areas of the organizational structure, today there are no approaches combining the DEMO, BORM and OntoUML methodologies. In order to completely define the model of an organization, it is essential to combine these three methodologies, prepare a unified meta-model for existing methodologies and analyze the completeness of these methodologies for describing enterprise architecture within the Zachman framework.

\section{Comparison of the methodologies}

From the review above, it is appropriate to underline that these methodologies consider various aspects of an organization. For that reason, they are suitable for use in different sorts of situations. In order to solve operational problems which have no effect on the process as a whole, the BORM methodology is more useful, because only using BORM does it become clear which stage of the process had failed. When it is necessary to change the process of work in general affecting the ontological level of the organization, the DEMO methodology is more appropriate. When you need to provide a fundamental change in the process of work including staff changes, it is advisable to use the OntoUML methodology in addition to the DEMO methodology, because it analyzes the relationships and employee hierarchy. Since we consider an organization as a complex system, a complete analysis of the systematic approach is to be made. This means that the methodologies that we have taken as a basis should meet its basic principles [12]. That is why it is appropriate to identify the key concepts inherent in the methodologies in order to perform an analysis of the organization and to evaluate these methodologies for conformity to the identified principles and concepts. These concepts have been developed on the basis of the Levenchuk [13] study. The results are presented in Table 1 .

As we can see, these methodologies include almost all the concepts inherent in the systematic approach to the modeling of an organization and meet almost all requirements. But none of these methodologies embraces all of the concepts reviewed above. Thus, in order to overcome this drawback and provide a multifaceted analysis of the organization, it is appropriate to consider them together. 
Table 1.

The methodologies for relevant concepts of the systematic approach

\begin{tabular}{|c|c|c|c|}
\hline Goncepts & DEMO & BORM & OntoUML \\
\hline $\begin{array}{l}\text { Examination of the organization not only as a "black box", } \\
\text { but as a "white box" [5] }\end{array}$ & + & + & + \\
\hline $\begin{array}{l}\text { Examination of three levels of organizational structures: } \\
\text { human activities, the operation of computer programs, } \\
\text { supporting infrastructure for programs }\end{array}$ & $\begin{array}{l}+/- \\
\text { (does not examine the function- } \\
\text { ing of computer programs) }\end{array}$ & + & $\begin{array}{l}+/- \\
\text { (does not examine } \\
\text { the functioning of } \\
\text { computer programs) }\end{array}$ \\
\hline $\begin{array}{l}\text { Investigation of the activities of objects and actors, } \\
\text { processes and data, the functional components of programs } \\
\text { and IT equipment }\end{array}$ & $\begin{array}{l}+l- \\
\text { (does not analyze the functional } \\
\text { programs and IT equipment) }\end{array}$ & $\begin{array}{l}+/- \\
\text { (does not analyze } \\
\text { IT equipment) }\end{array}$ & $\begin{array}{l}+/- \\
\text { (does not analyze IT } \\
\text { equipment) }\end{array}$ \\
\hline $\begin{array}{l}\text { Exploration of answers to the questions: how to divide responsi- } \\
\text { bilities and authority between people and groups of people and } \\
\text { what practices (technology) are used within the enterprise }\end{array}$ & + & $\begin{array}{l}+/- \\
\text { (has no information about } \\
\text { employee hierarchy) }\end{array}$ & + \\
\hline Examination of the organization throughout its life cycle & + & + & - \\
\hline $\begin{array}{l}\text { Examination of the controlling, controlled subsystem, } \\
\text { as well as external systems }\end{array}$ & + & + & + \\
\hline
\end{tabular}

The analysis of comparisons allows us to understand that despite what these methodologies have in common, they consider different areas of the organizational structure. Exactly the combination of these two factors leads us to conclude that in order to completely describe the organization and provide its multifaceted modeling, it is appropriate to bring together these three methodologies on the basis of their common concepts, ideas and elements.

\section{The development of a common meta-model for the DEMO, BORM and OntoUML methodologies}

In order to create a common meta-model, it is advisable to use the Eclipse EMF technology. Eclipse EMF or Eclipse Modeling Framework is a basis of the Eclipse Modeling Project, that is one of the most promising platforms for developing tools for visual modeling using the Eclipse technology. EMF is a technology for code generation in order to create tools and other applications based on structured data diagrams of the model specification presented in XMI. In order to ensure the generation of a complete meta-model, it seems appropriate to use the Domain Model (*.ecore and *.ecore_diagram): a meta-model that defines all of the elements, attributes, relationships that are used in the model [5].

DEMO consists of 4 models that can be represented in the form of certain diagrams:

$\downarrow$ ATD and OCD corresponds to the Construction Model;

$\checkmark$ for Process Model, it is necessary to prepare a Process Structure Diagram;

$\checkmark$ for construction of the Action Model, it is a common practice to use Action Rule Specifications;

$\downarrow$ Object Fact Diagram is used for the State Model [11].

Exactly the ADT, OCD, OFD and PSD diagrams are reflected in the final meta-model. In the process of organizational modeling, it has been appropriate to stress that many objects are duplicated. This fact has helped to identify common elements and to create them once for reuse. Based on an analysis of the relationship between the diagrams, it has been extremely interesting to identify three types of common elements for which this possibility could be provided. These groups of elements are presented in Table 2.

Table 2.

General elements of the DEMO methodology

\begin{tabular}{|c|c|c|c|c|}
\hline General elements & ATD & PSD & OFD & OCD \\
\hline \multirow{2}{*}{ Actor } & Elementary Actor & \multirow{2}{*}{ Actor Boundary } & General 0bject & Elementary Actor \\
\hline & Composite Actor & & External Object & Composite Actor \\
\hline Transaction & Transaction & $\begin{array}{l}\text { Transaction Boundary and four steps: } \\
\text { Request (rq), Promise (pm), State (st), Accept (ac) }\end{array}$ & Result Fact & Transaction \\
\hline Boundary & Boundary & - & - & Sol \\
\hline
\end{tabular}




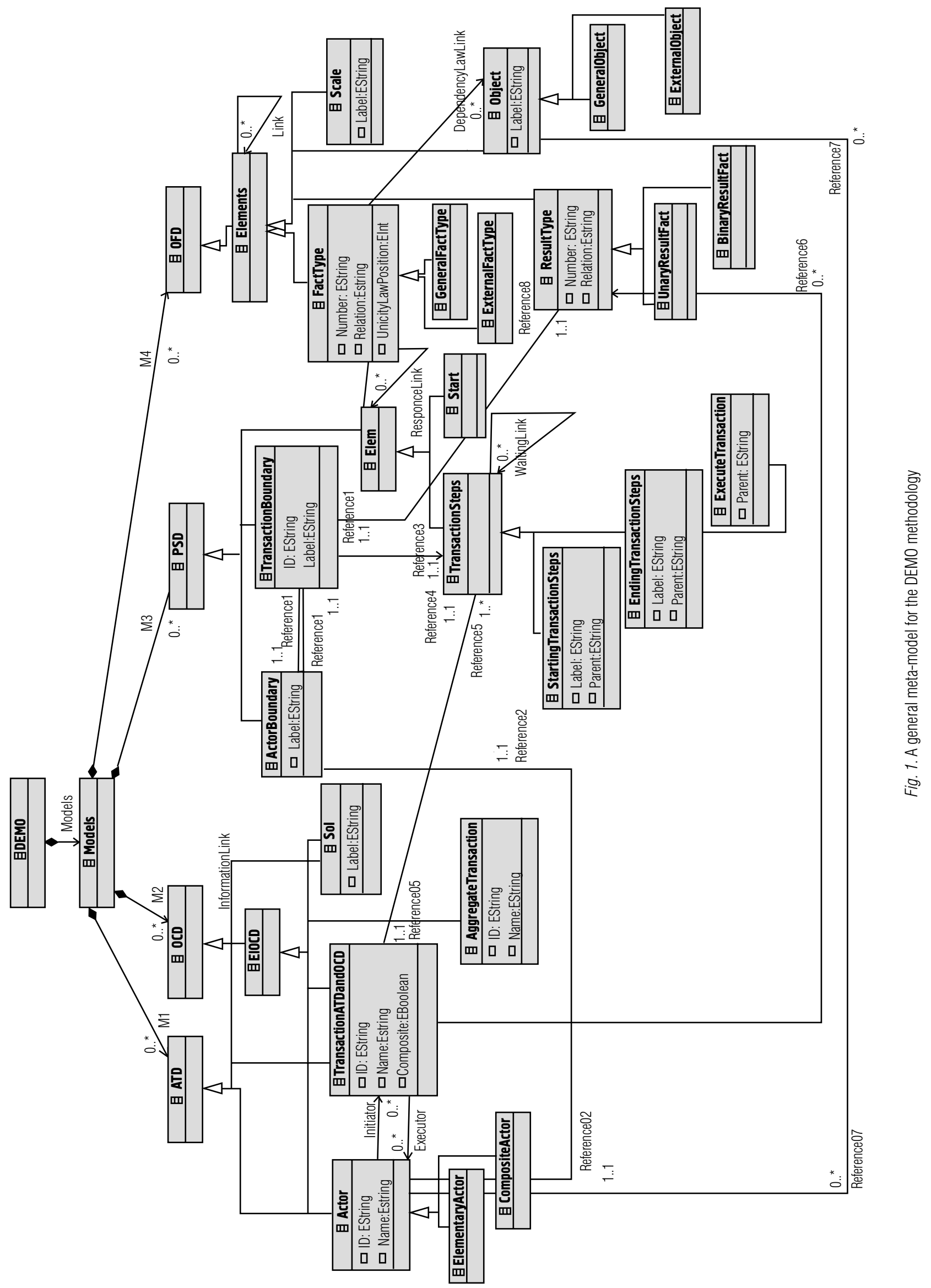




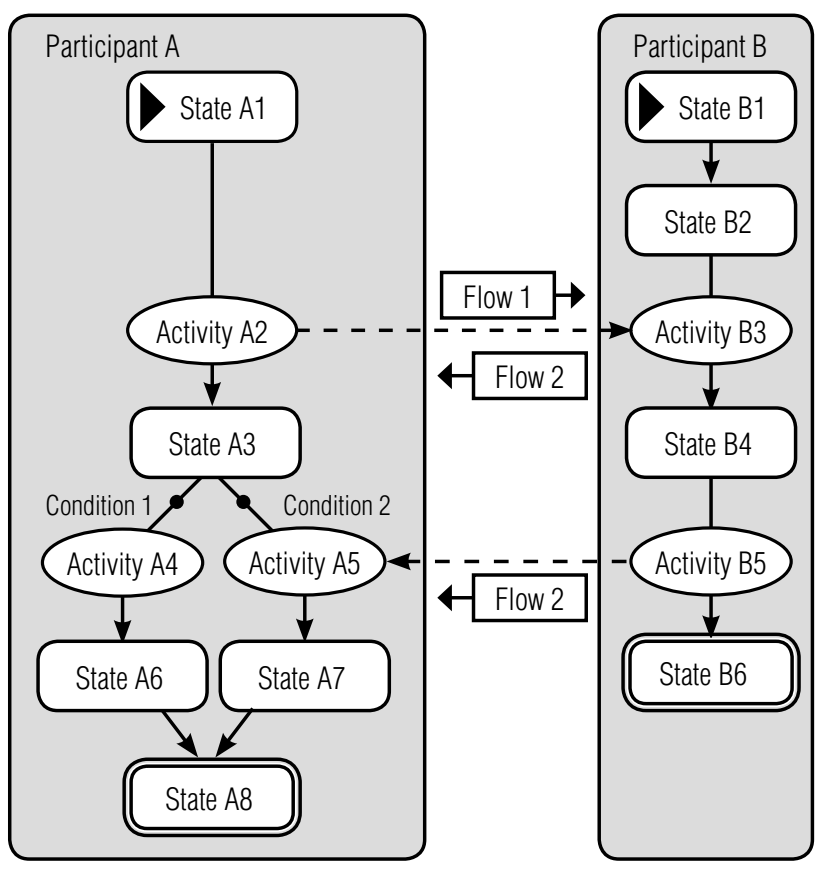

Fig. 2. Schematic representation of the ORD

Based on the identified groups of common elements, a common meta-model for the DEMO methodology has been constructed (Figure 1).

In the framework of this research, one more methodology, - BORM, - has been considered. For the BORM methodology, it has been accepted to allocate the basic elements of the Object Relational Diagram (ORD), such as [9] (Figure 2):

$\diamond$ participants - employees, organizations and systems involved in the process;

$\diamond$ states - intermediate phases;

$\diamond$ activities (transactions) - the channels representing interaction between users.

A general meta-model for the BORM methodology is presented in Figure 3.
For the OntoUML methodology. it has been essential to identify common objects, elements and connections for all three levels of methodology: UFO-a, UFO-b, UFO-c [14] (Figure 4).

Comparing the descriptions of these methodologies in order to construct a common meta-model, it has been appropriate to select four groups of general objects that have similar characteristics, attributes and functions in all three methodologies (Table 3).

Table 3.

\section{General elements of the DEMO, BORM and OntoUML methodologies}

\begin{tabular}{l|l|l|l}
\multicolumn{1}{c|}{$\begin{array}{c}\text { General } \\
\text { objects }\end{array}$} & \multicolumn{1}{c|}{ DEMO } & BORM & \multicolumn{1}{c}{ OntoUML } \\
\hline Actors & $\begin{array}{l}\text { ATD, OCD: Actors } \\
\text { PSD: Actor Boundary } \\
\text { OFD: Objects }\end{array}$ & Participants & $\begin{array}{l}\text { Universal } \\
\text { Object, excl. } \\
\text { Antirigid Sortal }\end{array}$ \\
\hline Transactions & $\begin{array}{l}\text { ATD, OCD: transaction, } \\
\text { PSD: Transaction Boundary } \\
\text { OFD: Unary/Binary Result }\end{array}$ & Actions & Action event \\
\hline Databases & $\begin{array}{l}\text { OCD: Aggregate } \\
\text { Transaction }\end{array}$ & - & Aspects \\
\hline States & OFD: Fact Type & States & Antirigid Sortal \\
\hline
\end{tabular}

On the basis of the selected groups, a final meta-model is presented in the following scheme:

- Level 1 - Entities: The total essence of all elements of the methodology;

- Level 2 - General objects: Four groups of shared objects described above;

- Level 3 - Methodologies: All the elements of the DEMO, BORM and OntoUML methodologies.

The common meta-model is constructed on the base of this scheme.

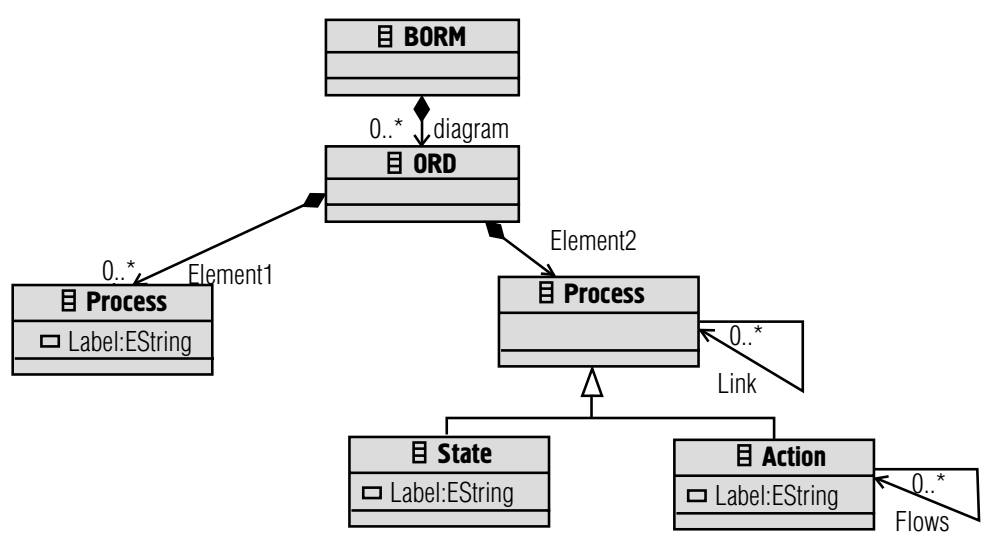

Fig. 3. A general meta-model for the BORM methodology 


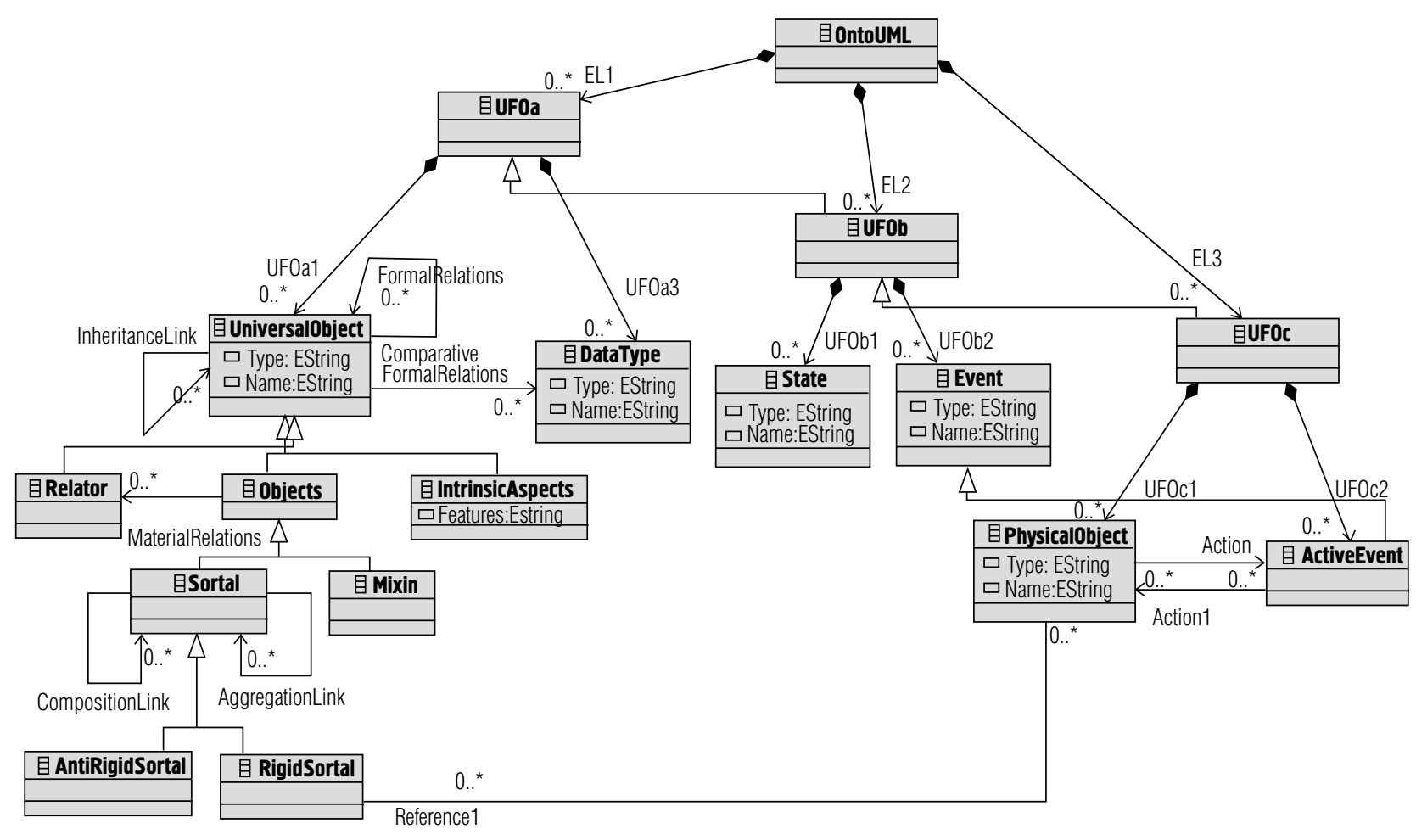

Fig. 4. A general meta-model for the OntoUML methodology

\section{An assessment of the completeness of the DEMO, BORM and OntoUML methodologies for describing enterprise architecture within the Zachman framework}

The above analysis shows that the set of the DEMO, BORM and OntoUML methodologies covers many areas and aspects of the organization. In order to clarify them, it was deemed best to use one of the most common tools - the Zachman framework [6]. The main objective of this model is a logical partition of the enterprise architecture into sections in order to consider the enterprise architecture with different levels of abstraction.

Since each of the cells of the Zachman framework describes an architecture or independent model that an organization might have, it was essential to make an attempt to relate each of them with at least one of the three investigated methodologies. The results of this correlation are shown in Table 4. In this table:

light-gray cells correspond to the OntoUML methodology;

$\downarrow$ dark-gray cells correspond to the BORM methodology;

$\downarrow$ vertically shaded cells correspond to the DEMO methodology;

$\downarrow$ white cells - without existing methodologies.
The results presented in Table 4 complement our findings above and identify a number of additional deficiencies:

$\checkmark$ the DEMO describes an organization as a system; that is why it can be used for the complete description of the System Representation Models;

$\diamond$ the set of the DEMO, BORM and OntoUML methodologies allows us to describe in detail the business processes of the organization at different levels, from the ontological to the datalogical;

$\checkmark$ none of the reviewed methodologies is intended to describe the program code and program implementation (Operations Instances);

$\diamond$ none of the reviewed methodologies takes the time component and goal-setting in the Scope Context and Business Concepts perspectives into consideration.

Thus, the set of the investigated methodologies:

- contains all the concepts inherent in the systematic approach to the modeling of organizational structure;

- allows us to provide a detailed analysis of the business processes of the organization, its objects and relationships;

- and thus provides information sufficient for multifaceted modeling of organizational structure. 


\section{Assessment of completeness of the DEMO, BORM and OntoUML methodologies \\ in the frame of the Zachman framework}

\begin{tabular}{|c|c|c|c|c|c|c|}
\hline & What? & How? & Where? & Who? & When? & Why? \\
\hline \multirow{2}{*}{ Business context planners } & BORM & \multirow{2}{*}{ DEMO } & \multirow{2}{*}{ OntoUML } & DEMO & & \\
\hline & OntoUML & & & OntoUML & & \\
\hline \multirow{2}{*}{ Business concept owners } & \multirow{2}{*}{ OntoUML } & \multirow{2}{*}{ DEMO } & OntoUML & DEMO & & \\
\hline & & & DEMO & OntoUML & & \\
\hline \multirow{3}{*}{ Business logic designers } & DEMO & DEMO & DEMO & DEMO & DEMO & DEMO \\
\hline & \multirow{2}{*}{ OntoUML } & \multirow{2}{*}{ BORM } & \multirow{2}{*}{ BORM } & OntoUML & \multirow{2}{*}{ BORM } & \multirow{2}{*}{ BORM } \\
\hline & & & & BORM & & \\
\hline \multirow{2}{*}{ Business physics builders } & \multirow{2}{*}{ OntoUML } & \multirow{2}{*}{ BORM } & \multirow{2}{*}{ BORM } & BORM & \multirow{2}{*}{ BORM } & DEMO \\
\hline & & & & OntoUML & & BORM \\
\hline $\begin{array}{c}\text { Business component } \\
\text { implementers }\end{array}$ & OntoUML & BORM & BORM & BORM & BORM & BORM \\
\hline The enterprise & OntoUML & BORM & BORM & BORM & & \\
\hline
\end{tabular}

However, these methodologies don't take the time component, goal-setting and description of program implementation into account. But the assessment of the transactions duration and the impact of a particular transaction on the business process in general is important to achieve the strategic goals of the organization. Hence, it is advisable to consider the possibility of combining the DEMO, BORM and OntoUML methodologies with other tools to overcome the shortcomings. BMM (Business Motivation Model) [15] can serve as an example of such tool. It combines elements of the objectives definition (mission, goals, vision, tactics, strategy), as well as elements of business - processes (Business Rules, Course of Action, Desirable Result), establishing a link between them. That is extremely helpful for the integration of this model with the investigated methodologies and for covering the sixth aspect of the Zachman framework (Figure 5).

However, as the Tables $1-3$ show, the set of the DEMO, BORM and OntoUML methodologies is enough for multifaceted modeling of organizational structure.

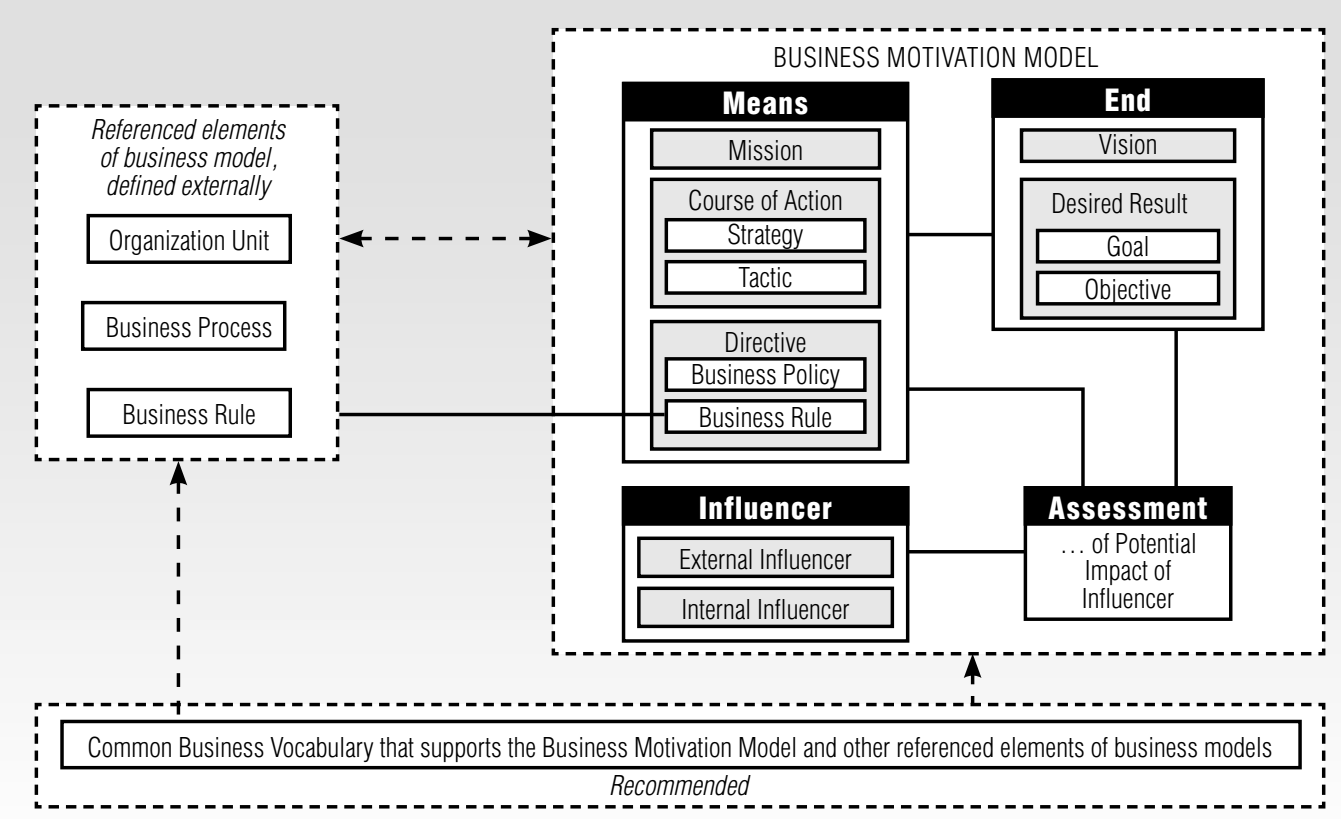

Fig. 5. The structure of BMM (Business Motivation Model) 


\section{Application of the DEMO, BORM and OntoUML methodologies}

In order to assess the possibilities of the existing methodologies, it is essential to consider a popular example of a "Pizzeria" such as was used by J. Dietz [2].

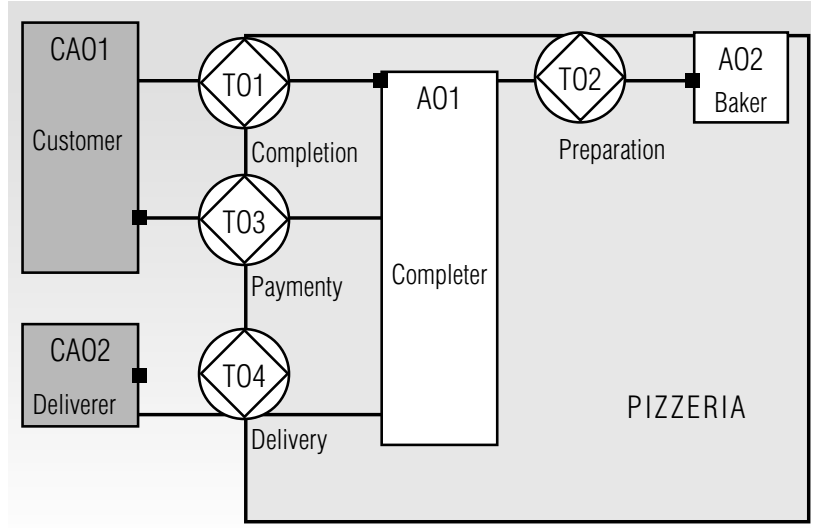

Fig. 6. The ATD diagram for the DEMO methodology (for the "Pizzeria")

Problem Statement: To order a pizza, the client needs to come into a pizzeria or make a phone call. In both cases, the manager writes down the name of the customer, the products ordered, the total cost, and the delivery address of the customer if necessary. After baking, the chef sends the order to the order box. If the client does not need the order to be delivered, the order is given to the customer. If delivery is ordered, the order is transferred to the courier. The courier delivers the pizza to the customer to the address specified in the order. After delivery, the customer pays the order.

There is the following description for the DEMO methodology (Figures 6-9).

These diagrams describe the organization as a system and give a complete picture of its activity, but omit the description of the technological content of the activi-

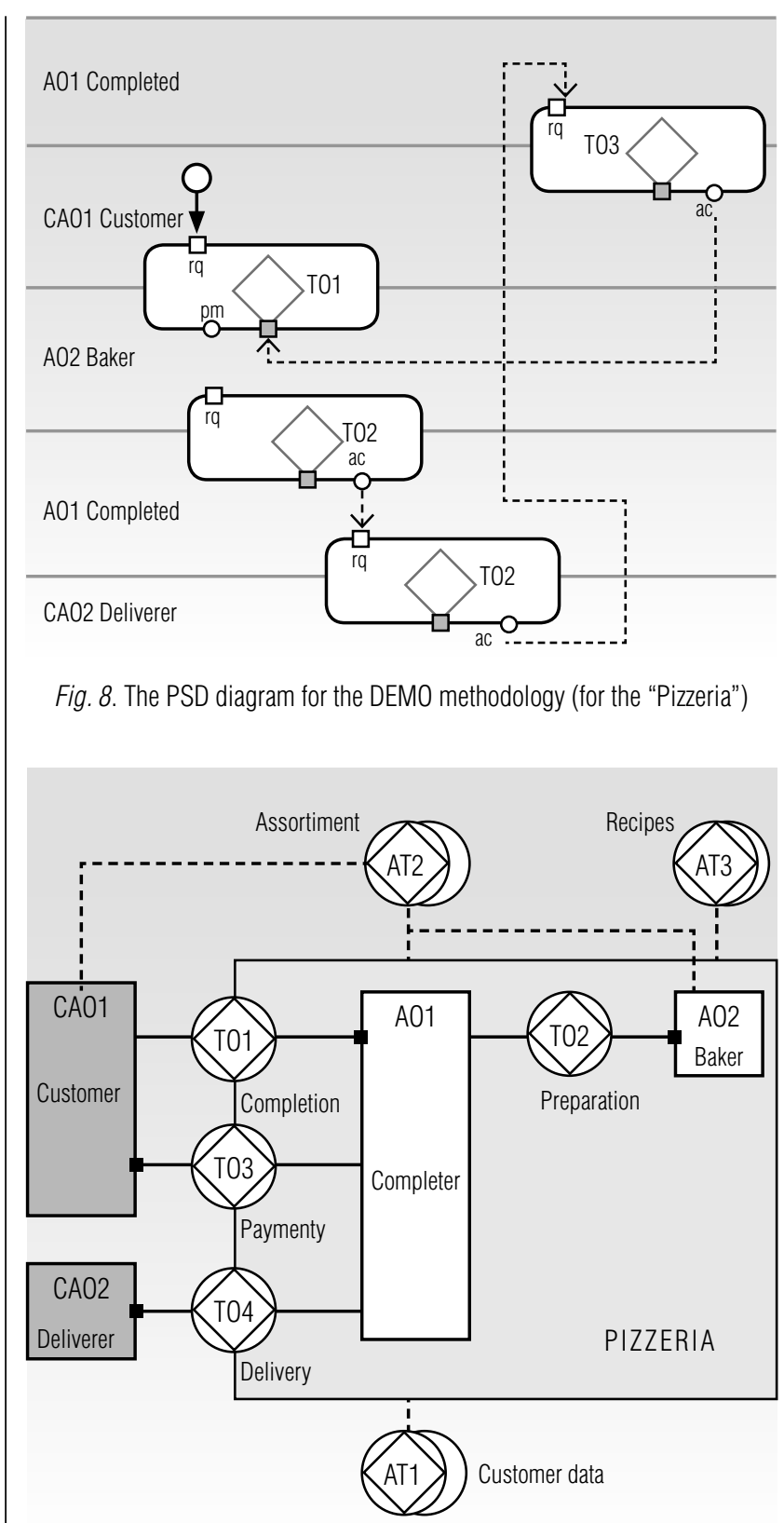

Fig. 9. The OCD diagram for the DEMO methodology (for the "Pizzeria")

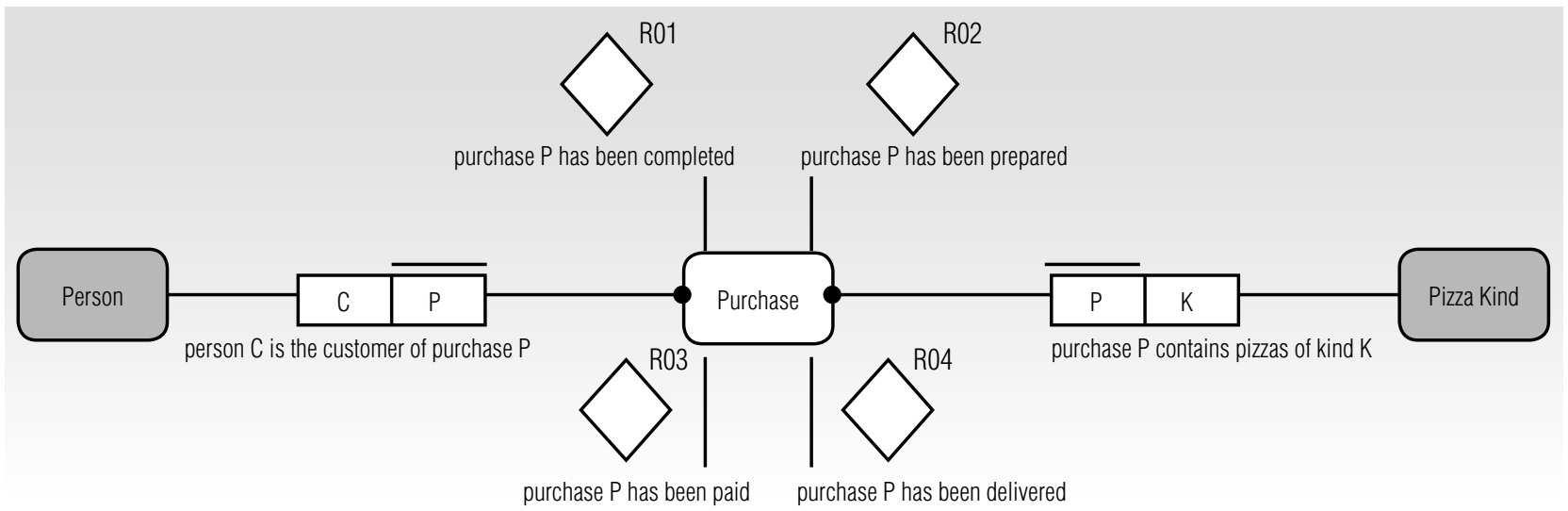

Fig. 7. The OFD diagram for the DEMO methodology (for the "Pizzeria") 
ties, because the DEMO methodology describes the ontological level of the organization.

Let's consider the "Pizzeria" example using BORM (Figures 10-12) methodology. This methodology involves the description of not only the ontological level of organization, but also datalogical and infological. That is why the business processes are considered with the demonstration of all involved technologies and data-

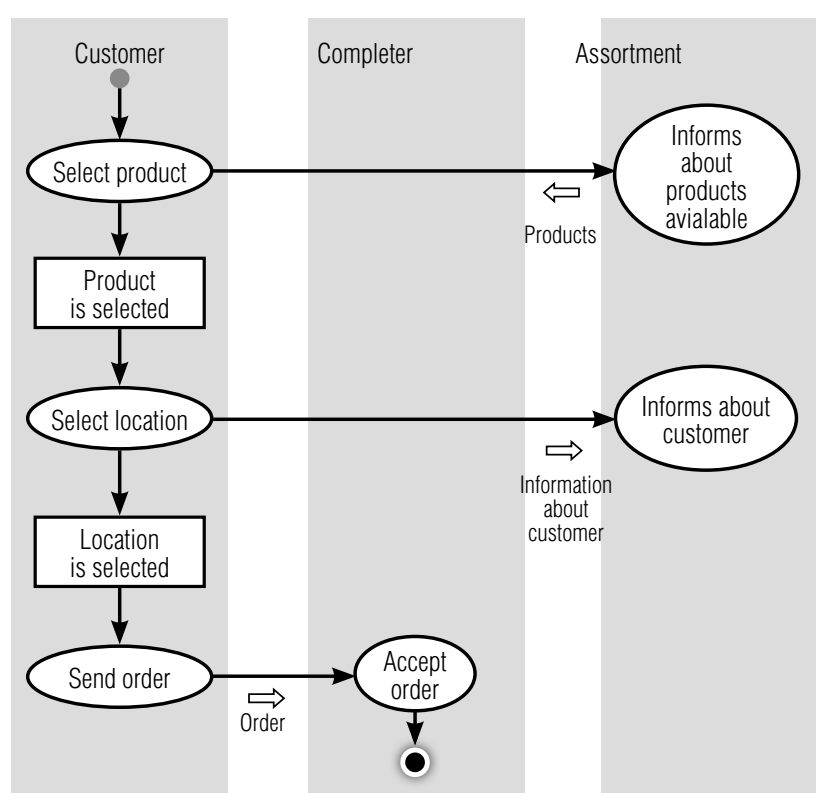

Fig. 10. The description of the ordering process with the BORM methodology (for the "Pizzeria")

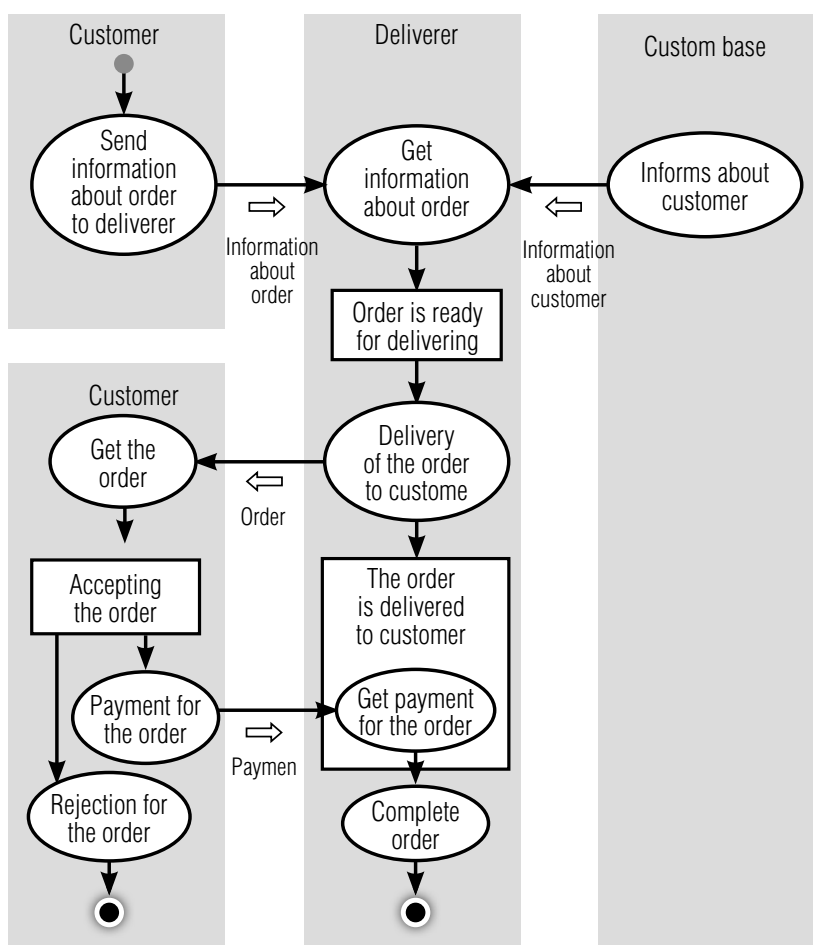

Fig. 11. The description of the process of order preparation with the BORM methodology (for the "Pizzeria")

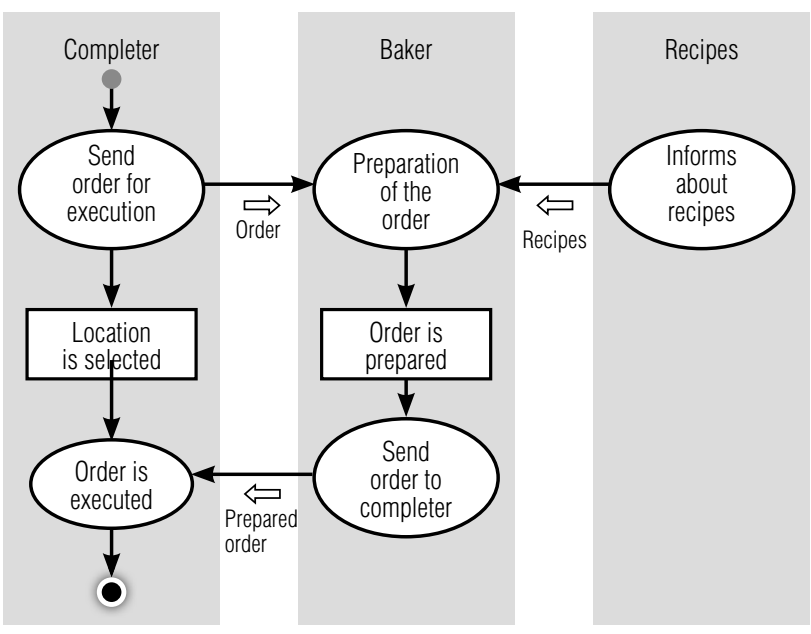

Fig. 12. The description of the process of order delivery with the BORM methodology (for the "Pizzeria")

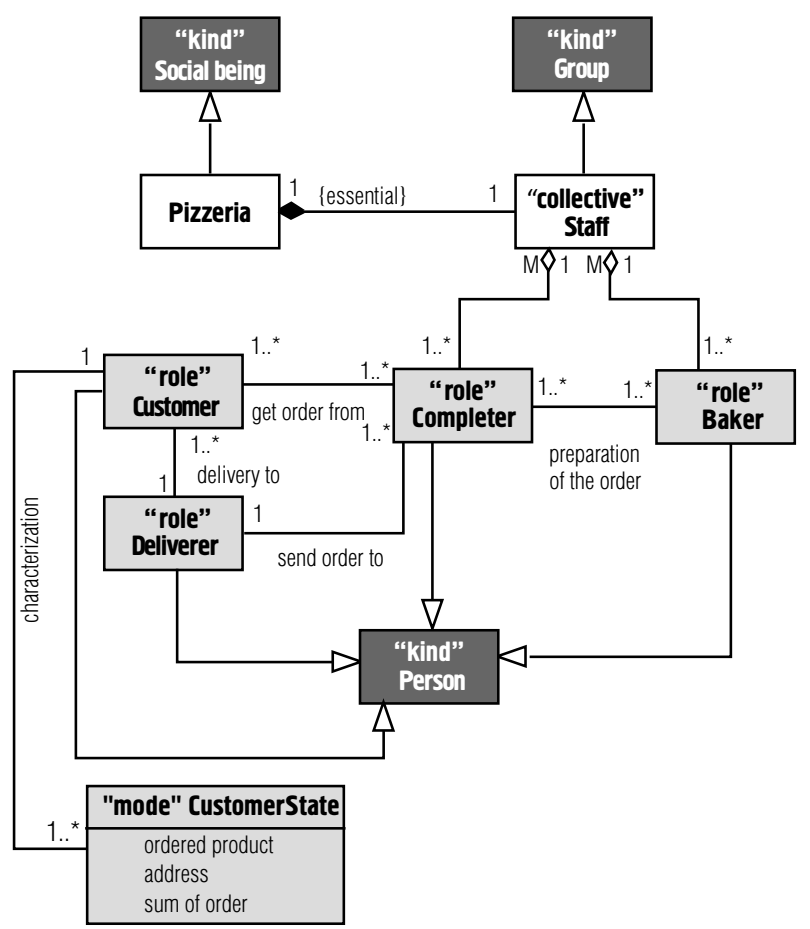

Fig. 13. Description of "Pizzeria" within OntoUML (UF0-A) methodology

bases, so the description with the BORM methodology takes a few diagrams.

Furthermore, it is essential to give a description of this case using the OntoUML methodology. Because the presently existing version UFO-A describes only objects, their interaction and hierarchy, it is difficult to assess it with the DEMO or BORM methodologies, which focus on the description of the organization's business processes (Figure 13). But OntoUML, as well as the DEMO methodology, considers the ontological level of the organization and describes its objects. 
In order to evaluate the effectiveness of the existing methodologies, we conducted a survey in which we asked a group of business analysts to choose the methodologies that are more suitable in the specified business situation:

1. The company "Pizzeria" has lost $30 \%$ of its revenue today because a few orders were delivered to the wrong address, despite the fact that information obtained by a person with the role of "Completer" was correct. What was the reason?

2. The company "Pizzeria" decided to create a website so customers could place an order online. What changes are needed in the current process?

3. The company "Pizzeria" has decided to open another branch in the city center, which is going to operate in the same way as the existing one. But it needs to reorganize the staff and hire full-time couriers. How will this affect the current process of work?

4. It became clear that it is unprofitable for the organization to keep two full-time cooks, because their workload is $50 \%$. Therefore, to reduce costs, it has decided to keep the process of orders preparation within one market place. The other branches just deliver ready semi-finished products. What influences the decision?

Analysis of expert responses shows that it is appropriate to use the BORM methodology in case the changes do not affect the course of the process as a whole, because only this methodology shows the details of the process and allows us to understand which stages of the proc- ess have failed. When it comes to changing the working process in general, which affects the processes at the ontological level, the DEMO methodology is more suitable. When we are talking about fundamental changes in the process of work, affecting the employee hierarchy, it is advisable to use the OntoUML methodology along with the DEMO methodology, because they describe the relationships and staff communication within the company (Table 5).

From the examples and the results provided, we may conclude that the methodologies considered have a lot of similarities and differences, but they focus on the different aspects and activities of the organization using different methods of analysis. That is why for the multifaceted analysis of organization it is essential to take into account the results of simulation analysis using the methodologies investigated combining their results.

\section{Conclusion}

As noted above, the DEMO, BORM and OntoUML methodologies use different ways for analysis of the organization and its business processes. In order to completely realize the process of organization modeling, it has been essential to combine these three methodologies, comparing them and identifying common elements and concepts.

Firstly, it has been useful to describe in detail each of the specified methodologies, reveal the essence of their

Table 5.

The responses of experts to the questions above

\begin{tabular}{|c|c|c|c|c|}
\hline Experts & $\begin{array}{l}\text { Answers to } \\
\text { Question } 1\end{array}$ & $\begin{array}{l}\text { Answers to } \\
\text { Question } 2\end{array}$ & $\begin{array}{l}\text { Answers to } \\
\text { Question } 3\end{array}$ & $\begin{array}{l}\text { Answers to } \\
\text { Question } 4\end{array}$ \\
\hline Expert 1 & $\begin{array}{l}\text { BORM, as it will } \\
\text { require evaluation at the } \\
\text { infological or datalogical } \\
\text { level in order to get a full } \\
\text { picture of the situation }\end{array}$ & $\begin{array}{l}\text { DEMO, because there will be } \\
\text { changes of the process at the onto- } \\
\text { logical level, and BORM, because } \\
\text { it will be necessary to show pecu- } \\
\text { liar features at the infological level } \\
\text { due to the new information flows }\end{array}$ & $\begin{array}{l}\text { OntoUML - because there will be } \\
\text { changes in relationships. }\end{array}$ & $\begin{array}{l}\text { OntoUML - because there will } \\
\text { be changes in relationships, and } \\
\text { DEMO, because the process of } \\
\text { work will be changed radically. }\end{array}$ \\
\hline Expert 2 & BORM & DEMO & DEMO & OntoUML \\
\hline Expert 3 & BORM & BORM, DEMO & DEM0, OntoUML & OntoUML \\
\hline Expert 4 & BORM & $\begin{array}{l}\text { DEMO, the changes in business } \\
\text { model will lead to the changes in } \\
\text { the process at the highest level }\end{array}$ & $\begin{array}{c}\text { OntoUML, } \\
\text { It needs a new hierarchy, } \\
\text { DEM0, If we hire full-time couri- } \\
\text { ers, it will change the model of } \\
\text { processes at the ontological level. }\end{array}$ & $\begin{array}{l}\text { OntoUML, } \\
\text { DEMO }\end{array}$ \\
\hline Expert 5 & $\begin{array}{l}\text { BORM, because it is } \\
\text { probably a failure in the } \\
\text { information flow }\end{array}$ & BORM & DEMO & $\begin{array}{l}\text { DEMO, this will require a change } \\
\text { in the business-processes of the } \\
\text { company due to the change of its } \\
\text { business model }\end{array}$ \\
\hline Expert 6 & BORM & DEMO & DEMO & OntoUML, DEMO \\
\hline Expert 7 & BORM & DEMO & OntoUML & DEMO \\
\hline
\end{tabular}


diagrams, notations and basic principles. The results have demonstrated that the unified methodology could better serve the purpose of multifaceted modeling of organizational structure.

Secondly, in order to solve the problem of the missing tool support for these methodologies, it has been worthwhile to represent this unified methodology in the form of the meta-model, which has been used as a basis for a future open software platform for multifaceted organization modeling.

Using the Eclipse EMF technology for developing this meta-model, the future software will be provided with extensibility and the opportunity for integration with other Eclipse projects. This meta-model may be presented as a basis for international consulting companies.

Furthermore, in the framework of this research it has been desirable to assess the completeness, validity and scope of the DEMO, BORM and OntoUML method- ologies for describing enterprise architecture within the Zachman framework. It was found that the set of the investigated methodologies has allowed a detailed description of business processes of the organization at different levels, from the ontological to the datalogical. At the same time, none of them has involved the description of software implementation, the time component and goal setting. Therefore, it is advisable in the future to consider the possibility of combining the DEMO, BORM and OntoUML methodologies with other tools to overcome the drawback.

The analysis presented above of the investigated methodologies based on the opinions of experts has also shown that only the combined use of the DEMO, BORM and OntoUML methodologies allows us to describe the organization completely. The new methodology is going to make it possible to assess the quality and reflect the whole picture, which is important for the process of multifaceted organization modeling.

\section{References}

1. Barjis J. (2007) Developing executable models of business systems. Proceedings of the Ninth International Conference on Enterprise Information Systems (ICEIS 2007). Funchal, Madeira, Portugal, 12-16 June 2007, pp. 5-13.

2. Dietz J. (1999) Understanding and modeling business processes with DEMO. Proceedings of the 18th International Conference on Conceptual Modeling. Paris, France, 15-18 November 1999, pp. 188-202.

3. Knott R.P., Merunka V., Polak J. (2009) BORM - Business Object Relation Modeling. Paper presented at 15th Americas Conference on Information Systems (AMCIS 2009), San Francisco, California, USA, 6-9 August 2009.

4. Guizzardi G. (2005) Ontological foundations for structural conceptual models. Twente, the Netherlands: Centre for Telematics and Information Technology, University of Twente.

5. Gronback R.C. (2009) Eclipse modeling project: A Domain-Specific Language (DSL) Toolkit. Addison-Wesley Professional.

6. Zachman J.A. (2003) Excerpted from the Zachman framework: A primer for enterprise engineering and manufacturing. $O M G B R W G$ ' RFI (electronic journal), no. 15. Available at: http://www.businessrulesgroup.org/BRWG_RFI/ZachmanBookRFIextract.pdf (accessed 05 February 2016).

7. Dietz J. (2006) Enterprise ontology: Theory and methodology. Berlin, Heidelberd: Springer-Verlag.

8. Huysmans Ph., Ven Kr., Verelst J. (2010) Using the DEMO methodology for modeling open source software development processes. Information and Software Technology, no. 16, pp. 656-671.

9. Merunka V. (2010) Object-oriented process modeling and simulation - BORM experience. Trakia Journal of Sciences, vol. 8, no. 3, pp. 71-87.

10. Podlouck'y M., Pergl R. (2014) Towards formal foundations for BORM ORD validation and simulation. Paper presented at the 16th International Conference on Enterprise Information Systems (ICEIS). Lisbon, Portugal, 27-30 April 2014.

11. Guizzardi G., Graças A.P., Guizzardi R.S.S. (2011) Design patterns and inductive modeling rules to support the construction of ontologically well-founded conceptual models in OntoUML. Proceedings of the 3rd International Workshop on Ontology-Driven Information Systems (ODISE 2011), together with the 23rd International Conference on Advanced Information System Engineering (CAiSE'11). London, UK, 20-24 June 2011, pp. 402-413.

12. Barjis J. (2011) Enterprise modeling and simulation within enterprise engineering. Journal of Enterprise Transformation, no. 22 , pp. $185-207$.

13. Levenchuk A. (2014) Sistemno-inzhenernoe myshlenie v upravlenii zhiznennym ciklom [Systematic engineering thinking in the lifecycle management]. Moscow: TechInvestLab (in Russian).

14. Guizzardi G., Salles T.P. (2014) Detection, simulation and elimination of semantic antipatterns in ontology-driven conceptual models. Proceedings of the 33rd International Conference on Conceptual Modeling (ER 2014). Atlanta, USA, 27-29 October 2014, pp. 363-376.

15. Object Management Group (2015) Business Motivation Model (BMM). Version 1.3. Available at: http://www.omg.org/spec/BMM/1.3/ (accessed 25 April 2016) 


\section{Применение технологии Eclipse EMF для многоаспектного моделирования организации}

\section{Э.А. Бабкин}

кандидат технических наук, PhD in Computer Science профессор кафедры информационных систем и технологий

Национальный исследовательский университет «Высшая школа экономики»

Адрес: 603155, г. Нижний Новгород, ул. Большая Печерская, д. 25/20

E-mail:eababkin@hse.ru

\section{О.В. Радзинская}

преподаватель кафедры информационных систем и технологий

Национальный исследовательский университет «Высшая школа экономики»

Адрес: 603155, г. Нижний Новгород, ул. Большая Печерская, д. 25/20

E-mail: oradzinskaya@hse.ru

\section{Аннотация}

В данной работе исследуются наиболее развитые методологии, используемые для многоаспектного моделирования организации. Проблематика заключается в различных подходах исследуемых методологий (DEMO - Design and Engineering Methodology for Organizations, BORM - Business Object Relation Modeling и OntoUML) к анализу организации и ее бизнес-процессов, что приводит к различным результатам, усложняющим процесс организационного моделирования. Кроме того, на данный момент нет программного обеспечения, позволяющего работать с данными методологиями. Именно поэтому целью данной работы является создание с помощью технологии EclipseEMF единой мета-модели, базирующейся на исследуемых, и анализ полноты модели для описания архитектуры предприятия. Созданная мета-модель будет служить основой для новой открытой платформы для многоаспектного моделирования.

В ходе изучения и анализа данных методологий было выявлено, что их совокупность содержит все концепты, присущие системному подходу к моделированию организации, а также позволяет провести детальный анализ бизнес-процессов организации, объектов и их взаимосвязей. Поэтому совокупность методологий предоставляет исчерпывающую информацию для многоаспектного моделирования бизнеспроцессов организации. Именно поэтому данные методологии необходимо рассматривать вместе.

Для оценки возможности объединения данных методологий было проведено их детальное сравнение. Результаты показали, что, несмотря на то, что данные методологии анализируют разные сферы деятельности организации, у них есть общий базовый набор концептов, принципов и элементов. На базе выделенных групп общих элементов и с помощью технологии Eclipse EMF была создана обобщенная мета-модель в форме Ecore-модели, являющаяся основой полноценной среды моделирования. Эта модель не только включает инструментарий для DEMO, BORM и OntoUML, но и содержит их связи, что предоставляет пользователю возможность для проведения многоаспектного анализа организации и способствует выработке нового подхода к моделированию организации. С помощью модели Захмана было выявлено, что эти методологии позволяют провести описание бизнес-процессов на разных уровнях организации, от онтологического до даталогического, представляя исчерпывающую информацию для многоаспектного моделирования. Однако все исследуемые методологии упускают из внимания временной аспект и целеполагание.

Ключевые слова: многоаспектное моделирование организации, архитектура предприятия, DEMO, BORM, OntoUML, унифицированная методология, модель Захмана, Eclipse EMF, систематическое моделирование организации.

Цитирование: Babkin E.A., Radzinskaya O.V. Application of the Eclipse EMF technology for multifaceted organization modelling // Business Informatics. 2016. No. 3 (37). P. 15-29. DOI: 10.17323/1998-0663.2016.3.15.29.

\section{Литература}

1. Barjis J. Developing executable models of business systems // Proceedings of the Ninth International Conference on Enterprise Information Systems (ICEIS 2007). Funchal, Madeira, Portugal, 12-16 June 2007. P. 5-13.

2. Dietz J. Understanding and modeling business processes with DEMO // Proceedings of the 18th International Conference on Conceptual Modeling. Paris, France, 15-18 November 1999. P. 188-202. 
3. Knott R.P., Merunka V., Polak J. BORM - Business Object Relation Modeling // 15th Americas Conference on Information Systems (AMCIS 2009), San Francisco, California, USA, 6-9 August 2009.

4. Guizzardi G. Ontological foundations for structural conceptual models. Twente, the Netherlands: Centre for Telematics and Information Technology, University of Twente, 2005. 441 p.

5. Gronback R.C. Eclipse modeling project: A Domain-Specific Language (DSL). Toolkit. Addison-Wesley Professional, 2009. 736 p.

6. Zachman J.A. Excerpted from the Zachman framework: A primer for enterprise engineering and manufacturing // OMG BRWG's RFI, 2003. [Электронный ресурc]: http://www.businessrulesgroup.org/BRWG_RFI/ZachmanBookRFIextract.pdf (дата обращения 05.02.2016).

7. Dietz J. Enterprise ontology: Theory and methodology. Berlin, Heidelberd: Springer-Verlag. 2006. 240 p.

8. Huysmans Ph., Ven Kr., Verelst J. Using the DEMO methodology for modeling open source software development processes // Information and Software Technology. 2010. No. 16. P. 656-671.

9. Merunka V. Object-oriented process modeling and simulation - BORM experience // Trakia Journal of Sciences. 2010. Vol. 8, no. 3. P. 71-87.

10. Podlouck'y M., Pergl R. Towards formal foundations for BORM ORD validation and simulation // 16th International Conference on Enterprise Information Systems (ICEIS). Lisbon, Portugal, 27-30 April 2014.

11. Guizzardi G., Graças A.P., Guizzardi R.S.S. Design patterns and inductive modeling rules to support the construction of ontologically well-founded conceptual models in OntoUML // Proceedings of the 3rd International Workshop on Ontology-Driven Information Systems (ODISE 2011), together with the 23rd International Conference on Advanced Information System Engineering (CAiSE'11). London, UK, 20-24 June 2011. P. 402-413.

12. Barjis J. (2011) Enterprise modeling and simulation within enterprise engineering // Journal of Enterprise Transformation. 2011. No. 22. P. $185-207$.

13. Левенчук А. Системно инженерное мышление в управлении жизненным циклом. M.: TechInvestLab, 2014. 306 c.

14. Guizzardi G., Salles T.P. Detection, simulation and elimination of semantic antipatterns in ontology-driven conceptual models // Proceedings of the 33rd International Conference on Conceptual Modeling (ER 2014). Atlanta, USA, 27-29 October 2014. P. 363-376.

15. Business Motivation Model (BMM). Tutorial // Object Management Group, 2015. [Электронный pecypc]: http://www.omg.org/spec/ ВMМ/1.3/ (дата обращения 25.04.2016). 


\title{
Modelling the financial stability of an enterprise taking into account macroeconomic indicators
}

\author{
Davit S. Bidzhoyan \\ Postgraduate Student, Department of Business Analytics, Doctoral School of Economics \\ National Research University Higher School of Economics \\ Address: 20, Myasnitskaya Street, Moscow, 101000, Russian Federation \\ E-mail: bidzhoyan_david@mail.ru
}

\section{Tatiana K. Bogdanova}

Associate Professor, Department of Business Analytics

National Research University Higher School of Economics

Address: 20, Myasnitskaya Street, Moscow, 101000, Russian Federation

E-mail: tanbog@hse.ru

\begin{abstract}
Nowadays enterprises operate in a rapidly changing macroeconomic environment, and this factor should be taken into account when forecasting a company's financial statement as a whole, or some of its particular aspects. However, development of the company's financial stability assessment model taking into account macroeconomic factors is hampered by the problem of inclusion in the model of some factors with frequency of measurement different from that of the internal financial performance. For example, currency rates and crude oil prices can change on a daily, weekly, or monthly basis. Changes in the key interest rate cannot be characterized as systematic, since the Central Bank can vary the key interest rate depending on market conditions. Meanwhile, financial indicators of the company are published in the semi-annual and annual reports.

This paper proposes an approach that aggregates macroeconomic factors, which means presenting a time series of each variable for each year, followed by the inclusion of polynomial coefficients in the final model as reference variable characteristics. The weighted average is calculated for the key interest rate, where the weights are the days during which the rate is operated. Based on the data of 291 metallurgical industry enterprises of the Volga federal district for the period 2012-2014, a financial stability assessment model has been built relying on the decision tree model using CRT (Classification and Regression Tree). The accuracy of the model is approximately $86 \%$. The decision tree structure has served as a basis for recommendations to optimize certain financial indicators of operations to reach financial stability.
\end{abstract}

Key words: financial stability, aggregation of macro-economic factors, polynomial function, decision tree, inventories, net assets, fixed assets, key interest rate, consumer price index.

Citation: Bidzhoyan D.S., Bogdanova T.K. (2016) Modelling the financial stability of an enterprise taking into account macroeconomic indicators. Business Informatics, no. 3 (37), pp. 30-37. DOI: 10.17323/1998-0663.2016.3.30.37.

\section{Introduction}

I nstitutions of stock and currency markets, global trade in goods produced by manufacturers from different countries and the oil trade determine the macroeconomic environment in which a company operates. This is not a complete list of parameters that characterize the macroeconomic situation. They may also include the consumer price index, unemployment and interest rates on loans and deposits, that are largely determined by the size of the key interest rate, and other indicators. For example, changes in exchange rates have a direct impact on enterprises conducting international activities, and indi- 
rectly affect enterprises with a domestic market orientation through structural changes in the economy. However, the abovementioned parameters' nature and degree of influence on the financial state of a company are uncertain. Moreover, the impact of changes in these parameters may have different effects on enterprises' performance depending on the nature of their interaction with the environment. For example, whether they carry out procurement of raw materials in foreign currencies, where are the primary market channels, etc. The financial condition of a company heavily depends on its ability to quickly adapt to the macroeconomic conditions.

Thus, the relevance of this study is based on the necessity to consider the macroeconomic factors when forecasting an enterprise's financial condition.

\section{Review of existing methods of forecasting an enterprise's financial state}

In the course of the last 80 years different methods and models of forecasting the financial condition of a company have been developed and applied.

The first attempts of such modelling were made in the 1960s. W. Beaver [1] proposed an expert assessment model of financial instability depending on financial flows. The conclusion was based on the analysis of trends in business performance of 79 industries turned bankrupt during the period from 1954 to 1964. Six indicators were selected:

$\downarrow$ the ratio of cash flow to the total debt;

$\checkmark$ the ratio of net profit to total assets;

$\checkmark$ the ratio of total liabilities to total assets;

$\checkmark$ the ratio of working capital to total assets;

$\downarrow$ liquidity ratio;

$\checkmark$ current assets minus current liabilities.

As a result, the analysis revealed a trend toward performance degradation of bankrupt enterprises, and the uptrend of financially healthy companies. The disadvantage of this approach is the difficulty of interpreting the results in the condition of divergent changes in the coefficients.

E. Altman's Z-score model (1968) [2] of multiple discriminant analysis (MDA) overcame the drawbacks of the W. Beaver's model. The MDA model is a derivation of an integral index on which the conclusion for the analyzed aspect of the financial condition is based. The model is as follows:

$$
Z=a_{1} X_{1}+a_{2} X_{2}+\ldots+a_{i} X_{i}
$$

where $Z$ - scoring value;

$a_{i}$ - coefficients of the variables;

$X_{i}$ - the factors determining the value of scoring.
In essence, this model is a model of regression analysis of a finite number of determining factors. The best known models are those of two-, five- and seven-factor models. Based on an MDA, a huge number of models was developed, both foreign and domestic. E. Deakin [3] puts forward a requirement on allocation normality of model factors values that is very difficult to achieve in practice. The idea of using a dynamic model of MDA, with the inclusion of lagged variables belongs to R. Edmister [4]. The use of standard deviations made it possible to increase the predictive accuracy of the model. M. Blum [5] applied the MDA to assess the probability of bankruptcy by maximizing the difference between bankrupt enterprises and financially healthy businesses, while minimizing the differences within each group.

The most popular method among modern scientists when analyzing solvency and bankruptcy of an enterprise is the logistic regression model constructed by D. Chesser [6]. One of the advantages of logistic regression is obtaining the probability of the analyzed event. In addition, there are various tools that can be used to obtain additional information on the model factors. This greatly facilitates the decision-making process. Those tools are ROC-curves, imaging quality of predictive models; marginal effects, showing the change in the probability of an event when each predictor changes by 1 , and others. These features greatly facilitate the decision making process. Among foreign studies on this issue, J. Olson's study is the best known [7]. Among Russian scholars, we should mention publications of T. Bogdanova and Yu. Alekseeva [8]. In the case of nonlinear relationships between the dependent variable and the independent factors, the most preferred method is the use of neural networks, because neural networks are universal approximations, allowing us to identify any hidden dependencies between variables. The advantage of neural networks is the absence of data requirements (normal distribution, "the curse of dimensionality", multicollinearity, etc.). The Neural Network toolbox is so wide/extensive that the problem of bankruptcy prediction (solvency) can be solved in different ways. One of them is a hybrid method based on the Bayesian neural network ensemble and logit model [9]. The problem also can be solved by means of classification by neural networks [10], clustering by self-organizing Kohonen maps. However, despite the versatility of this method, there are some drawbacks related with selecting the type of model from a large number of different parameters (number of hidden layers, the kind of activation function, etc.), the problem of retraining, etc. If there are linear relationships between variables, classic regression models show a better result compared with neural networks [11]. 


\section{Testing the classic models in a period of crisis}

The afore-mentioned and comparable models were designed and tested in a relatively stable macroeconomic situation: the absence of large, significant fluctuations in financial and currency markets, a situation beneficial both for industries and enterprise activities. Thus, it was not necessary to include macro-economic factors in the model due to their relative permanency. This observation has been confirmed by the high predictive accuracy of models: in Altman's model, bankruptcy prediction accuracy for a year was $95 \%$, while neural networks provided a predictive accuracy of approximately $87 \%$.

We hypothesize that the prediction accuracy of the selected models in the 2014 crisis hould had to be reduced, due to unstable macroeconomic environment. In this situation, the role of management is leveled out, since it is difficult to adapt to the rapidly changing realities. Working out a strategy for development, changing the price policy and financial activities are not easy, especially for large enterprises with an advanced and large administrative apparatus.

Table 1 shows the test results of some models of multiple discriminant analysis on the data from metallurgical enterprises of the Volga Federal District in 2014.

\section{Accuracy of classical models}

\begin{tabular}{c|c}
\hline Model & Model acouracy \\
\hline 2-factor Altman model & $33.20 \%$ \\
\hline 5-factor Altman model & $16.50 \%$ \\
\hline Taffler \& Tisshaw model & $28.08 \%$ \\
\hline Savitskaya model & $64.03 \%$ \\
\hline
\end{tabular}

The afore-mentioned models show low predictive ability. The foreign model of multiple discriminant analysis proved to be inadequate to predict the financial stability of domestic (Russian) companies. Savitskaya's model, adapted for the Russian economy, showed a higher predictive accuracy, but proved insufficient for sound decision making.

\section{Information base of the research}

771 observations from 291 enterprises of the metallurgical industry in the Volga Federal District organized as "joint-stock companies", in terms of public financial statements (forms 1 and 2) for 2012-2014 were taken as the sample for analysis. The sample includes successfully working as well as financially unstable companies (Table 2).

Table 2.

\section{Frequency analysis}

\begin{tabular}{c|c|c|c}
\hline & Frequency & Percent & $\begin{array}{c}\text { Cumulative } \\
\text { Percent }\end{array}$ \\
\hline Financially unstable firms & 440 & 57.1 & 57.1 \\
\hline Financially stable firms & 331 & 42.9 & 100,0 \\
\hline Total & $\mathbf{7 7 1}$ & $\mathbf{1 0 0 . 0}$ & \\
\hline \multicolumn{2}{|l}{}
\end{tabular}

As shown in Table 2, 440 of 771 observed firms are recognized as financially unstable, that is $57.1 \%$, and 331 are financially stable (42.9\%). Panel data were given in a cross-table view, and the model was based on that data. Table 3 shows the descriptive statistics of the financial statements setting out the financial conditions of enterprises in the whole sampling.

Table 3.

\section{Descriptive statistics of internal financial indicators}

\begin{tabular}{l|l|l}
\multicolumn{1}{c|}{ Variables } & \multicolumn{1}{c|}{ Mean } & \multicolumn{1}{c}{\begin{tabular}{c}
\multicolumn{1}{c}{ Standard } \\
deviation
\end{tabular}} \\
\hline Equity ratio & 41.42 & 32.96 \\
\hline Return on assets & -0.31 & 213.58 \\
\hline Total return & -7.58 & 553.65 \\
\hline Net assets & 103524.83 & 330749.97 \\
\hline Earnings before taxes & 22978.45 & 137118.09 \\
\hline Fixed assets & 81078.99 & 238980.45 \\
\hline Capital \& reserves & 103507.95 & 330733.91 \\
\hline Return on equity & 84859.89 & 265432.55 \\
\hline
\end{tabular}

Table 4 presents external factors characterizing the macroeconomic situation, namely the key interest rate, consumer price index, as well as the polynomial coefficients of the 4th degree listed on the stock exchange.

All the financial indicators are annual. However, exchange rates and the price of Brent change daily, hence to bring the daily values to the annual quantities in the calculations it is proposed to apply an approximation in the form of polynomials of degree $n$. To do this, it is necessary:

1. To determine a polynomial function for each year and for each variable.

2. To incorporate the coefficients in the polynomial function as separate modeling variables: 
Table 4.

Descriptive statistics of macroeconomic factors

\begin{tabular}{|c|c|c|c|}
\hline Variable & Mean & Standard deviation & Designations \\
\hline Key interest rate & 0.075 & 0.004 & rate \\
\hline Consumer price index & 1.082 & 0.023 & сpi \\
\hline Dollar currency polynomial constant & 31.817 & 1.194 & cusd \\
\hline Dollar currency polynomial trend & -0.009 & 0.124 & tusd \\
\hline Dollar currency polynomial square trend & 0 & 0 & t2usd \\
\hline Brent crude oil polynomial constant & 106.35 & 0.80 & cbrent \\
\hline Brent crude oil polynomial trend & 0.40 & 0.30 & tbrent \\
\hline Brent crude oil polynomial square trend & 0.00 & 0.01 & t2brent \\
\hline Euro currency polynomial constant & 41.22 & 1.29 & ceuro \\
\hline Euro currency polynomial trend & 0.15 & 0.22 & teuro \\
\hline Euro currency polynomial square trend & -0.01 & 0.01 & t2euro \\
\hline
\end{tabular}

$$
\begin{aligned}
& f_{i}\left(x_{t}\right)=\alpha_{0}^{i}+\alpha_{1}^{i} t+\alpha_{2}^{i} t^{2}+\ldots+\alpha_{j}^{i} t^{j}+\ldots+\alpha_{n}^{i} t^{n}+\varepsilon^{i} \\
& f_{i}\left(z_{t}\right)=\alpha_{0}^{i}+\alpha_{1}^{i} t+\alpha_{2}^{i} t^{2}+\ldots+\alpha_{j}^{i} t^{j}+\ldots+\alpha_{n}^{i} t^{n}+\varepsilon^{i} \\
& f_{i}\left(o_{t}\right)=\alpha_{0}^{i}+\alpha_{1}^{i} t+\alpha_{2}^{i} t^{2}+\ldots+\alpha_{j}^{i} t^{j}+\ldots+\alpha_{n}^{i} t^{n}+\varepsilon^{i}
\end{aligned}
$$

where $t$ - the time factor, $t=\overline{1, T}$;

$x_{t}-$ the dollar-ruble exchange rate at time $t$;

$z_{t}$ - Euro exchange rate against the ruble at time $t$;

$o_{t}$ - the cost of Brent crude oil (dollars per barrel) at time $t$; $f_{i}\left(x_{t}\right), f_{i}\left(z_{t}\right), f_{i}\left(o_{t}\right)$ - changes in macroeconomic models based on polynomial approximation to the $i$-th year;

$i$ - year of assessment of changes in macroeconomic factors, $i=\overline{1, I}$;

$\alpha_{0}^{i}$ - free term of a polynomial function in the $i$-th year;

$\alpha_{j}^{i}$ - coefficients of the $j$-th polynomial in the $i$-th year, $j=\overline{1, n}$;

$n$ - degree of the polynomial;

$\varepsilon^{i}$ - residuals error in the $i$-th year.

The polynomial coefficients of the variables are presented in Table 5.

To provide the key interest rate in an annual value, we propose to use weighted average values. The days during which the rate operates serve as a weight:

$$
r_{j}^{i}=\sum_{k=1}^{K} \frac{r_{k}^{i} \cdot n_{k}^{i}}{365}
$$

where $r_{j}^{i}$ - the weighted average of the key interest rate or tax rate of the $j$-th species in the $i$-th year;

$j-$ key interest rate or tax rate; $r_{k}^{i}-$ current key interest rate or tax rate varying $k$ times in the $i$-th year;

$n_{k}^{i}$ - number of days in the $k$-th period, during which key interest rate or tax rate remained constant in the $i$-th year;

$k$ - number of periods during which the key interest rate or tax rate were changing in the $i$-th year, $k=\overline{1, K}$.

Table 5.

Polynomial coefficients

of macroeconomic factors

\begin{tabular}{l|l|l|l}
\hline \multicolumn{1}{c|}{ Variable } & \multicolumn{1}{c|}{ Gonstant } & \multicolumn{1}{c}{ t } & \multicolumn{1}{c}{ t2 } \\
\hline usdrub_2012 & 32.44 & -0.18000 & 0.00325 \\
\hline usdrub_2013 & 30.24 & 0.00000 & 0.00000 \\
\hline usdrub_2014 & 32.92 & 0.13000 & -0.00180 \\
\hline brent_2012 & 105.43 & 0.70200 & -0.00979 \\
\hline brent_2013 & 107.35 & 0.54000 & -0.01000 \\
\hline brent_2014 & 106.098 & 0.00000 & 0.00630 \\
\hline eurorub_2012 & 40.8964 & -0.09983 & 0.00159 \\
\hline eurorub_2013 & 39.87 & 0.08700 & -0.00425 \\
\hline eurorub_2014 & 42.9 & 0.44000 & -0.01200 \\
\hline
\end{tabular}

The weighted average key interest rate for the period from 2012 to 2014 for each day is shown in the Table 6. The consumer price index from 2012 to 2014 is presented in Table 7. 
Table 6.

Weighted average values of key interest rate

\begin{tabular}{c|c}
\hline Year & Value \\
\hline 2012 & 0.0807 \\
\hline 2013 & 0.0744 \\
\hline 2014 & 0.0719 \\
\hline
\end{tabular}

\section{The proposed model}

To solve the problem of predicting the probability of financial instability in times of crisis with large fluctuations in financial and currency markets, in an unstable economy, it is necessary to take into account changes in the macroeconomic situation, such as changes in the currency exchange rates, the price of Brent oil crude, the size of the key interest rate and tax rates.

The decision tree method has been chosen to assess the financial stability of enterprise, since this method is relatively simply constructed and interpreted. There are many variants of the decision tree method. However, the CRT method (classification and regression tree) was best suited for the given sample. Since the dependent variable is a binary, as a result of its partition two subclasses are revealed. These subclasses classify the dependent variable in the best way.

As a result of construction of decision tree with 5 levels, 9 terminal nodes were identified. Splitting/partition into subclasses took place in the variables "Inventories", "Net assets" and "Fixed assets".

Table 8 presents the number of observations stuck in each terminal node, as well as the cumulative percentage.

Table 8

\section{Terminal nodes}

frequency table

\begin{tabular}{c|c|c|c}
\hline $\begin{array}{c}\text { Terminal } \\
\text { node }\end{array}$ & Frequency & Percentage & $\begin{array}{c}\text { Gumulative } \\
\text { percentage }\end{array}$ \\
\hline 1 & 265 & 34.4 & 34.4 \\
\hline 3 & 113 & 14.7 & 49.0 \\
\hline 8 & 86 & 11.2 & 60.2 \\
\hline 11 & 54 & 7.0 & 67.2 \\
\hline 12 & 40 & 5.2 & 72.4 \\
\hline 13 & 99 & 12.8 & 85.2 \\
\hline 14 & 44 & 5.7 & 90.9 \\
\hline 15 & 35 & 4.5 & 95.5 \\
\hline 16 & 35 & 4.5 & 100.0 \\
\hline Total & $\mathbf{7 7 1}$ & $\mathbf{1 0 0 . 0}$ & \\
\hline
\end{tabular}

Table 7.

Weighted average values of consumer price index

\begin{tabular}{c|c}
\hline Year & Value \\
\hline 2012 & $106.59 \%$ \\
\hline 2013 & $106.48 \%$ \\
\hline 2014 & $111.33 \%$ \\
\hline
\end{tabular}

Almost $50 \%$ of all observations were in the first and third terminal units/nodes, and $34.4 \%$ of these fell in the first node.

The probability that the company will be financially unstable is $88.3 \%$ on condition that its net assets will be less than 4006 thousand Rubles (terminal node 1). However, most likely, $94.2 \%$ - the onset of financial instability is typical for companies whose net assets are less than 53524 thousand Rubles, and inventories more than 19240 Rubles (terminal node 8). If inventories are less than a predetermined level of 19240 thousand Rubles, then, provided that the net assets are less than 18797 thousand Rubles, the likelihood of financial instability is estimated at $77.5 \%$ (terminal node 11). Otherwise, the company can be characterized as financially stable with a probability of $88 \%$ (terminal node 12 ).

Companies having inventories of more than 165973 thousand Rubles, and net assets ranging from 56524 thousand Rubles up to 456493 thousand Rubles are predicted as financially unstable with a probability of $94.3 \%$ (terminal node 15).

The companies having inventories less than 165973 thousand Rubles and fixed assets not exceeding 87731 thousand Rubles are deemed to be financially stable with a probability of $100 \%$ (terminal node 13 ). If the fixed assets are more than 87731 thousand Rubles, we can claim them as financially stable with a probability of $60 \%$.

Thus, as a result of the analysis, we can conclude that in order to achieve financial stability enterprises should optimize their operating activities. It is obvious that if inventories are large and net assets are relatively small, the onset of financial instability is inevitable.

The accuracy of the modelling on the training set was $86.4 \%$, and testing set $-85.5 \%$.

The first category of errors (the financially unstable company is recognized as financially stable) on training set constitutes is 38 observations. Errors of the second category (financially unstable companies are classified as financially stable) is 37 observations. The number of the first and the second error types constitutes 16 observations on a testing set (Table 9). 


\section{Accuracy of the model}

\begin{tabular}{|c|c|c|c|c|}
\hline & \multirow{2}{*}{ Sample } & \multicolumn{2}{|c|}{ Predicted } & \multirow{2}{*}{$\begin{array}{l}\text { Percent } \\
\text { Correct }\end{array}$} \\
\hline & & 0 & 1 & \\
\hline \multirow[t]{3}{*}{ Training } & 0 & 285 & 38 & $88.2 \%$ \\
\hline & 1 & 37 & 191 & $83.8 \%$ \\
\hline & Overall percentage & $58.4 \%$ & $41.6 \%$ & $86.4 \%$ \\
\hline \multirow[t]{3}{*}{ Test } & 0 & 102 & 16 & $86.4 \%$ \\
\hline & 1 & 16 & 86 & $84.3 \%$ \\
\hline & Overall percentage & $53.6 \%$ & $46.4 \%$ & $85.5 \%$ \\
\hline
\end{tabular}

Only internal financial indicators were used in the construction of the tree solution model. Those are net assets, fixed assets and inventories. To identify the impact of macroeconomic factors, it is necessary to run a non-parametric test to determine the equality of averages for the intervals according to which the tree split.

Table 10 shows the test results on determining the equality of averages of macroeconomic factors according to the subclasses derived from the decision tree method.

Table 10 shows that the hypothesis on the averages of the variable "Brent constant" divided by the variable "Net assets" to groups are different is accepted at the $10 \%$ level. Therefore, one can argue that Brent crude oil prices have an impact on the financial stability of enterprises in the metallurgical industry. Given the high cor- relation between the price of Brent crude oil and the rates of national currency against the dollar and the euro, we can argue that there is an effect of the afore-mentioned factors on the financial stability of the enterprise.

\section{Conclusion}

Thus, the proposed approach allows us to take into account macroeconomic factors with changing frequencies different from the frequencies of changes in the financial performance of the enterprise. The approach is based on the presentation of the time series as a polynomial function to some extent. For each of three years and for each of three variables a polynomial function was built. To calculate the probability of financial instability as characteristics of selected factors in the final model, the coefficients of polynomial functions of 2 nd degree are used. The proposed approach of macroeconomic factors aggregation decomposes each factor into three variables with no significant loss of information

A model of tree solution with the CRT method and with a 5-level depth was built. As a result of splitting the variables into "Net assets", "Inventories" and "Fixed assets", a model with 9 terminal nodes was obtained. The accuracy of the model on the training set was $86.4 \%$. On the test set $-85.5 \%$.

The average value of the variable constant "Brent oil crude" of the polynomial function for financially stable and financially unstable companies on the basis of the nonparametric test on the equality of the average values has significant differences. This confirms the assump-

Nonparametric test comparing means for independent samples within each variable

\begin{tabular}{|c|c|c|c|}
\hline \multirow{2}{*}{ Null hypothesis } & \multicolumn{3}{|c|}{ p-value } \\
\hline & Fixed assets & Inventories & Net assets \\
\hline the distribution of rate is the same & 0.725 & 0.594 & 0.314 \\
\hline the distribution of $\mathbf{p p i}$ is the same & 0.98 & 0.84 & 0.648 \\
\hline the distribution of cusd is the same & 0.98 & 0.84 & 0.648 \\
\hline the distribution of tusd is the same & 0.725 & 0.594 & 0.314 \\
\hline the distribution of t2usd is the same & 0.725 & 0.594 & 0.314 \\
\hline the distribution of ceuro is the same & 0.71 & 0.39 & 0.09 \\
\hline the distribution of teuro is the same & 0.725 & 0.594 & 0.314 \\
\hline the distribution of $\mathbf{t 2 e u r o}$ is the same & 0.98 & 0.84 & 0.648 \\
\hline the distribution of cbrent is the same & 0.98 & 0.84 & 0.648 \\
\hline the distribution of tbrent is the same & 0.725 & 0.594 & 0.314 \\
\hline the distribution of $\mathbf{t} \mathbf{2} \mathbf{b r e n t}$ is the same & 0.725 & 0.594 & 0.314 \\
\hline
\end{tabular}


tion about the impact of oil on the financial condition of an enterprise.

The "Net assets" value should correspond to the value of the "Inventories". If the "Inventories" exceed a cer- tain level, there is a great probability of financial instability. Otherwise, the company is rated as financially stable. Thus, results of the model allow us to give some recommendation for CEOs concerning financial stability.

\title{
References
}

1. Beaver W.H. (1966) Financial ratios as predictors of failure. Empirical research in accounting selected studies. Supplement to Journal of Accounting Research, no. 40, pp. 71-111.

2. Altman E.I. (1968) Financial ratios. Discriminant analysis and the prediction of corporate bankruptcy. The Journal of Finance, no. 20, pp. 589-609.

3. Deakin E.I. (1972) A discriminant analysis of predictors of business failure. Journal of Accounting Research, no. 12, pp. 167-179.

4. Edmister R.O. (1972) An empirical test of financial ratio analysis for small business failure prediction. The Journal of Financial and Quantitative Analysis, no. 16, pp. 1477-1493.

5. Blum M. (1974) Failing company discriminant analysis. Journal of Accounting Research, vol. 24, no. 1, pp. 1-25.

6. Chesser D. (1974) Predicting loan noncompliance. Journal of Commercial Bank Lending, no. 13, pp. 2-15.

7. Ohlson J. (1980) Financial ratios and the probabilistic prediction of bankruptcy. Journal of Accounting Research, no. 22, pp. 109-131.

8. Bogdanova T.K., Alekseeva Yu.A. (2011) Prognozirovanie veroyantosti bankrotstva s uchetom izmeneniya finansovyh pokazateley $\mathrm{v}$ dinamike [Forecasting the probability of bankruptcy to reflect changes in financial indicators in dynamics]. Business Informatics, no. 1 (15), pp. 50-60 (in Russian).

9. Gorbankov S.A., Beloliptsev I.I. (2013) Gibridniy metod otsenki riska bankrotstva na base bayesovskogo ansamblya neyrosetei i logit-transformatsii [Hybrid method for estimating the risk of bankruptcy based on the Bayesian ensemble of neural networks and logit models]. Naukovedenie, no. 6, pp. 1-11 (in Russian).

10. Nedosekin A.O. (2003) Metodologicheskie osnovy modelirovaniya finansovoi deyatel'nosti s ispol'zovaniem nechetko-mnozhestvennyh opisaniy [Methodological basis for modeling of financial activity using fuzzy sets descriptions]. Doctoral dissertation. Saint Petersburg (in Russian).

11. Bogdanova T.K., Shevgunov T.Ya., Uvarova O.M. (2013) Primenenie neyronnykh setey dlya prognozirovaniya platezhesposobnosti predpriyatiy obrabativayushey otrasli [Application of neural networks for solvency prediction for Russian companies of manufacturing industries]. Business Informatics, no. 2 (24), pp. 40-48 (in Russian).

\section{Моделирование финансовой устойчивости предприятия с учетом макроэкономических показателей}

\section{Д.С. Биджоян}

аспирант кафедры бизнес-аналитики, аспирантская школа по экономическим наукам

Национальный исследовательский университет «Высшая школа экономики»

Адрес: 101000, г. Москва, ул. Мясницкая, д. 20

E-mail: bidzhoyan_david@mail.ru

\section{T.K. Богданова}

кандидат экономических наук, доцент кафедры бизнес-аналитики

Национальный исследовательский университет «Высшая школа экономики»

Адрес: 101000, г. Москва, ул. Мясницкая, д. 20

E-mail:tanbog@hse.ru

\begin{abstract}
Аннотация
В настоящее время предприятия функционируют в условиях быстроизменяющейся макроэкономической ситуации. Вследствие этого появляется необходимость учета макроэкономических факторов при прогнозировании как финансового состояния предприятия в целом, так и различных его аспектов. Однако при включении макроэкономических факторов в модель, прогнозирующую финансовое состояние предприятия, возникает проблема, связанная с тем, как включать факторы, которые имеют частоту измерения, отличную от частоты измерения внутренних финансовых показателей. Так, динамика изменения курсов валют и цен на нефть
\end{abstract}


может быть разной, например, ежеминутной, ежедневной, еженедельной и т.д. Изменение ключевой ставки не носит систематический характер, оно связано с реакцией Центрального Банка на изменение конъюнктуры рынка. Финансовые показатели предприятия публикуются в полугодовых и годовых отчетах.

В статье предложен подход к агрегированию макроэкономических факторов, заключающийся в представлении временного ряда каждой переменной для каждого года с последующим включением полиномиальных коэффициентов в конечную модель в качестве характеристик исходной переменной. Для ключевой ставки рассчитывается средневзвешенный показатель, где в качестве весов выступают дни, в течение которых действовала ставка. На основе данных 291 предприятия металлургической отрасли Приволжского федерального округа за период с 2012 по 2014 годы построена модель оценки финансовой устойчивости на основе метода дерева решений методом CRT (Classification and regression tree). Точность модели составляет приблизительно 86\%. Структура полученного дерева решений позволила дать рекомендации по оптимизации определенных финансовых показателей, характеризующих операционную деятельность предприятия, для достижения им финансовой устойчивости.

Ключевые слова: финансовая устойчивость, агрегирование макроэкономических факторов, полиномиальная функция, дерево решений, запасы, чистые активы, основные средства, ключевая ставка, индекс потребительских цен.

Цитирование: Bidzhoyan D.S., Bogdanova T.K. Modelling the financial stability of an enterprise taking into account macroeconomicindicators // Business Informatics. 2016. No. 3 (37). P. 30-37. DOI: 10.17323/1998-0663.2016.3.30.37.

\section{Литература}

1. Beaver W.H. Financial ratios as predictors of failure. Empirical research in accounting selected studies // Supplement to Journal of Accounting Research. 1966. No. 40. P. 71-111.

2. Altman E.I. Financial ratios. Discriminant analysis and the prediction of corporate bankruptcy // The Journal of Finance. 1968. No. 20. P. 589-609.

3. Deakin E.I. A discriminant analysis of predictors of business failure // Journal of Accounting research. 1972. No. 12. P. 167-179.

4. Edmister R.O. An empirical test of financial ratio analysis for small business failure prediction // The Journal of Financial and Quantitative Analysis. 1972. No. 16. P. 1477-1493.

5. Blum M. Failing company discriminant analysis // Journal of Accounting Research. 1974. Vol. 24, No. 1. P. 1-25.

6. Chesser D. Predicting loan noncompliance // Journal of Commercial Bank Lending. 1974. No. 13. P. 2-15.

7. Ohlson J. Financial ratios and the probabilistic prediction of bankruptcy // Journal of Accounting Research. 1980. No. 22. P. $109-131$.

8. Богданова Т.К., Алексеева Ю.А. Прогнозирование вероятности банкротства с учетом изменений финансовых показателей в динамике // Бизнес-информатика. 2011. № 1 (15). С. 50-60.

9. Горбатков С.А., Белолипцев И.И. Гибридный метод оценки риска банкротства на базе байесовского ансамбля нейронных сетей и logit-модели // Науковедение. 2013. № 6. С. 1-11.

10. Недосекин А.О. Методологические основы моделирования финансовой деятельности с использованием нечетко-множественных описаний / Дис. ... д-ра экон. наук. СПб, 2003. 280 с.

11. Богданова Т.К., Шевгунов Т.Я., Уварова О.М. Применение нейронных сетей для прогнозирования платежеспособности российский компаний обрабатывающей отрасли // Бизнес-информатика. 2013. № 2 (24). С. 40-48. 


\title{
Mobile healthcare: Perspectives in Russia
}

\author{
Sergey M. Avdoshin \\ Professor, Head of Software Engineering School \\ National Research University Higher School of Economics \\ Address: 20, Myasnitskaya Street, Moscow, 101000, Russian Federation \\ E-mail: savdoshin@hse.ru
}

\section{Elena Yu. Pesotskaya}

Associate Professor, Software Engineering School

National Research University Higher School of Economics

Address: 20, Myasnitskaya Street, Moscow, 101000, Russian Federation

E-mail:epesotskaya@hse.ru

\begin{abstract}
This paper analyses the possibility of using mobile technologies and applications in the Russian healthcare system and evaluates the opportunities for its further development. The research provides an overview of global trends in digital healthcare with some examples of the best solutions for eHealth (healthcare practice supported by electronic processes and communication). An analysis is made of the Russian medical system in order to identify the main stages of its formation, achievements and areas for improvement. The authors also conducted research into the current Russian medical healthcare system aimed at identifying gaps and concerns regarding security, reliability and service availability for on-line and mobile services and personal health records in Russia. Certain difficulties in the establishment of an up-to-date healthcare system in Russia with examples of barriers are also analyzed to get a better understanding of the prospects for mobile healthcare development. Starting from the premise that support for information technologies is essential to medical healthcare development, the paper gives an overview of the current IT initiatives of the Russian government in the field of medicine and provides examples of the independent applications of Russian software developers for digital and mobile healthcare. As a result of the research, three possible development scenarios of Russian mobile healthcare are described. The barriers identified as well as worldwide healthcare transformation aspects such as cost reduction and personalization are considered in the possible scenarios.
\end{abstract}

Key words: healthcare system, mobile healthcare, IT health monitoring, personal health records, medical information system, mobile services, information technologies.

Citation: Avdoshin S.M., Pesotskaya E.Yu. (2016) Mobile healthcare: Perspectives in Russia. Business Informatics, no. 3 (37), pp. 38-44. DOI: 10.17323/1998-0663.2016.3.38.44.

\section{Introduction}

A ccording to global trends, the world population is becoming more dependent on healthcare services due to natural aging. By 2030 over 37 million people will suffer from at least one chronic condition, 14 million will be suffering from diabetes; half will have arthritis and more than one-third or over 21 million, will be classified as obese [1]. Similar problems exist across the developed world. The number of healthcare professionals is decreasing in many countries, and this is becoming a real problem for maintaining health. In this situation, due to a shortage of traditional medical care, people tend to turn to modern IT services and technologies, searching the Internet and their smart devices for tips on how to behave in this or that situation.

Mobility in healthcare means leveraging healthcare and information technologies to provide a different kind 
of services - from using mobile networks as a means of providing information at the most basic level, to complete diagnosis and consultation at the most sophisticated stage, including patient record keeping, applications and keeping track of the individual's medical history. These days, global medicine can monitor health issues with "intelligent shirts" through electrodes, use sensors to monitor patients' vital signs, activity sensors and webcams. It is not a regular service available to everyone, but it is part of a trend that will continue to grow in the near future. A large number of applications - from handheld devices to facilitate remote diagnosis to touchscreen technologies and "smart" devices will facilitate remote monitoring and communication. It is absolutely true that healthcare is moving away from paper-based files toward electronic medical records, though in Russia still many people, mostly from the Soviet generation, do not trust their diagnoses and treatment, unless they are printed out. In addition, many doctors from public clinics think they cannot communicate properly with their patients unless they get everything down on paper.

Some medical experts consider that the primary goal of mobile healthcare (mHealth) [2] is to get information from one location to another safely and securely. Moreover, this is not possible without cloud-based applications and services. Cloud computing in healthcare has been viewed with some caution so far, due to security concerns surrounding highly sensitive patient information and, in many cases, compliance requirements.

Worldwide trends in the healthcare sector that have a bearing on mobile Health can be summarized as follows [3]:

$\checkmark$ there is an increased focus on prevention rather than cure;

\ EMR (Electronic Medical Records) are planned, but their popularity is still low;

^ "mobile" is not yet factored as a separate element of health budgets.

This shows that healthcare transformation will continue to focus on cost reduction and personalization. The customer model is becoming increasingly personalized (via biology and services), necessitating the ability to test the effectiveness of personalized treatments and services. Increased consumerism and competition will create a transparent, value-conscience market requiring readily available cost and quality information. The need for affordability will demand new technology and innovative solutions to drive down labor costs, significantly changing standard provider-person and community interactions

\section{Global trends}

Turning to information services and mobile devices is becoming a real trend for both patients and medical professionals. More than $80 \%$ of practicing physicians worldwide use mobile devices such as smartphones and tablets, along with various types of medical applications in these devices. Imagers are often adopted earlier than other innovation technologies, and radiologists have been quick to adopt mobile devices, for both personal and professional use [4]. More variety in mobile devices will soon mean that healthcare programs using mobile technology may become common. Global mobile health revenue will increase nearly six-fold to $\$ 23$ billion by 2017. Monitoring services and applications are expected to represent $65 \%$ of the market in 2017 , driven primarily by the rapidly aging population in developed countries and the high levels of chronic disease in emerging markets. PwC experts estimate that mobile-enabled monitoring services, like those offered for chronic disease management, will make up $65 \%$ of the worldwide mobile Healthcare market and account for $\$ 15$ billion of revenue by 2017. New technology is not enough. Widespread adoption of mHealth will require changes in the behavior of actors who are trying to protect their interests [5].

A survey carried out by Accenture shows that patients are embracing eHealth, but still want to have face-toface contact with doctors, though $76 \%$ of patients say the use of technology to manage their health has the potential to improve their health [6]. The use of mobile technologies within the health sector can be divided into several categories. These include: education, monitoring, staff tagging, asset tracking, tailor-made networks for hospitals and healthcare buildings, protection of healthcare workers during home visits, mobile applications, electronic medical records and mobile smartphone applications.

According to MobiHealthNews research [7], more than 15,000 consumer health apps were available in Apple's AppStore at the end of 2015. Consumer health apps focus on general health and wellness; new apps are being developed for informational purposes and not medical diagnosis. The number of people downloading fitness and healthcare applications is increasing. These include a growing band of iPhone applications developed by big pharma, such as Pfizer (with "Robitussin Relief Finder" and "Novartis Kick Smoking"), Sanofi-Aventis and a number of other companies.

New developments in labels include QR code technology, whereby manufacturers can track their prod- 
uct more effectively or consumers can download more information on the product or related products using a mobile device such as a smartphone or tablet.

EHR (Electronic Health Records system) is believed to be of great benefit to the mobile health sector of the future. However, in practice, their implementation is complex and expensive, and adoption on a global scale is low. The advantages of digital health records are that all medical records are centralized, making them available to care providers, thereby enabling quicker diagnosis and treatment. The difficulties of implementation include the fact that universally most health practices are too small to bear the costs of implementing electronic health records.

The concept behind the PHR (Personal Health Record) is that medical records are stored by a third party provider so that they can be accessible in whole or in part by healthcare professionals as and when needed. Ultimately though, mobile PHR systems represent the potential for significant changes in how medical data are stored and used. PHRs also represent a change in the "ownership" of health information - from the medical institution, or health authority, to the individual, who is thereby empowered. Eventually, the argument goes, the "cure" is replaced by continuous monitoring before any cure is needed.

The latest trend also worth mentioning in worldwide mHealth development is the active use of mHealth knowledge to integrate the traditional patient anamnesis data and the results of genetic research with further penetration of research knowledge to pediatricians and regular medical institutions. However, this new mHealth format of medical data analysis and sharing has not gotten much recognition in Russia so far.

\section{Healthcare in Russia}

\subsection{Healthcare structure overview}

The structure of the health system varies significantly from country to country. The Russian Federation has inherited its healthcare system from the Soviet Union. Under the Constitution, Russian citizens and permanent residents are entitled to free medical care. Structurally, this is carried out through a government-organized health insurance system referred to as the obligatory medical insurance scheme. The funding come from a healthcare tax imposed on all registered employers, who contribute the equivalent of just over $3 \%$ of each employee's income towards the healthcare fund. The remaining portion of the overall healthcare budget is pro- vided by the state. While the structure appears promising and compelling, the overall healthcare budget accounts for less than $4 \%$ of the country's GDP. Comparatively speaking, this is extremely low, given that an average industrial nation allocates between $8-11 \%$ of its GDP for healthcare.

Substantial effort has been made in recent years to boost the government fund allocation for the country's healthcare needs, however it will take considerable time before any significant results begin to show. The National Priority Project "Zdorovye" ("Health") was launched in 2006, with a budget of more than $\$ 12.85$ billion as part of the country's National Development Strategy 2020.

Computerization and implementation of IT services is one of the main goals of The National Priority Project. The IT Health Plan is synchronized with the overall program of health development to 2020 and is supposed to create a unified state information system in the health sector by 2020. By 2018, 95\% of citizens are expected to have an electronic medical record. With the growth of consumer spending and an increase in government funding in healthcare, the long-term outlook for Russian healthcare providers and medical manufacturers is very positive in Russia. In 2013, a remote record and scheduling system was established for visiting doctors (United Medical Information and Analytical System of Moscow - "EMIAS").

\subsection{Opportunities and barriers for mobile healthcare development}

In Russia, the proportion of the elderly in the general population ( $>65$ years) is growing at $\sim 2 \%$ a year while the overall population is shrinking at $\sim 0.3 \%$ year on year. Meanwhile, a rising incidence of chronic diseases (heart disease, stroke) indicates a steady shift in the disease profile of the country [8]. There is an increase in the volume of medical data considering the growth in the number of patients. The amount of patient information is usually huge. It includes images and scanned documents, family history, healthcare records, diagnoses, treatments, and studies on the individual. This information comes from multiple sources and there is no generic database storage system.

After initial disarray in the last months of 2008, the economic downturn provoked a shift to use of the Internet [9]. Considering the ubiquity of cellular networks, smartphones and similar devices, experts forecast growth in the role of mobile technology and online medicine in the near future in Russia. Moreover, this trend will contribute to the excess of sales of mobile devices 
over PCs. It should be noted that Russia is the fastest growing Internet economy in Europe and occupies one of the leading places in the world [10]. The Russian Internet web audience in the beginning of 2016 amounted to $66.5 \mathrm{M}$ users [11] ( $~ 57 \%$ of the Russian population) the biggest audience in Europe, coming 5th after China, the USA, Japan and India. Yet, there are still many adults and young people who would appreciate the social and economic benefits of mobile technology but are unable to access it. According to analysts, in Russia there are more than 700,000 physicians and about half of them are actively using computers. More than 150,000 of them regularly seek information on the Internet and use social networks to address professional issues and improve their skills.

Certain difficulties hinder the establishment of an upto-date healthcare system in Russia. A number of barriers need to be broken down in order to ensure proper communication between different stakeholders, connecting providers, physicians, patients, clinics, government, etc. Many Russian doctors are very concerned lest a patient get access to his entire medical history and will draw the wrong conclusions. In addition, such healthcare systems should suppose personal data protection.

Russian healthcare is striving to deliver better and more efficient healthcare, and technology is an increasingly important component of strategies for achieving this. However, concerns persist regarding security and transparency. Most cloud players in Russia do not explain how they implement their security measures. According to a Ponemon Institute study conducted in 2015 , the amount of fraud and data loss of medical information increased from $20 \%$ to $50 \%$ over the last five years globally [12]. The lack of transparency makes it difficult for enterprises to assess the security risks, and this significantly inhibits the adoption of this approach by large enterprises. The issue could be due to inadequate implementation of security measures or the lack of appreciation of concerns over security that large enterprises have; neither is acceptable for enterprises that want to deploy cloud for mission-critical applications.

Russia does not have the required regulatory base and needs to provide targeted government-backed funding with a specific focus on remote medical services and their integration into the existing healthcare programs. A major issue with data processing lies in the fact that patient information is stored in different objects, information is being lost or concealed through the fault of the patient or the doctor, while there are no personalized analytics.
According to the Association for the Development of Medical Information Systems [13], the key constraints on Russia are the lack of a clear government policy in the sphere of computer-based information systems for healthcare, a funding deficit at medical establishments, flagging industry and lack of communication with society. The status of electronic documents remains undefined, so that doctors are forced to keep records in both hard and soft copies.

Recently Russia adopted a national standard [14], requiring that the patient be provided with access to his/her electronic case record. However, the only legally valid document is still the hard copy of a medical record. At the same time, the law already recognizes the validity of an electronic signature, and the Health Ministry plans to lobby respective regulatory changes which would help validate any electronic document with an e-signature.

As key stakeholders in the mobile healthcare business, mobile operators face significant challenges, such as the lack of resource commitments from government and health authorities and an unclear idea of what mobile Health involves and what the key applications are. There might be a great potential for mobile operators, but considerable investment is also required. Currently no Russian mobile operator is willing to take social responsibility and invest proactively in development of the mobile healthcare market. According to J'son research [15], all three Russian telecom operators have already started in 2010-2012 to sign partnership agreements with health service providers. However, cellular operators are in waiting mode, looking forward to monetize the services on data transactions and SMS after the whole system is in place and generates revenue streams from mHealth.

\subsection{An overview of Russian solutions for mobile and digital healthcare}

Creating an integrated mobile solution with global growth potential and sufficient functionality, capable of attracting a large number of users, is not a myth but a reality. What is needed is to design the details of its integration with other existing information technologies and medical solutions, get the market potential evaluation right, find a user niche, as well as take into account all the applicable legal and security-related aspects.

The outstanding case of a proven current service in Russia is "Med@rchive" (www.Medarchiv.ru), a single platform for managing information on the patient's health, with a mobile application available for the pa- 
tient. The service provides access to a personal health card, which it is sufficient to get once. It makes it possible to preserve the history of an illness throughout the life of the patient. The service allows the accumulation of all the disparate data in a secure cloud storage, and provides a personal health services calendar, electronic interaction and consultation with doctors and drug and physiological monitoring

Other well-known projects in Russia include "SMSmame" (https://SMSmame.ru, an innovative educational service for pregnant women and young mothers), the mobile application "Donor" (https://Donor.ru, helps to know where and who requires blood donations), "Button of Life" or "Life Button" (https://knopka24.ru/, medical social panic button for the elderly, adults and children with disabilities).

One of mobile solutions that should be mentioned is the "Alive Heart and Activity Monitor" system (http:// www.alivetec.com/), developed by Alive Technologies (Australia) in cooperation with the Moscow State University. It is used for the diagnosis and monitoring of chronic heart disease. The Alive Heart Monitor is a wireless health monitoring system for screening, diagnosis and management of chronic diseases, and for consumer health and fitness.

The "Medicine" system from 1C (www.med.1c.ru) should be specifically noted. It has a very broad array of subsystems and client services. All solutions are built on 1C's unified technology platform. The 1C product line offers a specialized system of (food accounting and nutrition management program for medical and rehabilitation facilities that helps assess the appropriateness of energy values and nutrient levels and supports a natural level of consumption.

The National Research University Higher School of Economics is continuing to develop its Automatic System of Distance Healthcare Monitoring (ASDHM) (https://www.hse.ru/org/hse/iit/ithmc/). The goal of the ASDHM is to improve and extend the patient's quality of life for people with chronic diseases. Remote health monitoring technologies - devices that gather a patient's health data and relay it to a care provider - have been the subject of much study in recent years and this project is a first step on this direction.

The Russian Ministry of Health and Ministry of Social Development organize an annual competition for developments in Public Health called the "Best Medical Information System". Russian software developers have presented numerous solutions since 2011, but they were mostly aimed at supporting the workplace of doctors or organizing the paperwork of clinics. The results of analysis show that the majority of the solutions were directed at the B2B segment, while services to patients were very limited. Only about $10 \%$ of the healthcare systems are geared to online or mobile services with a real focus to patient's health.

In the near future, there are plans to launch a mobile service for drug identification in Russia. This service will provide citizens with information regarding any medicinal drugs within a few seconds. To use the system, the person should install on his mobile phone special software that can be downloaded free of charge. To obtain information about drug authenticity and medical uses a picture with a drug barcode should be scanned by the application

In 2016 emergency physicians working in rapid response cars are expected to be equipped with tablet computers integrated into the United Medical Information and Analytical System of Moscow ("EMIAS").

Talking about the prospects of mobile health development in Russia, three possible scenarios can be expected. The first is the development of mobile technologies from independent ecosystems (partnerships of digital startups, producers of mobile healthcare devices, commercial medical organizations, etc.) and their integration in the medical community and industry. This would be the obvious evolution of the industry in accordance with worldwide market trends. There would be the question of penetration of new mHealth services to the mass users. Without state subsidies such services might be quite expensive and not affordable for the majority of people. The state involvement is highly demanded.

The second scenario supposes we shall overcome all the barriers described above and develop a nationalbased program that includes personal healthcare medical recording and access to mHealth services on the national level. This cannot be expected in the shortterm.

The last possible scenario that should be mentioned is forcing the mHealth development by "Big Pharma" companies operating in Russia and worldwide. These companies are usually focused on cooperation with local medical institutions and associations, with constant communication with patients (via medical representatives and doctors) and might be also interested in medical research and mHealth development in order to provide customers with more personalized medical services and treatment, early diagnostics, bio technologies, smarter medical devices and services. 


\section{Conclusion}

In conclusion, it should be said that in Russia, despite many challenges, there are a lot of opportunities for the development of online and mobile healthcare applications. This should start with the establishment of a data repository (centralized or decentralized) for managing patients' health records and appointments with doctors and continue with advanced functions of personal health watch, systematic healthcare treatment, with patients becoming more advanced users of all available medical services in the country. There are still difficulties such as a lack of professional doctors and inability to use up-to-date and costly technologies and smartphones for patients, geographical distance and lack of $3 \mathrm{G} / \mathrm{Wi}$ Fi coverage in remote geographical districts. However, the trend is positive. Each year new technologies and systems appear, the awareness of citizens is increasing and the demand for such services is growing.

\section{References}

1. American Hospital Association (2014) Trendwatch Chartbook 2014. Trends affecting hospitals and health systems. Available at: http://www.aha. org/research/reports/tw/chartbook/2014/14chartbook.pdf (assessed 05 May 2016).

2. Tsvetkova L.A., Kuznetsov P.P., Kurakova N.G. (2014) Otsenka perspektiv razvitiya mobil'noy meditsiny - mHealth na osnovanii dannykh naukometricheskogo i patentnogo analiza [Evaluating perspectives of mobile healthcare development - mHealth based on scientific and patent analysis]. Doctor and Information Technologies, no. 4, pp. 68-79 (in Russian).

3. Cox A. (2010) Mobile healthcare opportunities monitoring, applications \& mHealth strategies 2010-2015. Juniper Research Whitepaper, no. 07.

4. Shrestha R.B. (2012) Mobility in healthcare and imaging: Challenges and opportunities. Applied Radiology, no. 9.

5. Levy D. (2014) Emerging mHealth: Paths for growth // PwC. Available at: https://www.pwc.com/gx/en/healthcare/mhealth/assets/pwc-emerging-mhealth-full.pdf (assessed 05 May 2016)

6. Safavi K., Ratli R. (2015) Healthcare IT Vision: Top5 eHealth Trends // Accenture. Available at: https://www.accenture.com/ acnmedia/ Accenture/Conversion-Assets/Microsites/Documents20/Accenture-Healthcare-Technology-Vision-2015-Infographic.pdf (accessed 05 May 2016).

7. Pai A. (2013) Flurry: Millennials use health and fitness apps more than other age groups. Available at: http://mobihealthnews.com/23117/millennials-use-health-and-fitness-apps-more-than-other-age-groups (accessed 05 May 2016).

8. Varlamova M.A, Sinyavskaya O.V. (2015) Portret pozhilogo naseleniya Rossii [Elderly people portrait in Russia]. Demoscop Weekly, no. 627628. Available at: http://www.demoscope.ru/weekly/2015/0627/demoscope627.pdf (accessed 05 May 2016) (in Russian).

9. Komissarova T.A., Andreas F. (2012) The impact of market reforms and economic conditions on marketing in Russia. International Studies of Management \& Organization, vol. 41, no. 4, pp. 51-64.

10. Grebennikov S., Logunova O., Petukhova S., et al. (2016) Ekonomika Runeta: Issledovanie ekonomiki rynka Internet-servisov i kontenta v Rossii 2014-2015 [Economy of Runet. Research of economy of Internet services and content market in Russia 2014-2015]. Available at: https:// www.hse.ru/data/2015/12/16/1134402660/RUNET15_Booklet_A4_PREVIEW\%20\%25281\%2529.pdf (accessed 05.05.2016) (in Russian).

11. Rozhkova A., Borisova S.,Zolotukhina T. (2015) Internet v Rossii: Analiticheskiy byulleten' [Internet in Russia: Analytical bulletin]. Issue 52. Winter 2015-2016. Moscow: InFOM (in Russian).

12. Korolov M. (2016) Meditsinskie dannye stali pokhishchat' chashche [Medical data is stolen more often]. Open Systems. Available at: http:// www.osp.ru/news/articles/2016/20/13049283/ (accessed 16 May 2016).

13. Sheyan I. (2014) Vybor sdelan [The choice is done]. Computerworld Russia, no. 10, p. 6 (in Russian).

14. GOST R 52636-2006: Elektronnaya istoriya bolezni. Obshchie polozheniya [Electronic healthcare record. Fundamentals]. Available at: http:// www.gostedu.ru/385.html (accessed 05 May 2016) (in Russian).

15. J'son \& Partners Management Consultancy (2013) Rynokmobil'noymeditsinyv Rossii ivmire:osnovnye tendentsii iprognozy [M-Health market in Russia and worldwide: main tendencies and forecasts]. Available at: http://www.json.ru/poleznye_materialy/free_market_watches/analytics /rynok mobilnoj mediciny v rossii_i_v mire osnovnye tendencii i prognozy/ (accessed 05 May 2016).

\section{Мобильное здравоохранение: Перспективы в России}

\section{С.М. Авдошин}

кандидат технических наук, профессор, руководитель департамента программной инженерии Национальный исследовательский университет «Высшая школа экономики»

Адрес: 101000, г. Москва, ул. Мясницкая, д. 20

E-mail: savdoshin@hse.ru

\section{Е.Ю. Песоцкая}

кандидат экономических наук, доцент департамента программной инженерии

Национальный исследовательский университет «Высшая школа экономики»

Адрес: 101000, г. Москва, ул. Мясницкая, д. 20

E-mail: epesotskaya@hse.ru 


\begin{abstract}
Аннотация
В статье рассматривается возможность использования мобильных технологий и сервисов в сфере здравоохранения, а также потенциал их развития в России. В рамках исследования проанализированы текущие глобальные тренды с изучением отдельных примеров решений в области мобильного здравоохранения. Проанализированы этапы формирования российской государственной медицинской системы, для того, чтобы понять основные этапы становления, достижения и сложности при формировании системы, такие как безопасность, доступность и функциональность. Рассмотрены основные барьеры и препятствия по развитию среды мобильного и электронного здравоохранения в России, чтобы понять перспективы мобильного здравоохранения. Принимая во внимание то, что информационные технологии играют крайне важную роль в области медицины, проведен анализ существующих информационных систем и разработок, рассмотрены несколько примеров систем. В итоге предложены три различных сценария дальнейшего развития мобильного здравоохранения в России. При формировании сценариев учтены как существующие барьеры в области здравоохранения в России, так и основные мировые тренды - такие как, например, персонализация сервисов или сокращение затрат на медицинские услуги.
\end{abstract}

Ключевые слова: система здравоохранения, мобильное здравоохранение, информационные системы диагностики здоровья, персонифицированная электронная медицинская карта, медицинская информационная система, мобильные услуги и сервисы, информационные технологии.

Цитирование: Avdoshin S.M., Pesotskaya E.Yu. Mobile healthcare: Perspectives in Russia // Business Informatics. 2016. No. 3 (37). P. 38-44. DOI: 10.17323/1998-0663.2016.3.38.44.

\title{
Литература
}

1. Trendwatch Chartbook 2014. Trends affecting hospitals and health systems // American Hospital Association. [Электронный ресурс]: http://www.aha.org/research/reports/tw/chartbook/2014/14chartbook.pdf (дата обращения 05.05.2016).

2. Цветкова Л.А., Кузнецов П.П., Куракова Н.Г. Оценка перспектив развития мобильной медицины - mHеalth на основании данных наукометрического и патентного анализа // Врач и информационные технологии. 2014. № 4. С. $68-79$.

3. Cox A. Mobile healthcare opportunities monitoring, applications \& mHealth strategies 2010-2015 // Juniper Research Whitepaper. 2010. No. 07 .

4. Shrestha R.B. Mobility in healthcare and imaging: Challenges and opportunities // Applied Radiology. 2012. No. 9.

5. Levy D. Emerging mHealth: Paths for growth // PwC. [Электронный pecypc]: https://www.pwc.com/gx/en/healthcare/mhealth/assets/ pwc-emerging-mhealth-full.pdf (дата обращения 05.05.2016).

6. Safavi K., Ratli R. Healthcare IT Vision: Top5 eHealth Trends // Accenture. [Электронный pecypc]: https://www.accenture.com/ _acnmedia/Accenture/Conversion-Assets/Microsites/Documents20/Accenture-Healthcare-Technology-Vision-2015-Infographic.pdf (дата обрашения 05.05.2016).

7. Pai A. Flurry: Millennials use health and fitness apps more than other age groups. [Электронный pecypc]: http://mobihealthnews. com/23117/millennials-use-health-and-fitness-apps-more-than-other-age-groups (дата обращения 05.05.2016).

8. Варламова M.A., Синявская О.В. Портрет пожилого населения России // Демоскоп Weekly. 2015. № 627-628. [Электронный pecypc]: http://www.demoscope.ru/weekly/2015/0627/demoscope627.pdf (дата обращения 05.05.2016).

9. Komissarova T.A., Andreas F. The impact of market reforms and economic conditions on marketing in Russia // International Studies of Management \& Organization. 2012. Vol. 41, no. 4. P. 51-64.

10. Экономика Рунета: Исследование экономики рынка Интернет-сервисов и контента в России 2014-2015 / С. Гребенников и [др.] // РАЭК, НИУ ВШЭ. [Электронный ресурс]: https://www.hse.ru/data/2015/12/16/1134402660/RUNET15_Booklet_A4_ PREVIEW\%20\%25281\%2529.pdf (дата обращения 05.05.2016).

11. Рожкова А., Борисова С., Золотухина Т. Интернет в России: Аналитический бюллетень. Выпуск 52. Зима $2015-2016$. М.: ИнФОМ, 2015.

12. Королов М. Медицинские данные стали похищать чаще // Открытые системы. 2016. [Электронный pecypc]: http://www.osp.ru/ news/articles/2016/20/13049283/ (дата обращения 16.05.2016).

13. Шеян И. Выбор сделан // Computerworld Россия. 2014. № 10. С. 6.

14. ГОСТ Р 52636-2006: Электронная история болезни. Общие положения. [Электронный pecypc]: http://www.gostedu.ru/385.html (дата обрашения 05.05.2016).

15. Рынок мобильной медицины в России и в мире: основные тенденции и прогнозы // J'son \& Partners Management Consultancy. Июль 2013. [Электронный pecypc]: http://www.json.ru/poleznye_materialy/free_market_watches/analytics/rynok_mobilnoj_ mediciny_v_rossii_i_v_mire_osnovnye_tendencii_i_prognozy/ (дата обращения 05.05.2016). 


\title{
Budgeting automation
} in construction companies

\author{
Elena V. Kuznetsova \\ Associate Professor, Department of Business Analytics \\ National Research University Higher School of Economics \\ Address: 20, Myasnitskaya Street, Moscow, 101000, Russian Federation \\ E-mail:ev.kuznetsova@hse.ru
}

\begin{abstract}
The article focuses on corporate information systems intended for management accounting and budgeting (MAB) in project-oriented construction companies. The author argues that the successful implementation of such systems requires a comprehensive approach involving the development or the adaptation of MAB philosophy taking into account the software functionality and related business processes. The author demonstrates that ERP software is the most effective technological platform for corporate MAB systems of project-oriented companies. This is explained by the fact that the ERP systems have both sufficient functionality for project management automation and appropriate tools for management accounting and budgeting. Relying on this analysis, a comprehensive approach and appropriate solutions for developing corporate MAB systems in project-oriented construction companies are proposed. The methodological solutions proposed in the field of MAB design take into account the specific nature of a contractor who carries out construction projects for external customers.

In particular, the following methodological solutions are presented: establishing temporary projectbased profit centers in the construction company's financial structure; using administrative quasi-projects and the "direct costing" method for fixed overheads costing in certain departments; establishing temporary profit centers related to production departments (internal subcontractors). This paper also shows how such a financial structure may be used in the SAP ERP system relying on the end-to-end "project" attribute.

A budgeting structure with two versions of the corporate master budget is proposed. The first version of the structure is based on the contracting plans and the second - on the last approved project budget versions. The paper shows that monitoring implementation is necessary for both master budget versions.

The main assertions and results of the paper are applied in the implementation of a corporate MAB information system based on SAP ERP in a construction company. The results of the system'simplementation and operation have shown significant improvement in the key financial indicators of the company, including profits, rate of return and net cash flow.
\end{abstract}

Key words: information system, budgeting, management accounting, construction project management, project-oriented business.

Citation: Kuznetsova E.V. (2016) Budgeting automation in construction companies. Business Informatics, no. 3 (37), pp. 45-53. DOI: 10.17323/1998-0663.2016.3.45.53.

\section{Introduction}

I n times of economic depression, the construction industry appears to be extremely sensitive to decreasing demand and economic activity. Some construction projects are discontinued, while other projects face reduced investments. To survive in such conditions, construction contractors should curtail inefficient activities, avoid high-risk projects, and adjust their relationships with suppliers and customers. Inefficient construction contractors will have to withdraw from the market. 
Management accounting and budgeting information systems (MAB systems) are a powerful tool for increasing efficiency of both individual construction projects and the construction companies in general. Such systems provide real competitive advantages, facilitating project implementation planning and analysis, as well as the appropriate decision- making. However, MAB automation projects in the construction industry are not always successful. One of the main reasons for such a problem is the lack of a comprehensive approach to creating the MAB systems. Such an approach should involve MAB philosophy design (or adaptation) while taking into account the capabilities and features of implemented software and organization of relevant business processes. At present the problem of automated $\mathrm{MAB}$ organization in construction contractor companies has no integrated solution.

The main methodological aspects of the MAB are sufficiently developed and presented in academic literature. However, the authors of such papers usually consider MAB problems only for operating the business, investment projects, programs and portfolios. The paper [1] is perhaps the only book written by a Russian author that is fully dedicated to the MAB specifics in project-oriented companies. It deals with creating a budgeting system using the example of a telecommunication company that provides production, maintenance and delivery services and applies an MAB system based on "Intalev: Corporate Finance 2005" software.

Certain aspects of project budgeting are presented in international, national and industry related project management standards. For construction companies, the PMI Institute (Project Management Institute, USA) issued a Construction Extension to the PMBoK Guide [2]. This guide has sections dedicated to project cost and funds management. There are also a significant number of publications (including in Russian) on project management processes in construction, as well as on construction company management as a whole [3, 4]. Using the best practices and availability of the corporate project management standards are one of the success factors in MAB systems development. However, the standards and the academic literature in the area of project management and construction management cannot become a methodological base for the MAB setting due to their content specificity.

Therefore, we may conclude that at present the methodology of MAB automation in project-oriented companies that carry out construction projects for external customers has not been studied enough. In addition, MAB methodology cannot be developed without considering the information system used for budgeting and accounting processes. Practitioners have to solve these problems on their own or with the help of consulting company specialists. Moreover, the experience that has been gained in this area is not summarized and is not presented in publications.

Selection of an MAB information system is also related to specific practical problems. Special-purpose information project management systems that are well-known in Russia such as Microsoft Project, Oracle Primavera, CA Clarity PPM and Spider Project, have comprehensive functional capabilities for resource planning and project budgeting, scheduling and costing. However, such systems do not support corporatewide budgeting, do not provide a common information workspace of an enterprise, have insufficient functionality in the field of management accounting and therefore require additional expenditures for integration. In the author's opinion (confirmed by practice) ERP systems $[5,6]$ have comprehensive functionality for automating project management processes, as well as advanced tools for management accounting and budgeting. That is why such systems represent the most appropriate basis for implementation of corporate MAB systems in construction companies. SAP-based industry oriented solutions for construction companies are already available in the market [7, 8]. This paper proposes to take a comprehensive approach to MAB automation based on SAP ERP software. The solution is illustrated by the example of a contractor company that deals with engineering systems construction. The original methodological and software solutions proposed by the author may be applied in project-oriented construction companies which have implemented (or are planning to implement) SAP ERP system (or other ERP system with similar functionality).

\section{The main stages of creating an MAB system}

Implementation of an MAB system usually includes the following stages.

1. Preliminary stages:

a. The financial structure design - identification and classification of responsibility centers (RCs), determining relationships between them, assigning the RCs to the corporate management structure;

b. The budget model design - defining the budgets' content and the budgets' interrelationship;

c. The analytical items identification for the MAB detailing including the creation of the budgeting classifiera set of budgeting accounts for income, expenses and cash flows; 
d. The planning, consolidation and selection of analysis procedures for monitoring budget performance;

e. The internal corporate standards design for budgeting processes.

2. Implementation of an information system, which usually includes the system selection, design, development, testing, training and trial operation;

3. Adjustment of the procedures and standards according to the results of implementing the information system.

The preliminary stages are required during both spreadsheets-based budgeting set-up and budgeting automation based on ERP systems or on special solutions. In the latter case, the requirements related to formalization of the $\mathrm{MAB}$ processes and to designing the budgeting model are rising, because this directly affects the time and the cost of implementation. MAB methodology detailing at the preliminary stages allows us to generate the IT system functional requirements and to make the right choice of the technological platform. Inadequate attention to the issues of interrelations between the methodology and the technologies can lead to two undesirable extremes - either the functionality of the selected system will be insufficient or some part of its functionality appears to be unused [9].

Let us consider the most significant methodological solutions relating to a construction contractor which should be considered at the preliminary stage, and how these solutions can be implemented in practice using the selected information system.

\section{Design of the company financial structure}

The following features seem to be most important for designing the financial structure of a construction contractor company:

1. Projects are carried out by commercial departments (profit centers). The commercial departments can be divided by customer categories (e.g. state-owned companies, the banking sector, development business, etc.) or by project types and project specifics. Project managers and project supervisors (directors) are normally employees of the departments;

2. Projects are temporary profit centers subordinated according to the management hierarchy to the appropriate commercial department;

3. The profit of a commercial department is calculated as the sum of marginal contributions of all the projects after deducting the department's administrative overheads over a relevant period;
4. Both external and internal subcontractors - production departments are involved in execution of project works;

5. The cost center includes service and administrative departments, such as procurement, warehousing, bookkeeping, etc.

It is reasonable to use transfer prices in order to determine the cost of works performed by internal construction subcontractors. The main theoretical approaches to using transfer pricing in production companies are presented in paper [10]; their advantages and practical application in project-oriented companies - in papers $[1,11]$. While using transfer pricing, managers of production departments are responsible not only for costs, but also for revenues of their departments. Therefore, production departments are considered as virtual profit centers.

The financial structure of the company under consideration is shown in Figure 1. It is typical for companies that implement projects under contracts with external customers. Such a financial structure makes it possible to distribute the responsibility for the financial results of the company between its structural divisions.

The availability of temporary RC-projects and the internal subcontractors' participation in projects make the task of designing the financial structure for the MAB system rather significant. Further on, it will be shown how this task may be solved in an SAP ERP system using a minimal number of analytical points of view (POV).

\section{Budget model design}

There are the following basic budgeting business processes that are to be automated (Table 1). These processes are typical for project-oriented companies which execute projects under contracts with external customers.

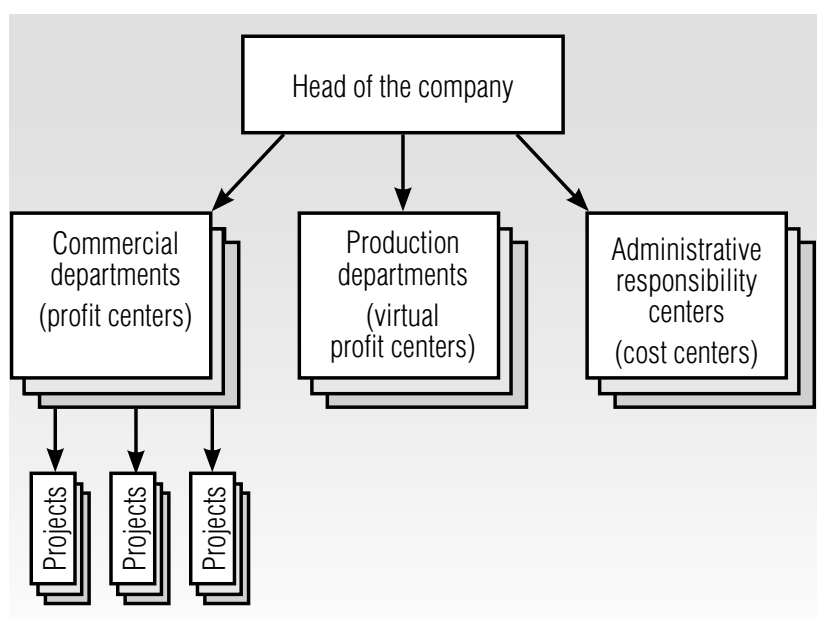

Fig. 1. Example of a project-oriented company's financial structure 
Table 1.

Basic budgeting business processes

\begin{tabular}{|c|c|}
\hline Process & Comment \\
\hline $\begin{array}{l}\text { Drawing up, coordinating and approving } \\
\text { contracting plans for the next budgetary year }\end{array}$ & $\begin{array}{l}\text { Revenue and expenditure budgets (REB) and cash flows budgets (CFB) are drawn up by commercial } \\
\text { departments for the next budgetary year without breakdown into individual projects. The contracting } \\
\text { plan may be considered as comparable to the sales budget used in operating businesses }\end{array}$ \\
\hline $\begin{array}{l}\text { Drawing up, coordinating and approving } \\
\text { overheads budgets for the next budgetary year }\end{array}$ & $\begin{array}{l}\text { REB and CFB are drawn up by cost centers, commercial profit centers and virtual profit centers } \\
\text { for the next budgetary year. Project overheads are taken into account in the project budgets }\end{array}$ \\
\hline $\begin{array}{l}\text { Drawing up, coordinating and approving project } \\
\text { budgets for their execution period }\end{array}$ & $\begin{array}{l}\text { REB and CFB are drawn up by project managers before signing contracts with the contractors. } \\
\text { Availability of agreed project budget makes it possible to start the project }\end{array}$ \\
\hline $\begin{array}{l}\text { Drawing up, coordinating and approving } \\
\text { corporate master budgets }\end{array}$ & REB and CFB for the company as a whole based on contracting plans \\
\hline $\begin{array}{l}\text { Drawing up budgets of commercial departments } \\
\text { and master budgets based on project budgets }\end{array}$ & $\begin{array}{l}\text { REB and CFB of commercial departments and company as a whole based on the most recent } \\
\text { approved versions of the project budgets. These budgets show the current contracting status; } \\
\text { they are neither coordinated nor approved }\end{array}$ \\
\hline Adjusting project budgets & $\begin{array}{l}\text { Can be performed many times during project implementation, at the discretion of the project manager } \\
\text { or project supervisor (director) }\end{array}$ \\
\hline Adjusting contracting plans & Performed from time to time as directed by the company, for example, every three or six months \\
\hline $\begin{array}{l}\text { Adjusting corporate master budgets based } \\
\text { on contracting plans }\end{array}$ & $\begin{array}{l}\text { Performed from time to time as directed by the company, for example, every three or six months. } \\
\text { Includes adjustment of the overheads budgets }\end{array}$ \\
\hline Preparing reports about execution of the budgets & At any time when it is necessary to obtain information \\
\hline
\end{tabular}

Therefore, the company budget structure consists of the following budgets:

$\checkmark$ corporate master budget (REB and CFB) drawn up based on contracting plans or most recent approved versions of project budgets;

$\downarrow$ contracting plans of departments and of the company as a whole (REB and CFB);

$\uparrow$ commercial departments' budgets (REB and CFB);

$\checkmark$ overheads budgets (REB and CFB);

$\checkmark$ project budgets (REB and CFB).

In accordance with SAP terminology, the project REB is usually called a "costs forecast" despite the fact that it also covers revenues. Below, for simplicity, the author will use the term REF. The interrelationship of the budgets listed above is presented in Fig. 2 (shaded rectangles show the differences between the two diagrams). REBs and CFBs are presented here by one block - "budgets".

The company budget structure does not include an investment budget. This is due to the fact that the issues of investment budgeting are addressed in full and detail in academic literature. In addition, the investment activities and investment projects budgeting have no specific features for construction companies.

The following essential features of the budget model should be mentioned:

1. Two versions of the master budget exist simultane- ously: based on contracting plans and based on the most recent approved versions of the project budgets;

2. Planning horizon and adjustment frequency of project budgets do not coincide with the planning horizon and adjustment frequency of the master budgets;

3. The project budgets "fill" the contracting plans. Therefore, it is necessary to monitor the performance of contracting plans (not only to monitor the project budgets).

Next, we will show how the tasks of the above budget model design can be performed using appropriate methodology and software.

\section{Determination of MAB analytical points of view}

The "Controlling" (CO) component of the SAP ERP system allows us to arrange the management accounting for cost and revenue elements, cost centers, business processes, internal orders, products, performance in separate market segments and profit centers (hereinafter the information presented in SAP Help Portal, http:// help.sap.com is used for description of the functionality of SAP ERP system). Business transactions in ERP systems of construction companies are normally performed by many employees who have different levels of competence and often - the lack automated accounting skills. Therefore, it is reasonable to use only the projects 


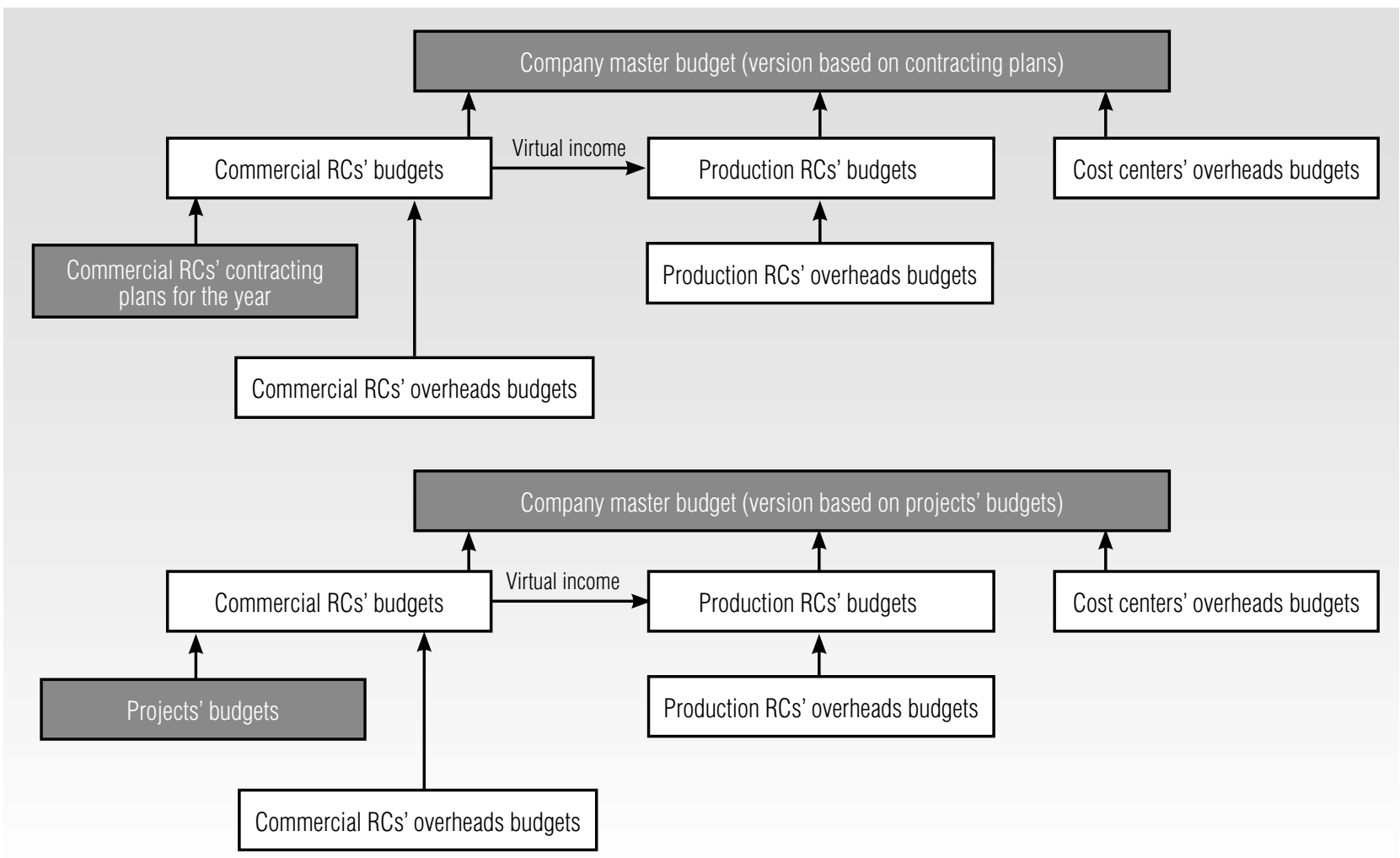

Fig. 2. The interrelationship of elements of the company budget model

and the cost and revenue elements as the main analytical items in income and expenses accounting. This significantly reduces the risk of data entry errors and data quality loss. To improve the budgeting and further 'planfact' control accuracy, it is reasonable to create budgets for the project as a whole, as well as for certain elements of the work breakdown structure (WBS). Under such an approach, WBS elements can be created for the project overheads accounting (such as mobilization costs).

Within the general approach to overheads accounting in the departments and the service and administrative units, it is proposed to use so-called "administrative projects". They are not consistent with the main criteria by which any activity may be considered as a project. However, the availability of such administrative projects enables us to solve the task of financial structuring of the company based on an end-to-end analytical item "project". The administrative project manager should be the head of the appropriate RC.

The costs and revenues classifier in SAP ERP is created using the management chart of accounts. It is necessary to use the cost and revenue elements "Revenues of internal divisions' services" and "Expenditures for internal divisions" respectively for internal subcontractors' works accounting. When preparing reports for the whole company, these account turnovers are eliminated.

To create and monitor CFB in an SAP system, the "Fund Management" (FM) component is used. Its main analytic items are funds centers (FC) and commitment items (CI), which are considered as cash flow accounts. CFB spending is represented by the accounting entries related with FC and CI. For description of FC, elements of the financial structure are used. In the example under consideration, after the creation of a new commercial or administrative project in the SAP system, a user creates the relevant FC. For this element, the corresponding project and its parent item in the FC structure are indicated. If necessary, for more detailed cash flow planning and accounting it is possible to create FCs not only for the whole project, but for certain WBS elements.

FCs are arranged hierarchically. The project FCs are "descendants" of the parent FCs associated with the appropriate departments. An example of FC hierarchy corresponding to the corporate financial structure is shown in Table 2. This table provides a three-level hierarchy FC structure where hypothetical alphanumeric symbols are used. As noted above, additional lower hierarchical levels can be created to improve the accuracy of planning and accounting. 
Table 2.

Example of FC guide hierarchy structure corresponding to the financial structure of the project-oriented construction company

\begin{tabular}{|c|c|c|c|c|}
\hline \multicolumn{3}{|c|}{ FC } & \multirow{2}{*}{ Name of FC } & \multirow{2}{*}{ Gomment } \\
\hline Level 1 & Level 2 & Level 3 & & \\
\hline \multirow[t]{23}{*}{ COMP } & & & Company & Company as a whole \\
\hline & ADC0MP15 & & $\begin{array}{l}\text { Company administrative } \\
\text { project } 2015\end{array}$ & Administrative project for company overheads accounting for 2015 (cost center) \\
\hline & ADSTOR15 & & $\begin{array}{l}\text { Storage area administrative } \\
\text { project } 2015\end{array}$ & $\begin{array}{c}\text { Administrative project for storage area expenditure accounting for } 2015 \\
\text { (cost center) }\end{array}$ \\
\hline & $\cdots$ & & $\cdots$ & $\begin{array}{c}\text { Administrative projects for other administrative and managerial departments } \\
\text { expenditure accounting for } 2015 \text { (cost center) }\end{array}$ \\
\hline & ADC0MP16 & & & $\begin{array}{l}\text { Company administrative project } 2016 \text { Administrative project for company overheads } \\
\text { accounting for } 2016 \text { (cost center) }\end{array}$ \\
\hline & ADSTOR16 & & $\begin{array}{l}\text { Storage area administrative } \\
\text { project } 2016 \\
\end{array}$ & $\begin{array}{l}\text { Administrative project for storage area expenditures accounting for } 2016 \\
\text { (cost center) }\end{array}$ \\
\hline & $\ldots$ & & $\cdots$ & $\begin{array}{l}\text { Administrative projects for other administrative and managerial departments } \\
\text { expenditure accounting for } 2016 \text { (cost center) }\end{array}$ \\
\hline & DEP1 & & Department 1 & Commercial department 1 (profit center) \\
\hline & & ADDP115 & $\begin{array}{l}\text { Department } 1 \text { administrative } \\
\text { project } 2015 \\
\end{array}$ & Quasiproject for department overheads accounting for 2015 (cost center) \\
\hline & & ADDP116 & $\begin{array}{l}\text { Department } 1 \text { administrative } \\
\text { project } 2016\end{array}$ & Quasiproject for department overheads accounting for 2016 (cost center) \\
\hline & & PR10115 & Project 1 Dep 12015 & Commercial project 1 (department 1) opened for 2015 (temporary profit center) \\
\hline & & PR10116 & Project 1 Dep 12016 & Commercial project 1 (department 1) opened for 2016 (temporary profit center). \\
\hline & & PR10216 & Project 2 Dep 12016 & Commercial project 2 (department 1) opened for 2016 (temporary profit center). \\
\hline & DEP2 & & Department 2 & Commercial department 2 (profit center) \\
\hline & & $\cdots$ & $\ldots$ & $\begin{array}{l}\text { Administrative and commercial projects of department } 2 \\
\text { (cost centers and temporary profit centers, respectively) }\end{array}$ \\
\hline & PR0D1 & & Production department 1 & Production department 1. Internal subcontractor (virtual profit center) \\
\hline & & RVPR115 & $\begin{array}{l}\text { Production department } 1 \\
\text { revenue project } 2015\end{array}$ & Project for department virtual income accounting for 2015 (virtual profit center) \\
\hline & & ADPR115 & $\begin{array}{c}\text { Production department } 1 \\
\text { administrative project } 2015\end{array}$ & Quasiproject for department overheads accounting for 2015 (cost center) \\
\hline & & RVPR116 & $\begin{array}{l}\text { Production department } 1 \\
\text { revenue project } 2016\end{array}$ & Project for department virtual income accounting for 2016 (virtual profit center) \\
\hline & & ADPR116 & $\begin{array}{l}\text { Production department } 1 \\
\text { administrative project } 2016\end{array}$ & Quasiproject for department overheads accounting for 2016 (cost center) \\
\hline & & PROD2 & Production department 2 & Production department 2. Internal subcontractor (virtual profit center) \\
\hline & & $\ldots$ & $\cdots$ & $\begin{array}{l}\text { Administrative projects and virtual income projects of Production department } 2 \\
\text { (cost centers and virtual profit centers, respectively) }\end{array}$ \\
\hline & & & & Other production departments (virtual profit centers) \\
\hline
\end{tabular}

Cash flow planning is done in SAP ERP by CIs. While creating the $\mathrm{CI}$ guide, it is necessary to take into consideration the possible adjustments of its elements derivation with cost and revenue elements for which cash flows are possible. Setting up such correspondence considerably simplifies the preparation of the CFBs based on the REBs.

For management accounting, short-term planning of works and materials (apart from those listed above), many other analytical items are used; for example, counterparts, contracts, materials, storage areas and some other items of the SAP system.

\section{Selecting planning, consolidation and analysis procedures for actual budget execution and their implementation in the SAP ERP System}

The Project Passport is the document describing the basic project parameters. It contains the basic information about works in progress, customer, contract with the customer, project team, monthly project REB and $\mathrm{CFB}$, as well as the calculation of absolute and relative marginal profit. 
For automating project budgeting processes within the proposed approach, the following methodological and program solutions are proposed and implemented:

$\diamond$ transaction for the Project Passport creation. This enables us to generate the project REB and the project $\mathrm{CFB}$, as well as to print out the Project Passport. The budgeting data is entered by period, by cost and revenue elements and related Cis, by WBS elements and corresponding FCs. To increase planning quality, it is also necessary to provide the possibility to enter budgeting data in different currencies converted into rubles according to the corporate exchange rates. This transaction is also used for budgeting administrative projects;

$\diamond$ user-specific project status profile, and also the automated Project Passport coordination (this process comprises sequential changes of users' statuses performed by authorized employees and top managers);

$\diamond$ storage of Project Passport versions in the SAP system. A Project Passport version is a fixed version of the $\mathrm{REB}$, the CFB and appropriate saved information about the WBS and project schedule, as well as saved information entered directly in the project fields;

$\diamond$ reports for monitoring the project REB and CFB. At that any approved version of the Passport can be used as a plan, at the user's discretion. Reports for comparing the Passport versions with each other are also used;

$\diamond$ automated process of project close-out.

More detailed project planning is performed using standard functionality of the "Project system" (PS) module. This module enables us to create the WBS and project schedule, to assign contractors to certain schedule tasks, as well as to plan the need for materials for the project works.

For the overheads accounting of commercial and production departments, as well as of company overheads, it is reasonable to apply the "direct-costing" method. Advantages of this method are discussed in the paper [12]. Its applicability in our case is due to the following reasons. Firstly, the project managers are responsible only for project marginal profit and have no means to manage overheads. The project teams' motivation system applied is also based on the project marginal profit figures. Therefore, from the managerial point of view, it does not make any sense to calculate total project cost including the distributed fixed overheads. Secondly, analysis of the company's accounting data over the previous years has shown that overheads of departments and service, administrative and managerial units are conditionally fixed.

For cost accounting using the "direct costing" method, appropriate administrative projects are used. At the end of each year, these projects in the SAP ERP system are closed, and costs allocated to these projects reduce the financial results of either appropriate departments (for profit centers and virtual profit centers) or the whole company (for cost centers).

Consolidation of budgeting data is provided by summarizing planning and actual data according to the FC hierarchy from the project budget level to the company level. Therefore, the actual REB and CFB represent the sums of budgeting figures of recent approved versions of commercial and administrative projects related to the appropriate parent RC and the time period. Standard SAP ERP reports are inconvenient for users; that is why more descriptive report forms are proposed for comparing the plan and actual data for departments and the whole company. At the end of the year, the last approved REB and CFB for all projects are copied as socalled "archive versions". If it is necessary to draw up a report on the budget execution for the previous years, the project budget archive versions of a relevant year are used. When drawing up reports for the current year, the last approved project versions are applied.

Contracting plans are implemented as the REB and CFB separate versions of commercial RCs. The contracting plan adjustment is performed by creating a new version of the REB and CFB. Contracting plans are approved outside the SAP system. In the SAP system the reports for comparing the contracting plan data with the last approved REB and CFB of relevant $\mathrm{RC}$ and with the actual data on its budget performance are implemented. For example, the RC head can get the following information on revenues:

Planned revenue according to the contracting plan for a year: 50 million rubles;

$\checkmark$ Planned total revenue for a year under signed contracts: 30 million rubles;

$\checkmark$ Actual revenue for a year: 18 million rubles.

\section{Regulating \\ business processes}

All proposed methodological solutions should be set down in internal regulatory documents of the company. Therefore, when creating the MAB system in a certain company such documents as "Regulations on project activity" and "Regulations on project budgeting", as well as about fifty standards for individual business processes (including MAB) should be issued. For suitable operation of the system, we recommend establishing a special department for methodological and functional 
system user support, as well as for the further regulation and to provide development and updates.

\section{Conclusion}

In this paper, the author proposes a comprehensive approach to creating corporate MAB information systems for the construction industry. The approach includes the basic solutions for methodological, technological and organizational components of such systems. On its basis, the corporate MAB system was developed, tested and implemented in a construction contractor company.

Within the comprehensive approach to creating the MAB system, original methodological solutions are developed and tested, relying on SAP software. These solutions include:

financial structure design based on "project" endto-end analytical items for such a company; $\diamond$ using administrative projects for the overheads MAB; $\diamond$ setting up and monitoring actual execution of master budgets based on both contracting plans and last approved project budgets;

$\diamond$ using transfer pricing for settlements with internal subcontractors and cost budgeting of their works based on transfer prices.

Implementation of the SAP-based integrated MAB system in a certain company has demonstrated that about in a year's time of system operation almost all the financial indicators (incl. profit, profit margin and net cash flow) were substantially improved. In addition, the application of transfer pricing made it possible to increase the overall performance of internal subcontractors.

The proposed comprehensive approach to creation of MAB systems in construction companies can significantly improve the majority of their financial indicators and increase their competitiveness.

\section{References}

1. Kubareva E.Yu. (2011) Byudzhetirovanie na proektno-orientirovan $\neg$ nom predpriyatii s matrichnoy strukturoy upravleniya: organizatsionno-metodicheskie osnovy [Budgeting in a project-oriented enterprise with matrix management structure: organizational and methodological fundamentals]. Moscow: DPK Press (in Russian).

2. PMBOK (2015) Rasshirenie dlya stroitel'noy otrasli k tret'emu izdaniyu Rukovodstva $k$ svodu znaniy po upravleniyu proektami (Rukovodstvo PMBOK) [Construction Extension to the PMBoK Guide]. Moscow: Olymp-Business (in Russian).

3. Tsvetkov A.V., Shapiro V.D., eds. (2013) Upravlenie konkurentosposobnost'yu v investitsionno-stroitel'nom biznese [Competitiveness management in investment and construction business]. Moscow: Omega-L (in Russian).

4. Kaplan E.L. (2009) Upravlenie stroitel'noy kompaniey [Construction company management]. Saint Petersburg: Giord (in Russian).

5. ERP dlya stroitel'stva: obzor [ERP for construction: an overview]. Available at: http://www.livepress.ru/tags/ERP_dlja_stroitel'stva (accessed 01 June 2016) (in Russian).

6. SAP ERP vnedrena $v$ stroitel'noy kompanii "MonArkh" [SAP ERP is implemented in MonArkh construction company]. Available at: http:// www.tadviser.ru/index.php/Проект:SAP_ERP_внедрена_в_строительной_компании_«онАрх» (accessed 01 June 2016) (in Russian).

7. Otraslevoe reshenie LANIT na baze SAP ERP [LANIT industry solution based on SAP ERP]. Available at: http://www.lanit-consulting.ru/_ files/texts/92/SAP_building.pdf (accessed 01 June 2016) (in Russian).

8. Korporativnaya sistema upravleniya na baze SAP (stroitel'stvo) kompanii Novacom [Corporate management system based on SAP (construction) of Novacom company]. Available at: http://nvcm.net/resheniya/korporativnaya_sistema_upravleniya_na_baze_sap/stroitel_stvo/(accessed 01 June 2016) (in Russian).

9. Isaev D.V. (2008) Byudzhetirovanie s primeneniem informatsionnykh system [Budgeting using information systems]. Management Accounting, no. 7, pp. 99-106 (in Russian).

10. Vakhrushina M.A. (2000) Vnutriproizvodstvennyy uchet i otchetnost'. Rossiyskaya praktika: problemy i perspektivy [Internal production accounting and reporting. Russian practice: problems and perspectives]. Moscow: Economics and Life (in Russian).

11. Kuznetsova E.V., Voronkova N.Yu. (2014) Transfertnoe tsenoobrazovanie kak instrument povysheniya rentabel'nosti proektnoy deyatel'nosti [Transfer pricing as a tool for increasing of project activities profitability]. Audit and Financial Analysis, no. 1, pp. 339-345 (in Russian).

12. Rasskazova-Nikolaeva S.A. (2009) Direkt-kosting. Pravdivaya sebestoimost'[Direct costing. Faithful cost]. Moscow: Knizhny Mir (in Russian).

\section{Автоматизация бюджетирования в строительных компаниях}

\section{Е.В. Кузнецова}

кандидат экономических наук, доцент кафедры бизнес-аналитики

Национальный исследовательский университет «Высшая школа экономики»

Адрес: 101000, г. Москва, ул. Мясницкая, д. 20

E-mail: ev.kuznetsova@hse.ru 


\section{Аннотация}

В статье рассматриваются особенности построения корпоративных информационных систем управленческого учета и бюджетирования (ИС УУиБ) для проектно-ориентированных строительных компаний. Показано, что для успешной реализации подобных систем необходим комплексный подход, предполагающий разработку или адаптацию методологии УУиБ с учетом возможностей и особенностей внедряемого программного обеспечения, а также соответствующую регламентацию бизнес-процессов. Также показано, что наиболее перспективной технологической основой корпоративных ИС УУиБ проектно-ориентированных компаний являются информационные системы класса ERP, обладающие как функциональностью для автоматизации процессов управления проектами, так и развитыми средствами ведения управленческого учета и формирования бюджетов. На основании результатов анализа предложен комплексный подход и основные решения для создания корпоративных ИС УУиБ проектно-ориентированных строительных компаний. Предложены оригинальные методологические решения в области организации УУиБ, учитывающие специфику деятельности строительного подрядчика, выполняющей проекты для внешних заказчиков.

В частности, к числу предлагаемых методологических решений относятся выделение в финансовой структуре строительных компаний временных центров финансовой ответственности (ЦФО прибыли), соответствующих выполняемым проектам, использование административных квазипроектов для учета условно-постоянных накладных расходов отдельных подразделений в сочетании с применением метода «директ-костинг», а также выделение временных ЦФО прибыли, соответствующих производственным департаментам - внутренним субподрядчикам. Показано, как данная финансовая структура может быть реализована в системе SAP ERP на основе сквозной аналитики «проект».

Предложена бюджетная структура, включающая в себя две плановые версии мастер-бюджетов компании: на основе планов контрактования и на основе последних по времени утвержденных версий бюджетов проектов. Показано, что необходимо организовать план-факт контроль выполнения обеих версий мастербюджетов.

Основные положения и результаты работы апробированы при внедрении корпоративной ИС УУиБ строительного предприятия ERP-класса на базе системы SAP ERP. Результаты внедрения и эксплуатации системы показали существенное улучшение основных финансовых показателей компании, в том числе прибыли, рентабельности и чистого денежного потока.

Ключевые слова: информационные системы, бюджетирование, управленческий учет, управление строительными проектами, проектно-ориентированный бизнес.

Цитирование: Kuznetsova E.V. Budgeting automation in construction companies // Business Informatics. 2016. No. 3 (37). P. 45-53. DOI: 10.17323/1998-0663.2016.3.45.53.

\section{Литература}

1. Кубарева Е.Ю. Бюджетирование на проектно-ориентированном предприятии с матричной структурой управления: организационно-методические основы. М.: ДПК Пресс, 2011. 248 с.

2. Расширение для строительной отрасли к третьему изданию Руководства к своду знаний по управлению проектами (Руководство РМВОК) / Пер. с англ. М.: Олимп-Бизнес, 2015. 232 с.

3. Управление конкурентоспособностью в инвестиционно-строительном бизнесе: Справ. пособие / Под ред. А.В. Цветкова, В.Д. Шапиро. М.: Омега-Л, 2013. 486 с.

4. Каплан Е.Л. Управление строительной компанией. СПб: Гиорд, 2009. 144 с.

5. ЕRP для строительства: обзор. [Электронный ресурc]: http://www.livepress.ru/tags/ERP_dlja_stroitel'stva (дата обращения 01.06.2016).

6. SAP ERP внедрена в строительной компании «МонАрх» [Электронный pecypc]: http://www.tadviser.ru/index.php/Проект:SAP ERP_внедрена_в_строительной_компании_«МонАрх» (дата обращения 01.06.2016).

7. Отраслевое решение ЛАНИТ на базе SAP ERP. [Электронный ресурc]: http://www.lanit-consulting.ru/_files/texts/92/SAP_building. pdf (дата обращения 01.06.2016).

8. Корпоративная система управления на базе SAP (строительство) компании Novacom [Электронный pecypc]: http://nvcm.net/ resheniya/korporativnaya_sistema_upravleniya_na_baze_sap/stroitel_stvo/ (дата обращения 01.06.2016).

9. Исаев Д.В. Бюджетирование с применением информационных систем // Управленческий учет. 2008. № 7. С. 99-106.

10. Вахрушина М.А. Внутрипроизводственный учет и отчетность. Российская практика: проблемы и перспективы. М.: Экономика и жизнь, 2000. 192 с.

11. Кузнецова Е.В., Воронкова Н.Ю. Трансфертное ценообразование как инструмент повышения рентабельности проектной деятельности // Аудит и финансовый анализ. 2014. № 1. С. 339-345.

12. Рассказова-Николаева С.А. Директ-костинг. Правдивая себестоимость. М.: Книжный мир, 2009. 256 с. 


\title{
Identification of the main problems of change management in software development companies: Research in the CEE region
}

\section{Denis S. Pashchenko}

Independent consultant in software domain

Address: 40/12, Nizhnya Krasnoselskaya Street, Moscow, 105066, Russian Federation

E-mail:denpas@rampler.ru

\begin{abstract}
Studying the typical problems in the software development process always has two approaches: the strategic view of the team of top managers focused on the IT business and the practical view of software project teammates - engineers, analysts, software quality assurance specialists. This article is dedicated to research of change management in software development processes in Central and Eastern Europe, including Russia, as one of software centers in this region. The research was carried out in the middle of 2014 and covers 78 experienced developers and analysts of the domain from 11 countries. The research has three sections: change planning, change implementation and consolidation of the new practices. The research is focused on key measurements and risks in all stages of change implementation from its planning up to analysis of results.

In the article, we present the project approach to change management with four stages: planning change, preparing the environment, change in details, change implementation. For each stage, we highlighted several typical problems and gave practical recommendations. Special attention was paid to research of long-term problems which cover the whole project of change management. These problems include: organizational resistance, changes goal's management, involvement of teammates and managers in the change management process. Practical recommendations in the final section of the article are focused on change management's best practices in the software domain as regards planning, delivery and consolidation of changes.
\end{abstract}

Key words: change management, improvement of software production, organizational resistance, software company.

Citation: Pashchenko D.S. (2016) Identification of the main problems of change management in software development companies: Research in the CEE region. Business Informatics, no. 3 (37), pp. 54-61.

DOI: 10.17323/1998-0663.2016.3.54.61.

\section{Introduction}

$\mathrm{T}$ The complexity of change management in software production is a well-known problem of the IT branch all over the world. There are a lot of cases when customers, top-managers of IT companies and common engineers have absolutely different points of view on the current level of product quality and process model of development. Convergence of those views and raising software quality often requires changes in production processes.

In the CEE region (Central \& Eastern Europe), part of the evolutionary process of process development, which went on worldwide in commercial software development from the 1970s and 80s, was missed at the end of 90s, when new and progressive ISVs (Independ- 
ent Software Vendor) and out-sourcing companies implemented modern models of processes based on the CMM (Capability Maturity Model) and RUP (Rational Unified Process). There also are a lot of IT companies in CEE countries and Russia which built their own process models of software production themselves, basing them on the habits of management, sometimes without taking into account end-customer expectations. On the other hand, during the last 10 years newly appearing software companies have tried to use agile and hybrid methodologies. In the author's research, the overall experience and opinions of 78 engineers from different kinds of software companies have been grouped and identified:

$\downarrow$ current experience of CEE software industry in production process improvement;

$\downarrow$ successful approaches in change management;

$\downarrow$ role of project management and formalization in change management;

$\downarrow$ key factors of resistance and cooperation of the participants of process improvement.

The view of engineers showed: how change management practices, measurements and results are estimated from production projects level by real participants of software development. Meanwhile, IT companies from the CEE region (and first of all from Russia) are playing an important role in the world market's software development and have a rapidly growing share [1]. This means that success in production and business improvement in these companies has a strong impact on the regional economics.

The IT branch is changing very rapidly in terms of technologies, automation tools, modern methodologies, educational standards and end-customer expectations. This means that production processes should be flexible and be capable of rapid change [2]. Proven approaches and practices in change management give additional chances for successful production, business improvement, and meeting customer requirements.

\section{Research method and process}

Research was conducted during the period from April to July 2014 by three rounds of Delphi study, which is one of the most relevant methods for long distance expert polling covering a big geographic area [3]. Seventy-eight experts from Central and Eastern Europe (including Russia, Ukraine and Belarus) have taken part in this research. All experts are real teammates in software delivery projects with a great deal of experience in the industry and almost all of them have a significant career and project history in leading software companies.

It would be correct to assume that the results of research in the middle of 2014 would be relevant for the middle of 2016 because business practices in change management in the software domain in the CEE-region have low volatility. By contrast, in China, India and the USA, we may see another situation: new approaches in software production and technologies are being implemented much faster and drive the business. This means that change management becomes more sophisticated and usual in the operations of IT companies. On the first round, the panelists have sent their opinion and answers on a list of questions with four sections:

$\diamond$ common questions about role of process formalization;

$\diamond$ planning of changes in production processes;

$\diamond$ process of implementation;

$\diamond$ consolidation of the results.

In the second round, the panelists received the leading opinion of the expert panel for all of the questions, thus giving them a chance to correct their opinion or just give a comment.

In the third round, the panelists gave additional information and comments, which helped to improve the Delphi study results and objectiveness.

The following table contains the numbers of active experts for each of the study's rounds (Table 1).

Table 1.

Activity of experts for rounds of the Delphi study

\begin{tabular}{l|c|c|c}
\cline { 2 - 4 } & Round 1 & Round 2 & Round 3 \\
\hline Active experts & 78 & 61 & 78 \\
\hline Percent of active experts & $100 \%$ & $78 \%$ & $100 \%$ \\
\hline
\end{tabular}

In round 2, we faced an obvious decrease of expert activity.

The following bullet points demonstrate different information about experts, their experience and geographical locations. The experience presented is usually most relevant for the same type of IT companies. Types of IT companies were present in Delphi Panel in the following ratio:

- $9 \%$ of the experts had experience at non IT companies with in-house development; 
- $11 \%$ of the experts have experience at software system integrators;

- $31 \%$ of the experts have experience at software vendors (ISV);

- $49 \%$ of the experts have experience from tailor-made software companies (including the out-sourcing model).

CIS-region geography of the research is as follows:

- 46\% of the experts are from Russia and Belarus;

- $26 \%$ of the experts are from the Balkan region (Serbia, B\&H, Moldova, Bulgaria);

- 15\% of the experts are from Central Europe (Czech Republic, Slovakia, Hungary);

- $13 \%$ of the experts are from Poland and Ukraine.

Most of the experts have been working in the software development area for a considerable number of years, so there are not many experts in the panel working in IT sector for less than 5 years:

- $7 \%$ experts are working in the software development area from 2 to 5 years;

- 44\% experts are working in the software development area from 5 to 10 years;

- $49 \%$ experts are working in the software development area for more than 10 years.

- $0 \%$ experts are working in software development area less than 2 years.

\section{Results}

\subsection{Planning and preparing for change implementation in software production model}

In this section we discuss core actions and preparations for change implementation including its initiation, planning, announcement, involvement of management and teammates in the activities.

Experts couldn't define a direct dependency between the whole company efforts, early planning and change management in software production. It seems that the process of innovations in development process model do not have a pre-defined regularity.

Question: Does the process of changes implementation in software production have a regular character?

$\checkmark 23 \%$ of experts: Yes, on the level of the whole company;

$\downarrow 36 \%$ of experts: Yes, on the level of each project;

$3 \%$ of experts: No, changes are implemented spontaneously;

$\checkmark 38 \%$ of experts: Partly it has regular character, partly it comes spontaneously.
The panel agreed that a major role is played by the project manager in initiating production process model changes but with some reservations. Firstly, in agile teams, the role of the PM is not so significant and everybody can initiate changes. Secondly, the quality direction in the company could have project managers as persons involved part-time.

Question: Who is the initiator for changes implementation in SW production model in most cases?

$\diamond 54 \%$ of experts: Project manager;

$\diamond 21 \%$ of experts: Quality / Process development direction;

$\diamond 21 \%$ of experts: Members in project teams;

$\diamond 5 \%$ of experts: Lead person of the company / software department.

In the experience of almost half of the experts in project teams, changes were announced right before implementation. Also in the practice of $70 \%$ of the experts, formal announcement by the Employer was a popular measure, commonly used for staff preparation. About $65 \%$ of the experts could remember "Involvement of analysts and engineers in production changes planning" in change management practices in their companies.

Almost 55\% of the experts said that from their experience the "buffer period", given for a software engineer's preparation for new production practices is about a few weeks. And only $25 \%$ of the experts met cases when preparation for new practices took less than one week. Some experts noticed that each project team should have its own plan of changes implementation even if it was prepared on the "whole company level". Of course, we are discussing only significant changes like implementation of requirements management or the "sprint releases" approach.

Experts defined the most popular measures of change's announcement in production processes as:

- special meetings with line and project managers (in practice of $99 \%$ of experts);

- announcement by CEO or CTO (in practice of $30 \%$ of experts);

- determination most often of reasons of changes in production processes;

- objective needs of change (in the practice of $64 \%$ of experts) in accordance with current economic results in the company or projects;

- following customer or auditor requirements and market's expectations (in the practice of $62 \%$ of experts). 
Despite different patterns in software development and formal equality in agile project teams, according to the opinion of the panel, exactly the project manager still has the biggest personal responsibility for the success of changes implementation in software production processes.

Question: Who has the biggest personal responsibility for the success of changes implementation in SW production processes?

- $44 \%$ of experts: Each project manager in his production project;

- $26 \%$ of experts: Head of software production department;

- 26\% of experts: All project teammates;

- 4\% of experts: Initiator of changes despite his job title.

\subsection{Change implementation in software development processes}

In this section, we discussed problems of change implementation, common methods, risks and priorities. The main idea of this section was to define the best approaches in practice to change implementation on the project level.

Experts summarize the most popular methods of practical change management in software companies:

$\downarrow$ verbal orders and supervision by the project manager (met in the practice of 59\% of experts);

$\downarrow$ publication of orders and instructions, changes in business processes (met in the practice of $57 \%$ of experts).

This means that on the project level all changes should be supported by the project manager, but also rebuilt business processes should prevent ignoring the changes.

Of course, automation of production processes in software development is one of the key features [4]. The panel saw a positive and significant role of automation tools in changes management.

Question: How does automation of software delivery processes support change implementation in the production model?

$23 \%$ of experts: Automation is not connected with changes implementation;

$8 \%$ of experts: Automation allows ignoring all changes in production processes;

$\diamond 64 \%$ of experts: Automation makes teammates follow all changes in production processes;
$5 \%$ of experts: Automation of processes could be circumvented and changes could be ignored.

Experts identified a list of strong problems, typical for change management and process standardization in IT companies. First of all, "Formal implementation without understanding of its sense and goals" (met in the practice of 77\% experts) and "Conflicts between goals of a project and goals of implementing changes" (met in the practice of 54\% experts). Experts also found that a "Sharp drop in the quality of software and/or release delivery schedule" is a strong risk in the practice of most IT projects.

There are a lot of organizational measures used to increase effectiveness of change management. But specific features of the IT branch require additional arrangements to overcome organizational resistance. Experts defined a few effecive meatures:

- explanatory work with suppressed elements (met in the practice of $61 \%$ of the experts);

- involvement of resisting staff in implementation of changes (met in the practice of $48 \%$ of the experts);

- positive motivation for accepting changes.

Motivation of involved staff is a key factor in change management, but not all measures can be used directly. The panel defined a list of common arrangements:

- inspiring and encouraging the use of new practices (met in the practice of $82 \%$ of the experts);

- public censure for failing to follow the implemented Standards (met in the practice of $31 \%$ of the experts).

Change management and production process standardization often meet an interesting contradiction, when changes interferes with current production goals and staff KPI. Experts do not much worry about this issue.

Question: How often are the goals of changes implementation more important than the current activity of producing the product of the project?

- $3 \%$ of experts: Very often;

- $31 \%$ of experts: Often;

- $59 \%$ of experts: Seldom;

- 7\% of experts: Never.

The panel also identified some typical costs for each project during change implementation:

- costs of quality and/or product delivery deadlines (met in the practice of $85 \%$ of the experts);

- worsening the internal climate in the project team (met in the practice of $31 \%$ of the experts); 
- part of staff is leaving the team / company (met in the practice of $27 \%$ of the experts).

This means that change implementation on the last stage of product delivery could be a real risk for common project success and on all stages needs a set of corrective actions.

\subsection{Changes consolidation and analysis of results}

Changes in the production model need a strong consolidation supported by all involved persons. In this section, experts gave their vision of effective measures of changes consolidation and analysis practices of final results in IT companies.

There are a few common and typical arrangements for changes consolidation:

$\downarrow$ audit from the project manager's side (met in the practice of $69 \%$ of the experts);

\ automation processes according implemented standards (met in the practice of $56 \%$ of the experts).

$\checkmark$ documenting changes in project artifacts (met in the practice of $49 \%$ of the experts);

encourage the use of new practices (met in the practice of $37 \%$ of the experts).

New implemented processes also need a regular control of execution by teammates. Experts defined a set of effective arrangements:

$\diamond$ audits from the project manager side (met in the practice of $60 \%$ of the experts);

$\diamond$ analysis of incidents after failures in the software product (met in the practice of $57 \%$ of the experts).

The panel shared their experience in change management and its results in their companies.

Question: Usually how successful do you reach the goals of significant change implementation in software delivery?

- $3 \%$ of experts: Almost all targets are lost;

- 46\% of experts: Part of the goals are lost, details vary;

- 46\% of experts: Achieved most of the goals;

- $5 \%$ of experts: The goals are achieved, and the results are superior to expectations.

Analysis of results is a crucial activity that helps in change management improvement and allows us to define all key parameters of internal process development in general. Of course, scheduling of this analysis is also important.

Question: When is analysis of changes implementa- tion in software delivery usually performed?

- $23 \%$ of experts: It may be on any schedule;

- $59 \%$ of experts: The analysis is performed a few months after changes implementation;

- $8 \%$ of experts: The analysis is performed only before planning the next changes;

- $10 \%$ of experts: Nobody cares about such analysis.

As one of the key ideas of research, change management should be convenient for teammates and its negative influence on production goals should be reduced as much as possible. Experts shared a vision of regularity of changes and in common agreed that for projects (or iteration of big projects) it is better to avoid implementing two significant changes in the software development processes.

Question: What time period is considered to be convenient and effective between implementation of two significant changes in the software development processes?

- $51 \%$ of experts: Better to avoid it in one project;

- $11 \%$ of experts: A few months;

- $15 \%$ of experts: A few weeks;

- $23 \%$ of experts: Hard to answer.

\section{Conclusion}

This part of the article is focused on an overview of the cycle of change management and results of research, demonstrating different aspects of each stage of cycle. The process of change implementation in the software production process model could be illustrated by the following diagram and was presented by the author from different perspectives $[5,6]$. In short, it's a spiral with four main stages:

$\uparrow$ planning change;

$\checkmark$ preparing the environment;

$\uparrow$ change in detail;

$\checkmark$ change implementation.

During all stages, the formal team of change management is working on updating and executing the change implementation plan and minimization of special risks, like organizational resistance, maintaining the trust of top and middle management and avoiding contradiction between goals of production and changes.

There is one iteration of the change implementation loop on the level of software production project (Figure 1). 


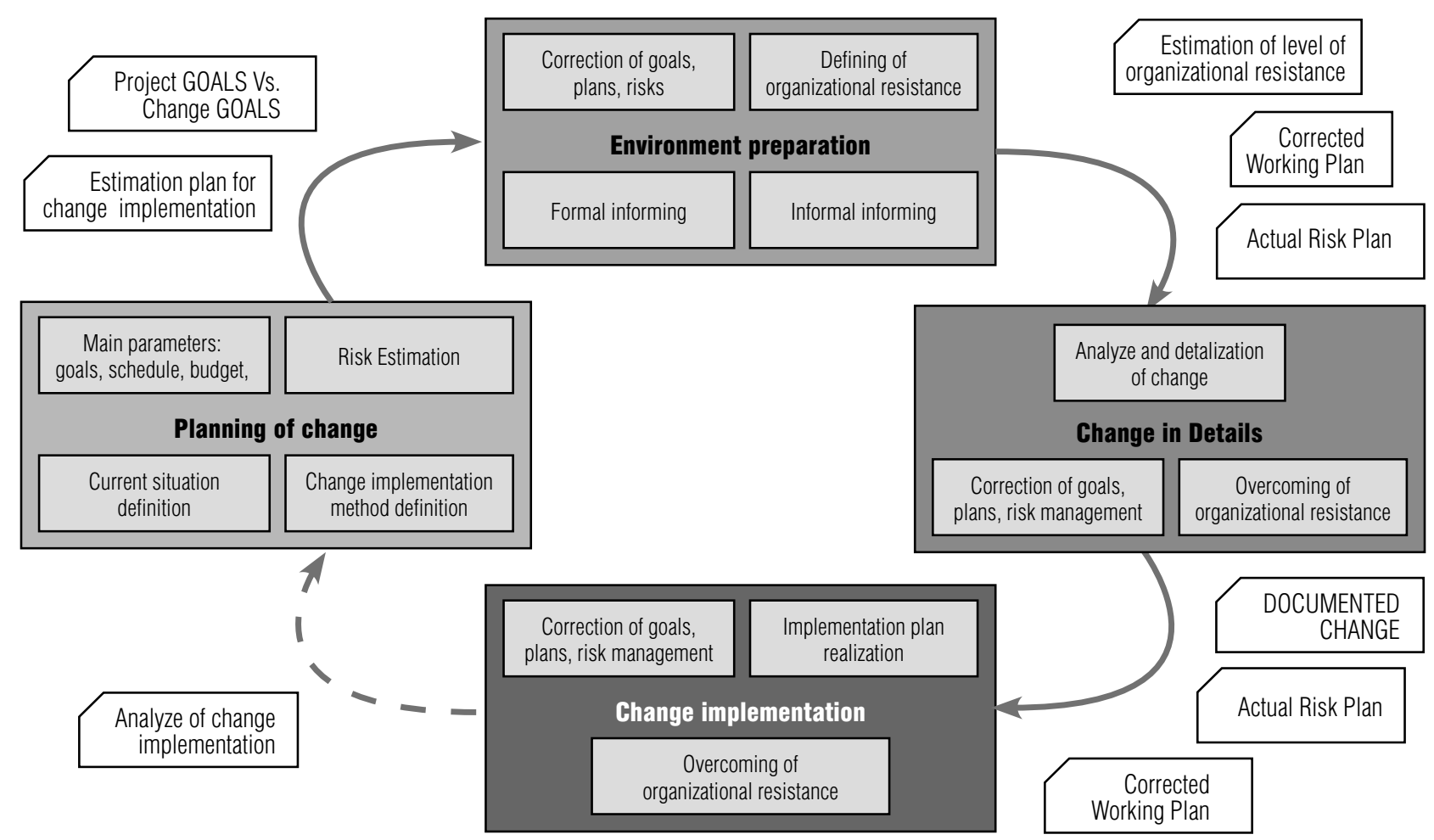

Fig. 1. Stages of iteration of change implementation cycle

The research sections cover all stages of iteration and are focused on special risks and aspects of each stage and the process as a whole.

In stages of planning and preparing the environment, experts defined a need of change implementation process formalization. The panel recommended using the same sets of documentation for an internal project of process improvement like for most of external software / consulting projects.

Based on the research results, the authors also recommend paying attention to the formal stage of planning, when the manager of this kind of internal project may spend time on risk management and planning important items:

\section{$\diamond$ additional time reserves;}

$\diamond$ involving external consultants in some stages and activities (like training or audits);

$\diamond$ all arrangements and actions aimed on the overcoming typical implementation problems;

$\diamond$ working with support and loyalty of the top and middle managers, which may help pass the critical points of the project.

There are two well-known problems in such kind of projects that may be envisaged in the planning stage: lack of time and lack of resources. Additional time reserves could help to mitigate the first risk, and involving top managers could help with the second. Support of the top managers (like CEO, CTO or COO) could be a strong helping factor, giving an additional chance for the project of software production process improvement to succeed. Involving the top managers in changes management on a high level may be the most valuable resource in this stage.

Experts also found that the project manager is the key person in change management on the project level, and this means that any team of change management should spend some efforts involving and keeping the loyalty of that level of management.

According to the view of the panel, informing staff about changes in the production process early occurs seldom, but is an effective measurement like kick-off meetings or engineer's involvement. Exactly line-managers and the project manager are in charge of these informational activities.

Changes implementation is not only a plan, but a set of documents, actions, reviews, etc. This Delphi study has shown that these arrangements are supported on different levels: in the current project, in software production department, on the level of the whole IT company. 
It's absolutely expected by the common engineers if automation of process makes everyone follow changes.

Changes implementation faces with a lot of risks and problems in IT companies. This Delphi study has demonstrated some of these problems, e.g. formal implementation without results and without its understanding by employees, contradiction between project and changes goals and even organizational resistance. Solving these problems requires from the internal project team a lot of effort and attention during all implementation stages.

The experts also defined a set of well-known risks that may be incurred during change implementation:

sharp drop in the quality of software and/or release delivery schedule;

$\checkmark$ drop of team's motivation and rise of conflicts inside project team.

Change implementation also provides a "Costs of quality and/or product delivery deadlines" that requires additional efforts in software quality and project management from the team.

Of course, the team of change management is trying to resolve these issues and research has demonstrated that "soft" methods are more relevant. Perhaps, this is because of the engineer's structure of our expert panel, but the most relevant arrangements looks like:

- explanatory work with suppress elements;

- involvement of resisting staff in implementation of changes;

- inspiring and encouraging the use of new practices.

"Rough" methods like "directive repression" or "fines" are not expected and are not widespread in IT companies. The author also could advise the use of only "soft" methods and nto be sparing of efforts in explanatory work at all stages of the change management loop.

Consolidation of changes is a crucial point in all kinds of business process reengineering. Experts be- lieve that exactly the project manager can effectively perform audit execution of new practices, estimate the results, adjust use of new practices in production project. This practically means that efforts of centralized audits should be aligned with needs of the project manager and the loyalty of the project manager should be kept on a high level even after formal change implementation.

From the research results, the author may also recommend formalization and documentation of the results of an internal project no matter what its results. This kind of report may be used in planning the future process improvement, or during the corrective actions in the next stage of changes implementation.

Experts from the engineers' environment are much more optimistic in their estimation of change implementation results from their experience than IT managers as seen in previous research of the author [7]. The expert panel agreed that in change management every subsequent attempt is more successful than the previous one; that is indirectly confirmed by the rationality of the set of cycles in process improvement.

Change management should be comfortable for project teams and not make engineers spend too much attention and time in production projects. The main idea is to reduce stress situations for the team and their needs to spend more efforts overcoming it while keeping high quality and speed of software development.

The research has shown the importance of process improvement and standardization that needs a planned and balanced approach for change implementation at all levels: a project, a software production department and the whole company. The panel responses, especially in consensus opinions, have demonstrated the need to consider all the factors of organizational resistance and teammate's involvement at each stage of a project involving changes implementation.

\section{References}

1. Software Russia (2012) Russian Software Industry Overview. Available at: http://www.software-russia.com/why_russia/industry_overview (accessed 25 May 2016).

2. DeCarlo D. (2004) eXtreme project management: Using leadership and tools to deliver value in the face of volatility. Jossey-Boss: Whiley.

3. Linstone H.A., Turoff M. (1975) The Delphi method: Techniques and applications. Reading: Addison-Wesley.

4. Pomeroy-Huff M., Mullaney J., Cannon R., Sebern M. (2009) The Personal Software Process (PSP) Body of Knowledge, ver. 2.0. Special report CMU/SEI.

5. Pashchenko D.S. (2012) Proektirovanie organizatsionnykh izmeneniy v IT-kompaniyakh s uchetom faktorov protivodeystviya [Design of organizational changes in IT companies taking into consideration resistance factors]. Management and Business Administration, no. 4, pp. 170-179 (in Russian).

6. Pashchenko D.S. (2014) Features of change management projects in Russian software development companies. Project and Program Management, no. 1, pp. 22-32.

7. Pashchenko D.S. (2014) Effektivnye praktiki vnedreniya izmeneniy v protsessakh razrabotki programmnogo obespecheniya na urovne proekta [Efficient practices of changes management in software development processes on project level]. Management and Business Administration, no. 4, pp. 166-174 (in Russian) 


\title{
Основные проблемы управления изменениями в компаниях, разрабатывающих программное обеспечение: Исследование в Центральной и Восточной Европе
}

\section{Д.С. Пащенко}

кандидат технических наук, МВА

независимый консультант в области разработки программного обеспечения

Адрес: 105066, г. Москва, ул. Нижняя Красносельская, д. 40/12

E-mail:denpas@rampler.ru

\begin{abstract}
Аннотация
Статья посвящена проблемам внедрения изменений и улучшений в компаниях, производящих программное обеспечение (ПО). Статья позволяет взглянуть на данный процесс не только на стратегическом уровне, что присуще менеджменту компаний, но и осветить практические проблемы, с которыми сталкиваются рядовые сотрудники проектных команд - разработчики, аналитики, специалисты по качеству ПО. Все выводы и заключения основаны на авторском исследовании, проведенном в 2014 году среди 78 экспертов из 11 стран Центральной и Восточной Европы, включая Россию, как один из центров разработки ПО в данном европейском регионе. Исследование было направлено на поиск решений актуальных проблем управления изменениями от этапа их планирования до анализа результатов.

В статье предложен проектный подход к управлению изменениями, включающий четыре стадии планирование, подготовка среды к изменениям, детализация изменений, внедрение и закрепление новых практик. Особое внимание уделено проблемам, которые сопровождают все стадии такого проекта: организационному сопротивлению, необходимости управлять целями изменений, вовлечению проектных команд в управление изменениями. Практические рекомендации, представленные в заключительной части статьи, отображают лучшие практики в отрасли разработки ПО на всех стадиях такого проекта.
\end{abstract}

Ключевые слова: управление изменениями, улучшение производства программного обеспечения, организационное сопротивление, софтверная компания.

Цитирование: Pashchenko D.S. Identification of the main problems of change management in software development companies: Research in the CEE region // Business Informatics. 2016. No. 3 (37). P. 54-61. DOI: $10.17323 / 1998-0663.2016 .3 .54 .61$

\section{Литература}

1. Russian Software Industry Overview. [Электронный ресурc]: http://www.software-russia.com/why_russia/industry_overview (дата обращения 25.05.2016).

2. DeCarlo D. eXtreme project management: Using leadership and tools to deliver value in the face of volatility. Jossey-Boss: Whiley, 2004.

3. Linstone H.A., Turoff M. The Delphi method: Techniques and applications. Reading: Addison-Wesley, 1975.

4. Pomeroy-Huff M., Mullaney J., Cannon R., Sebern M. The Personal Software Process (PSP) Body of Knowledge, ver. 2.0. Special report CMU/SEI, 2009

5. Пащенко Д.С. Проектирование организационных изменений в IT-компаниях с учетом факторов противодействия // Менеджмент и бизнес-администрирование. 2012. № 4. С. 170-179.

6. Pashchenko D.S. Features of change management projects in Russian software development companies // Project and Program Management. 2014. No. 1. P. $22-32$.

7. Пащенко Д.С. Эффективные практики внедрения изменений в процессах разработки программного обеспечения на уровне проекта // Менеджмент и бизнес-администрирование. 2014. № 4. С. 166-174. 


\title{
Overcoming expressiveness deficit of business process modeling languages ${ }^{1}$
}

\author{
Igor G. Fiodorov \\ Associate Professor, Department of Applied Information Technologies and Information Security \\ Plekhanov Russian University of Economics \\ Address: 7, Nezhinskaya Street, Moscow, 119501, Russian Federation \\ E-mail: Igor.Fiodorov@mail.ru
}

\begin{abstract}
Y. Wand and R. Weber have suggested that the ontological clarity of the modeling language can be evaluated by comparing the alphabet of this language with the constructs of top level ontology known as Bunge-WandWeber (BWW). According to them, one of the key success factors of using a given language is its ability to provide the users with a symbol set, which can directly reflect appropriate ontology concepts. However, the ontology is not limited to a thesaurus; it also covers the structure of relations between concepts. It may be assumed that the modeling language must be able to convey these relationships. Therefore, the approach of Y. Wand and R. Weber can be significantly enhanced if the structural relationships among BWW ontology concepts are studied. This paper also makes an attempt to extend the BWW ontology as applied to business process modeling, since in its current form it does not make it possible to represent logical operators and the temporal characteristics. We enhance the BWW ontology with transformations which change mutual properties, they correspond to logical operators. The interpretation of the event concept is modified such that it designates the moment in time when the object state changes. It is demonstrated that external events are connected to each process operation. Thus, the items of temporal logic: the moment in time and time interval between two consecutive events are added. The investigation of relations among enhanced BWW ontology concepts made it possible to substantiate five perspectives of the process model and identify formalisms used for their description, i.e. informational entity-relation diagram; behavioral - state transition diagram; transformational - dataflow diagram; temporal event graph; logical - ordinary Petri nets. Multiple research shows that process modeling languages and notations are not able to display immediately all BWW ontological model concepts, but only part of them. Moreover, the authors of these researches focus their attention on a percentage ratio of modeled and unmodeled concepts, calculate a relative degree of deficit, redundancy, excess and overload. For overcoming the deficit, this paper proposes to model a business process not in one notation but in several correlated diagrams, so that each diagram reveals separate perspectives, and all together they form a coordinated, integrated process description.
\end{abstract}

Key words: business process modeling, Bunge-Wand-Weber ontology, expressiveness deficit, process model perspectives.

Citation: Fiodorov I.G. (2016) Overcoming expressiveness deficit of business process modeling languages. Business Informatics, no. 3 (37), pp. 62-71. DOI: 10.17323/1998-0663.2016.3.62.71.

\section{Introduction}

A variety of languages and notations, namely: UML [1], BPMN [2], EPC [3], ebXML [4], BPEL [5], Petri Nets [6] are used for business process modeling. Hence, the question often arises to carry out a comparative analysis in order to determine which is bet- ter-suited for business process modeling [7]. Y. Wand and R. Weber have suggested that the ontological clarity of the modeling language can be evaluated by comparing the alphabet of this language with the constructs of the top level ontology known as Bunge-Wand-Weber (BWW) [8]. One of the key success factors of using a given language is its ability to provide the users with a symbol set (modeling

${ }^{1}$ This work was executed with the support of the Ministry of Education and Science of Russia within the basic part of government task No. 2014/122, reference number 2966. 
primitives), which can directly reflect appropriate ontology concepts (abstracts). They identify the following correspondence options between an alphabet of the modeling language and a set of ontology concepts (Figure 1):

$\downarrow$ construct equivalence: each symbol of an alphabet can be associated with exactly one concept;

$\downarrow$ construct deficit: separate concepts have no corresponding symbol;

$\downarrow$ construct excess: the ontology concept cannot be associated with any symbol;

$\checkmark$ construct redundancy (synonymy): one concept can be represented directed in several symbols;

$\checkmark$ construct overload (homonymy): several concepts correspond to one symbol.

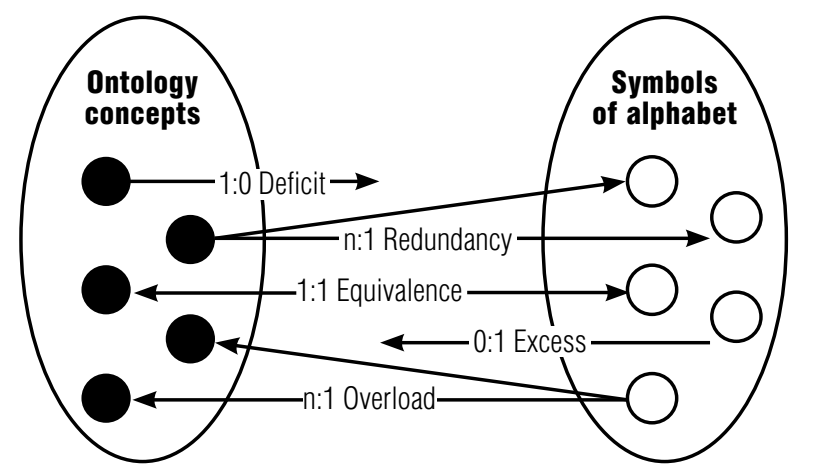

Fig. 1. Relationship between modeling language primitives and BWW ontology concepts

The essence of the approach proposed by Y. Wand and $\mathrm{R}$. Weber consists in checking an equivalence of two sets, i.e. symbols of an alphabet and ontology concepts. The research demonstrates that all known business process modeling languages have an expressiveness deficit [9], so that overcoming this deficit is an important and urgent task. However, the ontology is not limited to a thesaurus, it also covers the structure of relations between concepts [10]. It may be assumed that the modeling language must be able to convey these relationships. Therefore, the approach of Y. Wand and R. Weber can be significantly enhanced if the structural relationships among BWW ontology concepts are studied. This paper also makes an attempt to extend the BWW ontology as applied to business process modeling, since in its current form it does not make it possible to represent logical operators and the temporal characteristics.

\section{Enhanced BWW ontological model}

The model proposed by Y. Wand and R. Weber is based on the ontology proposed by M. Bunge [11]. The world is made up of things, which are usually treated as a "separate object of the tangible world with relative independ- ence, objectivity and stability of existence" [12], therefore, in what follows the term "object" will be used as a synonym of a thing. The object has properties which are its attributes; so a property cannot have properties. The object state is defined as a set of all values of all its attributes at a given time. Moreover, not all states are considered as acceptable and not all transitions between states are considered lawful [13]. The object state transits due to transformation, which is always implemented by a predetermined rule called the transformation law. Transformation can be interpreted as a work changing the object, or an operation being performed on the object.

Let us pay attention to the fact that M. Bunge differentiates between the intrinsic object properties inherent thereto and distinguishing one entity instance from another one (for example, the color and shape characterize each object on an individual basis) and mutual properties, which characterize one object relative to another (for example, distance is a property of a pair of objects). Speaking about the transformation, M. Bunge has in mind a change of intrinsic properties of the object. We will interpret the transformation in a more comprehensive sense, and also consider a change of mutual properties. For example, the process operation changes the intrinsic properties of the object, while the logical operator in the process diagram route the object along one of several processing paths, changing its relative position, whereas the intrinsic properties of the object remain unchanged. Therefore, by partitioning the transformations which change the intrinsic properties of the object and the transformations which modify the mutual properties, we complement the ontology with a capability to represent logical process operators [14].

The fact of changing the object state is called an event, irrespective of the cause of occurrence. Meanwhile, it remains not quite clear what is the difference between the event and the state. In current interpretation the event has a meaning "for this reason" and represents a cause-andeffect relationship: the next operation can start because of the completion of the previous one. Therefore, it emerged that the terms state and event are hard to differentiate. The event interpretation proposed by us is different from the interpretation proposed by M.Bunge. By the definition of E.A. Babkin, an event is something that is happening at some instant per saltum, step-wise and is considered as a state change of a certain object [15]. Yu.N. Pavlovsky interprets an event as an instant in time designating a change of the object states [16]. Therefore, we will link an event with a moment in time when a change of state of a certain object occurred; it has the meaning of "afterwards" later in the chronological order. Thus, an internal event establishes the fact and the moment in time when the ob- 
ject passed into the following state and is ready for execution of the next operation. The occurrence of an internal event is insufficient for the beginning of execution of the next operation. In case of an interactive operation the execution begins following the interference of the actor and the latter is treated as an external object relative to the system. If the operation is automatic, then it start after a signal from the external control device. Therefore, external event represents the fact and moment in time of changing the state of the object external to the system, which initiates the execution of the operation and record the moment when the transformation began. Thereby, the terms of temporal logic are added to the ontology: a moment in time and time interval between two consecutive events [14]. The time interval between the occurrence of an internal event indicating readiness to processing, and an external event indicating the real beginning of work will be interpreted as the waiting time, the time interval between the occurrence of an external event indicating the beginning of work and internal event indicating the end of processing will be interpreted as the execution time. An external event not only initiates the execution of the process operation, but can also stop it. For example, a customer placed an order - this event initiates the process, and if the customer canceled the order, further processing may not be reasonable. The external event may imply the occurrence of an abnormal situation and require special processing. Thus, we enhanced the BWW ontology, added it with transformations which change mutual object properties they correspond to logical operators, changed the event concept interpretation such that it designates the moment in time when the object state changes, and demonstrated that the external events are related to each process operation.

An important conclusion that can be made from the analysis of BWW enhanced ontology is in specifying a set of concepts. Among these are (Figure 2):

$\diamond$ the object to be processed - it has an internal structure describing a set of inherent properties of the object;

$\diamond$ transformations changing intrinsic properties of the object that result in a change of its state;

$\diamond$ transformations which route the object, but do not change its state;

$\diamond$ internal events which designate a moment in time when the object is ready for execution of the next operation;

$\diamond$ external events which designate a moment in time when operation starts.

Now we have to analyze the relationships between the individual concepts of the ontology.

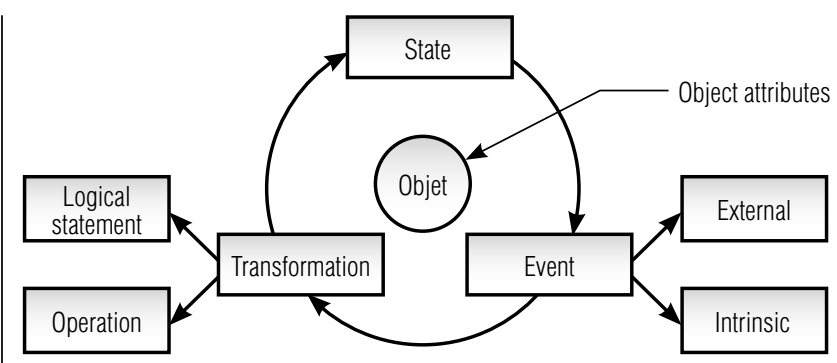

Fig. 2. Basic concepts of the process model

\section{Structure of BWW ontological model}

Let us consider what formal models enable us to describe relationships between separate concepts of the BWW ontology. The adapted ontological model includes six concepts, and respectively we have to consider a graph having vertexes of six types. In this graph (Figure 3), vertex sets of different types do not overlap; there are no arcs linking vertexes of similar type - it can be classified as sextuple. One have to note that vertex sets are linked only pair-wise: state with event, event with transformation, transformation with state. It can be seen that the above-listed relationships can be reflected by virtue of well-known modeling formalisms: the entity-relationship diagram (ER) [17], state diagram (STD) [18], data flow diagram (DFD) [19], event graph [20], and Petri nets [21]. Let us consider how the above diagrams describe relationships among pairs of concepts. We will consider only basic formalisms which have no extensions. We have to note what each diagram is capable of modeling and what it uses as a reference to another diagram.

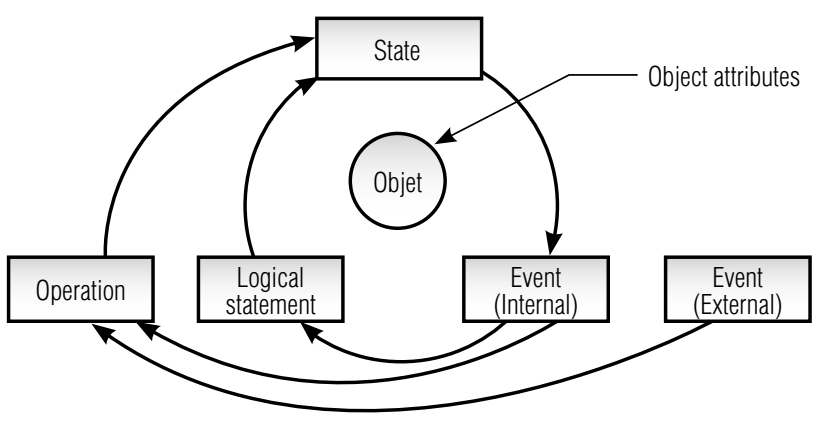

Fig. 3. Sextuple graph describing the BWW ontological model

\subsection{Entity-relationship diagram (ER)}

The entity-relationship diagram (ER) is used to describe information objects, its attributes and relationships between them. Retrieving the basic concepts of the domain area, one can find objects to be processed, each of 
which forms an appropriate process. The diagram uses the terms: entity, which is taken to mean any distinctive object, and attribute which is taken to mean a named inherent (property) of the entity [17]. The object state is determined by values which take its attributes. We can associate each named object's state with a definite set of attributes and their values. Therefore, the ER diagram models the object and its structure.

\subsection{State transition diagrams (STD)}

The state transition diagram is a traditional approach to describe the behavior of an object. It is customary to distinguish control and computational states [22]. For example, a control state "work is in progress/completed" reflects the status of a separate process operation. The computational state is associated with an object, it reflects success or failure of the operation. For example, operation "check the bill" can result in a success the bill is accepted, or a failure - the bill is rejected. The subject of our discussion is the computational state of the object. Inasmuch as many variables and control flows can exist within a large application program, it is conventional to specify the state variables [23]. To simplify the analysis, the changes of one state variable are considered at any specific time, which determines the state of the entire system [22].

The state diagram shows transitions between the acceptable states of the object. It uses named object states, but does not display values of relevant attributes - this information can be obtained by reference from the ERdiagram. The state diagram does not allow us to model transformations which result in a state transition; instead, it contains a reference to the data flow diagram, where the relevant information is available.

\subsection{Data flow diagram (DFD)}

The data flow diagram describes the processing of information objects [24]. It is conventional to call it transformational, since it depicts the operations which transform the input data to output, but does not show those actions which do not change the object [25], so that it does not make it possible to model logical operators. Let us note that the diagram indicates a logical name of transformation, and as such the transformation algorithm is contained in the mini-specification which describes transformation of concrete attribute of the object. A DFD diagram shall be consistent with STD and ER diagrams: the initial and final states of the object shall differ in particular by those attributes which are changed by this transformation. DFD does not contain information on the moment in time when transformation can be initiated; for this purpose a reference to the event graph is used, which will be addressed below.

The question as to whether a data flow diagram is formal depends on the method of description of the minispecification converting inputs into outputs. If the minispecification can be defined in a strict mathematical form, the model is considered to be formal. In our case, the mini-specification can be described formally using the notion of a target value of an object and its attributes. As a result of transformation, the object shall pass into a target state, which is characterized by a certain set of target values of the attributes of this object. If transformation succeeds all target values are achieved, this means that the target state of the object is obtained, and if the target value is not achieved, then it is considered as a failure. Therefore, it is possible to abstract from specific values and describe the transformation formally using Boolean logic.

\subsection{Event graph}

The event graph shows the temporal relationship between the events [20]. Its nodes represent moments in time when the object changes its state. The events can be internal, associated with changes of the object under control and external ones associated with changes of other objects, which are outside of the process' control. The diagram arcs represent a sequence of events and, therefore, the event diagram depicts a temporal relationship of consequence of events. If we associate the arc length with the time interval which passes between two consecutive events, we will get a Gantt chart. For example (Figure 4), event E0in reflects the moment of completion of the previous operation: the object is ready for execution of the next operation, however, it does not begin immediately, but with some delay - let us call it a waiting time of the execution. External event E1ex, which is associated with the external control device initiates the execution of the next operation. The fact of completion of the next operation is reflected as internal event Elin: the object is ready for execution of the next operation; it will be again in a waiting state until external event E2ex occurs. The Gantt chart is depicted in the same figure.

\subsection{Petri nets}

It is commonly supposed that Petri nets enable us to model the execution behavior of the process [26]; however, this is not quite true, inasmuch as simple Petri nets have a limited expressiveness and are not able to 


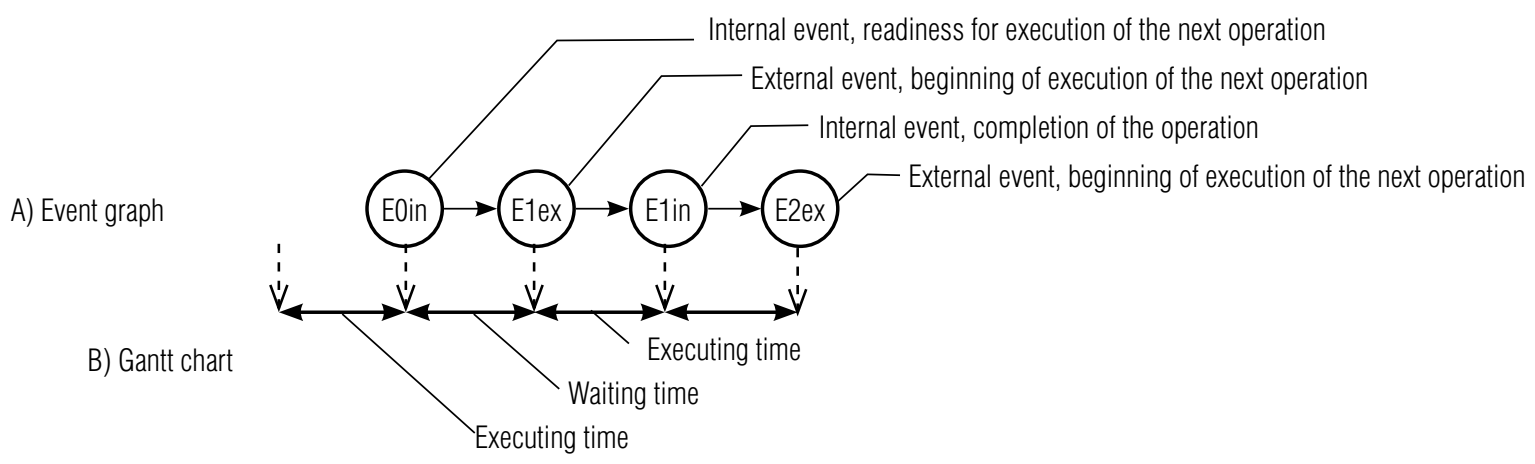

Fig. 4. Event diagram and Gantt chart

reflect the object's state. The graphical representation of the Petri net is a bipartite directed graph containing two types of nodes - places and transitions interrelated by arcs, where the nodes of the same type cannot be directly connected. Places can accommodate tokens capable of moving through arcs via transitions. In case of process modeling, a tokens is associated with a certain material object or information entity. The transition is associated with the work or operation, it moves the token from one places to another. The place is passive, it does not change and does not move the token, only keeps it between two transitions. The state or marking of Petri net at any moment in time is determined by distribution of tokens over the places. The token doesn't have state, so the change of the objet in response to operation is not analyzed. We have to note that transitions of ordinary Petri nets cannot reflect the transformation algorithm, since they do not contain a mini-specification; they can not represent transformation duration, because they occur immediately, and positions do not reflect the object state. The tokens reflects the current "spatial position" of the "control point" on the process chart as a result of routing by logical operators. Thus, ordinary Petri nets are not capable of modeling the behavior, but are suitable for modeling the process logic. This task is urgent, because a certain combinations of simple logical operators may result in collisions preventing a normal termination of the process. For example, as consequence of chaining "OR" (split) with "AND" (join) a deadlock occurs, the process stops and cannot be terminated [27].

\subsection{Structure of relationships between ontology concepts}

It may be concluded that relationships between the ontological concepts of the BWW model are described by five diagrams. Those familiar with engineering drawings are aware that a model of a mechanical part has three projections. Thus, in the absence of at least one of them the drawing is incomplete, and it is impossible to fabricate a part. The diagrams presented can be considered as a projections of the process model: each displays separate relations between ontological concepts, and all together they form the complete model. We have to distinguish the following perspectives and formalisms used for their description, namely, informational - the entity-relationship diagram; behavioral the state diagram; transformational - the data flow diagram; temporal - the event graph; and logical - the ordinary Petri nets. Table 2 presents process's perspectives and proposes formal models; symbol "M" shows a parameter modeled by an appropriate diagram, and symbol " $R$ " is a parameter which is used as a reference to another diagram.

Table 1.

What enables us to model the diagrams

\begin{tabular}{|c|c|c|c|c|c|c|c|}
\hline \multirow{2}{*}{ Doncept } & \multirow{2}{*}{ 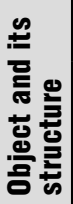 } & \multirow{2}{*}{ 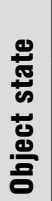 } & \multicolumn{2}{|c|}{ Operation } & \multicolumn{2}{|c|}{ Event } & \multirow[b]{2}{*}{ 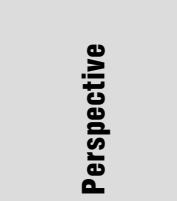 } \\
\hline & & & 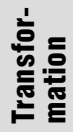 & 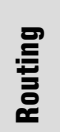 & 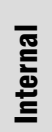 & $\begin{array}{l}\text { 퐇 } \\
\text { 离 }\end{array}$ & \\
\hline ER & M & - & - & - & - & - & Informational \\
\hline STD & $\mathrm{R}$ & $M$ & $\mathrm{R}$ & - & - & - & Behavioral \\
\hline DFD & R & $\mathrm{R}$ & M & - & - & - & Transformational \\
\hline Petri Net & - & - & $\mathrm{R}$ & $M$ & - & - & Logical \\
\hline Event Graph & - & $\mathrm{R}$ & - & - & M & M & Temporal \\
\hline
\end{tabular}

\section{Structural analysis of business processes modeling languages}

A large body of research reveals that process modeling languages and notations are not capable of reflecting BWW ontological model concepts all at once, but only part of them. Moreover, the authors of investigations focus their 
attention on a percentage ratio of modeled and unmodeled concepts, calculate a relative degree of deficit, redundancy, excess and overload. Table 2 shows the results of similar research [9]. One is compelled to ask: to what extent a language having a $10 \%$ of deficit is better than another language having a $15 \%$ expressiveness deficit?

\section{Comparative analysis of modeling languages}

\begin{tabular}{c|c|c|c|c}
\hline \multirow{2}{*}{$\begin{array}{c}\text { Modeling } \\
\text { notation }\end{array}$} & \multicolumn{4}{|c}{ Relative degree } \\
\cline { 2 - 5 } & Deficit & Overload & Redundaney & Excess \\
\hline BPMN 1.0 & $51 \%$ & $35 \%$ & $28 \%$ & $25 \%$ \\
\hline BPML 1.0 & $29 \%$ & $65 \%$ & $28 \%$ & $3 \%$ \\
\hline EPC & $3 \%$ & $62 \%$ & $43 \%$ & $28 \%$ \\
\hline WSCI 1.0 & $29 \%$ & $49 \%$ & $18 \%$ & $8 \%$ \\
\hline ebXML 1.01 & $15 \%$ & $13 \%$ & $14 \%$ & $5 \%$ \\
\hline BPEL 1.1 & $32 \%$ & $49 \%$ & $13 \%$ & $6 \%$ \\
\hline
\end{tabular}

Let us suggest that a requirement of equivalence of language symbols set and BWW ontology concepts is too strict, that the overload, redundancy and excess make the modeling language unsuitable for modeling. However, the expressiveness deficit of the language is acceptable, because it can be overcome. Table 2 shows a comparison of the EPC and BPMN expressive power in order to represent various perspectives of the process model. Both notations do not model the structure of information object; thus, they do not reflect the information perspective. The symbol "event" in EPC notation reflects a state acquired by an object as a result of execution of the process operation. It makes it possible to show a sequence of state transitions and thus model objects behavior; however, no place for state mapping is foreseen in BPMN notation. Both notations represent names of the operations which transform the information object, but it is necessary to refine them using mini-specifications, to specify the properties to be changed in order to achieve a target state. The EPC diagram contains no means to indicate time intervals; therefore, it does not represent a temporal perspective - such means are available in BPMN notation. Both diagrams enable us to reflect logical process statements. In summary, it can be seen that none of the business process modeling notations are able to represent the process model perspectives all at once, but only part of them. In other words, both notations have an expressiveness deficit.
Table 3.

\section{Comparative analysis of EPC and BPMN notations expressiveness}

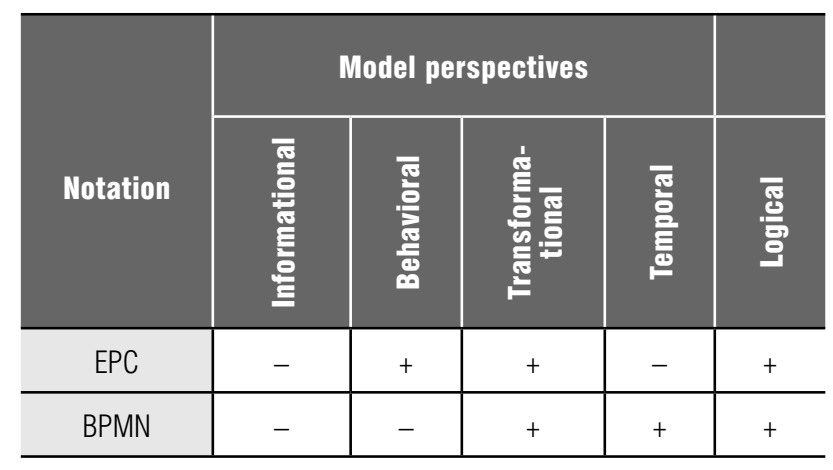

In order to overcome the deficit, this paper proposes to model the business process not in one notation, but in several coordinated diagrams, so that each diagram identifies separate perspectives of the model, and all together they form an integrated description. For example, EPC notation should be supplemented with the information model and Gantt chart, and the model in BPMN notation should be supplemented with the information model and the state diagram. Diagrams depicting individual perspectives of the process model shall be well coordinated. For example, the transformational perspective should describe a change of only those properties that characterize an appropriate target state of the object.

\section{Discussion}

The idea that the process model consists of several perspectives was addressed by different researchers. For example, a well-known $\mathrm{Za}-$ chman model includes six perspectives [28]. Architecture CIMOSA identifies four perspectives: functional, informational, resource, organizational [29]. The integrated model of ARIS information systems addresses four perspectives, where three informational, organizational and functional - being considered as basic, and the choice of the fourth perspective is determined by the choice of modeling objective, i.e. for the information system modeling a resource representation is used, and for business modeling the management perspective is applied [30]. The proposal formulated by B. Curtis includes four perspectives: functional, behavioral, informational, organizational [18]. It can be seen that a number of perspectives in various researchers is different, so an objective comes up concerning justification of a list of model perspectives. 
Let us agree to distinguish the terms "process" and "business process". The difference is as follows. According to $\mathrm{M}$. Bunge, the process is a history of a certain object which change its states due to the execution of transformations initiated by events. Let us consider what sense we put into the term "process" when we add the word "business". Firstly, we mean that the controlled object is an informational one, otherwise, if the object is tangible, one should speak of a manufacturing process. Secondly, we assume that there is some technology interpreted as a method of obtaining a reproducible result of a required quality for a specified time with reasonable utilization of economic resources. The purpose of a business process is a reproducible output which can be achieved by formalizing the way of performing the operations. Thirdly, the business process require some economic resources, and if their consumption is higher than planned, we should speak about the procedural violation. The enhanced BWW ontology addressed by us in this paper includes five perspectives: informational, behavioral, transformational, temporal and logical, with each perspective having its own formalism. It does not contain concepts characterizing the economic result and taking into account the economic resources spent, so it describes the process model but not business process.

Let us turn to the above assumption that the expressiveness deficit of the process modeling language can be overcome. If some business processes modeling notation does not allow us to reflect individual perspectives, we can talk about an expressiveness deficit of a relevant language. The deficit can be overcome by modeling a process in several correlated diagrams so that each diagram depicts separate aspects, but all together they give a complete and integrated representation of all its aspects. Certain perspectives should be consistent, so that references show links between diagrams.

The result obtained is of great practical importance. The software modeling environment like ARIS and UML include plenty of notations, and the analyst is invited to make a choice, taking into account his personal preferences. It is left aside that having selected the basic modeling notation the analyst should complement it with such diagrams which all together cover all perspectives of the process model.

The approach proposed in the paper is generally consistent with the suggestions made by E. Jordan, who within the structural modeling method proposed sequential modeling in three diagrams DFD,
STD and ER [31]. E. Jordan did not set a goal to design a real-time system, so his structural method omits the temporal aspect and Gantt chart; the business logic is not modeled, so no Petri nets are missing. A selection of perspectives by E Jordan is not theoretically justified. Since we consider the most general case, we added our model so as to take into account all the relationships between the concepts. Similar comments are true if we consider the executable $\mathrm{XUML}$, since it uses the same set of diagrams as E. Jordan [32].

\section{Conclusion}

The novelty of the analysis performed in this paper is in the adaptation of Bunge-Wand-Weber ontological model for process modeling. Additional concepts are identified and a new interpretation is given to them. The relationships between concepts are studied, five perspectives of the process model: informational, behavioral (state), transformational, logical and temporal are theoretically justified. For each perspective, a formalism is defined. A difference between the process model and business process model is demonstrated.

A practically important result is obtained, proving that none of the known business process modeling languages is capable to represent all BWW ontological concepts at once, but only part of them. Thus, all known modeling notations have an expressiveness deficit. This paper proposes a method for overcoming the deficit consisting in the use of an integrated process model which includes a number of perspectives, each showing some aspects of the process model, and all together they form a complete, coordinated representation.

The result explain why the executable business process model requires rather much programming. Firstly, the executable model in BPMN notation is not capable of representing separate process model perspectives. Secondly, it can happen that perspectives are insufficiently integrated with each other at a model level. Both shortcoming has to be compensated with an additional software code. A method is proposed to overcome the ontological expressiveness deficit which consists in process modeling in several diagrams, so that each of them "covers" separate perspectives of the process model, and all together they enable us to create a complete and comprehensive integrated description of the process. That will eliminate a need in additional programming. 


\section{References}

1. Opdahl A., Henderson-Sellers B. (2002) Ontological evaluation of the UML using BWW model. Software and Systems Modeling, vol. 1, no. 1, pp. 43-67.

2. Recker J., Rosemann M., Krogstie J. (2007) Ontology versus pattern-based evaluation of process modeling languages: A comparison. Communications of the Association for Information Systems, vol. 48, no. 20, pp. 774-799.

3. Green P., Rosemann M. (2000) Integrated process modeling. An ontological evaluation. Information Systems, vol. 25, no. 2 , pp. 73-87.

4. Green P., Rosemann M., Indulska M. (2005) Ontological evaluation of enterprise eystems interoperability using ebXML. IEEE Transactions on Knowledge and Data Engineering, vol. 17, no. 5, pp. 713-725.

5. Green P., Rosemann M., Indulska M., Manning C. (2007) Candidate interoperability standards: An ontological overlap analysis. Data \& Knowledge Engineering, vol. 62, no. 2, p. 274-291.

6. Rosemann M., Green P., Indulska M., Recker J. (2009) Using ontology for the representational analysis of process modelling techniques. International Journal of Business Process Integration and Management, vol. 4, no. 4, pp. 251-265.

7. Fiodorov I.G. (2011) Sravnitel'nyy analiz metodov modelirovaniya biznes-protsessov [Comparative analysis of business processes modeling methods]. Open Systems, no. 8, pp. 28-30 (in Russian).

8. Wand Y., Weber R. (2002) Research commentary: Information systems and conceptual modeling - A research agenda. Information Systems Research, vol. 13, no. 4, pp. 363-376.

9. Recker J., Rosemann M., Indulska M., Green P. (2005) Business process modeling: A maturing discipline? // BPM Center Report BPM-06-20, 2005 37. Available at: http://bpmcenter.org/wp-content/uploads/reports/2006/BPM-06-20.pdf (accessed 15 January 2014).

10. Nayhanova L.V. (2005) Osnovnye aspekty postroeniya ontologiy verkhnego urovnya i predmetnoy oblasti [Main aspects of construction of high level ontologies and subject area]. Internet Portals: Content and Technologies. Moscow: Informika, Prosveshchenie, pp. 452-479 (in Russian).

11. Bunge M. (1977) Treatise on basic philosophy ontology I: The furniture of the world. Vol 3. Boston, MA: D. Reidel Publishing Company.

12. Uemov A.I. (1963) Veshchi, svoystva i otnosheniya [Things, properties and relations]. Moscow: USSR Academy of Sciences (in Russian).

13. Soffer P., Wand Y. (2005) On the notion of soft-goals in business process modeling. Business Process Management Journal, vol. 11, no. 6, pp. 663-679.

14. Fiodorov I.G. (2015) Adaptatsiya ontologii Bunge-Vanda-Vebera k opisaniyu ispolnyaemykh modeley biznes-protsessov [Adaptation of Bunge-Wand-Weber ontology to description of executable business processes models]. Applied Informatics, no. 4 (58), pp. 82-92 (in Russian).

15. Babkin E.A. (2010) O ponyatii sobytiya v diskretno-sobytiynom modelirovanii [On the concept of event in discrete-event modeling]. Information Systems. Theory and Practice. Kursk: Kursk State University, pp. C. 46-51 (in Russian).

16. Pavlovskiy Yu.N., Belotelov N.V., Brodskiy Yu.I. (2008) Imitatsionnoe modelirovanie [Simulation modeling]. Moscow: Academy (in Russian).

17. Kuznetsov S.D. (2005) Osnovy baz dannykh [Fundamentals of databases]. Moscow: INTUIT (in Russian).

18. Curtis B., Kellner M., Over J. (1992) Process modeling. Communications of the ACM, vol. 35, no. 9, pp. 75-90.

19. Bruza P.D., van der Weide T.P. (1993) The semantics of Data Flow Diagrams. Proceedings of the International Conference on Management of Data, Prentice Hall, pp. 1-13.

20. Schruben L. Simulation modeling with event graphs (1983) Communications of the ACM, vol. 26, no. 11, pp. 957-963.

21. Storrle H. (2000) Models of Software Architecture. Design and analysis with UML and Petri-nets. Munchen: Ludwig-Maximilians-Universitat.

22. Shalyto A.A. (1998) SWITCH-tekhnologiya. Algoritmizatsiya i programmirovanie zadach logicheskogo upravleniya [SWITCH-technology. Algorithmization and programming of logical control tasks]. Saint Petersburg, Nauka (in Russian).

23. Booch G., Maksimchuk R. (2008) Ob”ektno-orientirovannyy analiz i proektirovanie s primerami prilozheniy [Object-oriented analysis and design with applications]. Moscow: Williams (in Russian).

24. Kalashian A.N., Kalianov G.N. (2003) Strukturnye modeli biznesa: DFD-tekhnologii [Structured models of business: DFD technologies]. Moscow: Finance and Statistics (in Russian).

25. Whitten L., Bentley K., Dittman J. (2004) Systems analysis and design methods. McGraw-Hill Companies.

26. Ter Hofstede A., van der Aalst W., Adams M., Russell N. (2010) Modern business process automation. Springer Verlag.

27. Van der Aalst W., van Hee K., ter Hofstede A., Sidorova N., Verbeek H., Voorhoeve M., Wynn M. (2011) Soundness of workflow nets: Classification, decidability, and analysis. Formal Aspects of Computing, vol. 23, no. 3, pp. 333-363.

28. Zachman J.A. (2003) The Zachman Framework: A primer for enterprise engineering and manufacturing. Available at: http://www.zachmaninternational.com (accessed 15 January 2015).

29. Vernadat F. (1996) Enterprise integration: On business process and enterprise activity modeling. Concurrent Engineering: Research and Applications, vol. 4, no. 3, pp. 219-228.

30. Scheer A.W., Nüttgens M. (2002) ARIS Architecture and reference models for business process management. Business Process Management. Springer Lecture Notes in Computer Science, vol. 1806, pp. 376-389.

31. Yourdon E. (1988) Modern structured analysis. Prentice Hall.

32. Mellor S., Balcer M. (2002) Executable UML. A foundation for model-driven architecture. Boston, MA: Addison-Wesley.

33. Wand Y., Weber R. (1999) An ontological model of an information system. IEEE Transactions on Software Engineering, vol. 16, no. 11, pp. 1282-1292. 


\title{
Преодоление дефицита выразительной способности языков моделирования бизнес-процессов ${ }^{1}$
}

\author{
И.Г. Фёдоров \\ кандидат технических наук \\ доцент кафедры прикладных информационных систем и информационной безопасности \\ Российский экономический университет им. Г.В. Плеханова \\ Адрес: 119501, г. Москва, ул. Нежинская, д. 7 \\ E-mail: IFedorov@mesi.ru
}

\begin{abstract}
Аннотация
Я. Ванд и Р. Вебер предположили, что «онтологическое» качество языка моделирования, можно оценить путем сравнения алфавита этого языка с конструкциями предлагаемой ими онтологии верхнего уровня, получившей название Бунге-Ванда-Вебера (BWW). Одним из главных факторов успеха использования языка они называют его способность предоставить пользователям набор знаков (примитивов моделирования), которые могут непосредственно отображать соответствующие концепты (абстракции) онтологии. Однако онтология не сводится к тезаурусу, онатакже включаетспецификациюструктуры соответствующейпроблемной области. Можно предположить, что язык моделирования должен быть способен передать эти связи. Таким образом, подход Я. Ванда и Р. Вебера можно существенно развить, если исследовать структурные связи между концептами онтологии BWW. B работе предпринята попытка расширить онтологию BWW применительно к моделированию бизнес-процессов. Добавлены трансформации, которые изменяют взаимные свойства, им соответствуют логические операторы процесса, изменена трактовка концепта событие, таким образом, что оно фиксирует момент времени, когда происходит изменение состояния внешнего объекта. Показано, что внешние события связаны с каждой операцией процесса. Тем самым добавлены понятия темпоральной логики: момент времени и интервал времени между двумя последовательными событиями. Исследование связей между концептами расширенной онтологии BWW позволило обосновать пять перспектив модели процесса и выделитьформализмы, используемые для ихописания: информационную - диаграмма «сущностьсвязь»; поведенческую - диаграмма состояний; трансформационную - диаграмма потоков данных; темпоральную - граф состояний; логическую - обычные сети Петри. Многочисленные исследования показывают, что языки и нотации моделирования процессов не способны отобразить сразу все концепты онтологической модели BWW, но только их часть. При этом авторы исследований концентрируют внимание на процентном соотношении моделируемых и не моделируемых концептов, подсчитывают относительную степень дефицита, избыточности, неоднозначности и неразличимости. Для преодоления дефицита в данной работе предлагается моделировать бизнес-процесс не в одной нотации, а в нескольких согласованных диаграммах, так, чтобы каждая раскрывала отдельные перспективы модели, а все вместе они образовывали согласованное интегрированные описание.
\end{abstract}

Ключевые слова: моделирование бизнес-процессов, онтологии Бунге-Ванда-Вебера, дефицит выразительной способности, перспективы модели процесса.

Цитирование: Fiodorov I.G. Overcoming expressiveness deficit of business process modeling languages //

Business Informatics. No. 3 (37). P. 62-71. DOI: 10.17323/1998-0663.2016.3.62.71.

\section{Литература}

1. Opdahl A., Henderson-Sellers B. Ontological evaluation of the UML using BWW model // Software and Systems Modeling. 2002. Vol. 1. No. 1. P. 43-67.

2. Recker J., Rosemann M., Krogstie J. Ontology versus pattern-based evaluation of process modeling languages: A comparison // Communications of the Association for Information Systems. 2007. Vol. 48. No. 20. P. 774-799.

3. Green P., Rosemann M. Integrated process modeling. An ontological evaluation // Information Systems. 2000. Vol. 25. No. 2. P. $73-87$.

4. Green P., Rosemann M., Indulska M. Ontological evaluation of enterprise eystems interoperability using ebXML // IEEE Transactions on Knowledge and Data Engineering. 2005. Vol. 17. No. 5. P. 713-725.

${ }^{1}$ Работа выполнена при поддержке Министерства образования и науки России, в рамках базовой части государственного задания № 2014/122 шифр 2966. 
5. Green P., Rosemann M., Indulska M., Manning C. Candidate interoperability standards: An ontological overlap analysis// Data \& Knowledge Engineering. 2007. Vol. 62. No. 2. P. 274-291.

6. Rosemann M., Green P., Indulska M., Recker J. Using ontology for the representational analysis of process modelling techniques // International Journal of Business Process Integration and Management. 2009. Vol. 4. No. 4. 2009. P. 251-265.

7. Фёдоров И.Г. Сравнительный анализ методов моделирования бизнес-процессов // Открытые системы. 2011. № 8. С. $28-30$.

8. Wand Y., Weber R. Research commentary: Information systems and conceptual modeling - A research agenda // Information Systems Research. 2002. Vol. 13. No. 4. P. 363-376.

9. Recker J., Rosemann M., Indulska M., Green P. Business process modeling: A maturing discipline? // BPM Center Report BPM-06-20, 200537 [Электронный pecypc]: http://bpmcenter.org/wp-content/uploads/reports/2006/BPM-06-20.pdf (дата обращения: 15.01.2014).

10. Найханова Л.В. Основные аспекты построения онтологий верхнего уровня и предметной области // В сб.: Интернет-порталы: содержание и технологии. М.: ФГУ ГНИИ ИТТ «Информика». Просвещение, 2005. С. 452-479.

11. Bunge M. Treatise on basic philosophy ontology I: The furniture of the world. Vol 3. Boston, MA: D. Reidel Publishing Company, 1977. $369 \mathrm{p}$.

12. Уемов А.И. Вещи, свойства и отношения. М.: Академия наук СССР, 1963. 184 с.

13. Soffer P., Wand Y. On the notion of soft-goals in business process modeling // Business Process Management Journal. 2005. Vol. 11. No. 6. Р. $663-679$.

14. Фёдоров И.Г. Адаптация онтологии Бунге-Ванда-Вебера к описанию исполняемых моделей бизнес-процессов // Прикладная информатика. 2015. № 4 (58). С. 82-92.

15. Бабкин Е.А. О понятии события в дискретно-событийном моделировании // В сб:: Информационные системы: Теория и практика. Курск: Курский гос. университет, 2010. С. 46-51.

16. Павловский Ю.Н., Белотелов Н.В., Бродский Ю.И. Имитационное моделирование. М.: Академия, 2008. 236 с.

17. Кузнецов С.Д. Основы баз данных. М.: ИНТУИТ, 2005. 488 с.

18. Curtis B., Kellner M., Over J. Process modeling // Communications of the ACM. 1992. Vol. 35. No. 9. P. 75-90.

19. Bruza P.D., van der Weide T.P. The semantics of Data Flow Diagrams // Proceedings of the International Conference on Management of Data. Prentice Hall, 1993. P. 1-13.

20. Schruben L. Simulation modeling with event graphs // Communications of the ACM. 1983. Vol. 26. No. 11. P. 957-963.

21. Storrle H. Models of Software Architecture. Design and analysis with UML and Petri-nets. Munchen: Ludwig-Maximilians-Universitat, 2000. $306 \mathrm{p}$.

22. Шалыто A.A. SWITCH-технология. Алгоритмизация и программирование задач логического управления. СПб: Наука, 1998. $628 \mathrm{c}$.

23. Буч Г., Максимчук Р. Объектно-ориентированный анализ и проектирование с примерами приложений. М.: Вильямс, 2008.720 с.

24. Калашян А.Н., Калянов Г.Н. Структурные модели бизнеса: DFD-технологии. М.: Финансы и статистика, 2003. 234 с.

25. Whitten L., Bentley K., Dittman J. Systems analysis and design methods. McGraw-Hill Companies, 2004. 550 p.

26. Ter Hofstede A., van der Aalst W., Adams M., Russell N. Modern business process automation. Springer Verlag, 2010. 616 p.

27. Soundness of workflow nets: Classification, decidability, and analysis / W. van der Aalst [et al] // Formal Aspects of Computing. 2011. Vol. 23. No. 3. P. $333-363$.

28. Zachman J.A. The Zachman Framework: A primer for enterprise engineering and manufacturing (electronic book). 2003. [Электронный pecypc]: http://www.zachmaninternational.com (дата обращения: 15.01.2015).

29. Vernadat F. Enterprise integration: On business process and enterprise activity modeling // Concurrent Engineering: Research and Applications. 1996. Vol. 4. No. 3. pp. 219-228.

30. Scheer A.W., Nüttgens M. ARIS Architecture and reference models for business process management // Business Process Management. Springer Lecture Notes in Computer Science. 2002. Vol. 1806. P. 376-389.

31. Yourdon E. Modern structured analysis. Prentice Hall, 1988. 688 p.

32. Mellor S., Balcer M. Executable UML. A foundation for model-driven architecture. Boston, MA: Addison-Wesley, 2002. 368 p.

33. Wand Y., Weber R. An Ontological model of an information system // IEEE Transactions on Software Engineering. 1999. Vol. 16. No. 11. P. $1282-1292$. 


\title{
Applying Extended DMAIC methodology to optimize weakly structured business processes ${ }^{1}$
}

\author{
Alexander I. Gromov \\ Professor, Head of Department of Modeling and Optimization of Business Processes \\ National Research University Higher School of Economics \\ Address: 20, Myasnitskaya Street, Moscow, 101000, Russian Federation \\ E-mail:agromov@hse.ru
}

\section{Yulia A. Bilinkis}

Lecturer, Department of Modeling and Optimization of Business Processes National Research University Higher School of Economics Address: 20, Myasnitskaya Street, Moscow, 101000, Russian Federation E-mail:ybilinkis@hse.ru

\section{Nikolay S. Kazantsev}

Lecturer, Department of Modeling and Optimization of Business Processes National Research University Higher School of Economics Address: 20, Myasnitskaya Street, Moscow, 101000, Russian Federation E-mail: nkazantsev@hse.ru

\section{Anastasia G. Zueva}

Lecturer, Department of Modeling and Optimization of Business Processes National Research University Higher School of Economics

Address: 20, Myasnitskaya Street, Moscow, 101000, Russian Federation

E-mail: zueva_ag@mail.ru

\begin{abstract}
The paper is focused on DMAIC methodology, which is currently widely used in projects to optimize routine business processes by implementing 6 Sigma methodologies. The article analyzes the applicability of DMAIC methodology to weakly structured non-linear business processes characterized by uncertainty of the input, output and variability of process instances, primarily dependent on content and user behavior. First, it describes the main steps of the methodology: Define, Measure, Analyze, Improve and Control. These steps are used for a routine documentation approval process. Routine process is regulated and has few exceptions; its instances rarely differ from each other. Standard statistical methods can be used to analyze it, such as control charts. Second, the paper shows approaches to the definition of weakly structured processes with the use of the information field and subject-oriented interaction to achieve the goal. Third, tools and techniques that extend the DMAIC methodology for weakly structured process are proposed using the example of ad-hoc weakly structured operational risk management processes. The main differences were identified in the Define, Measure and Analyze steps. These recommendations can be used in projects to optimize weakly structured processes.
\end{abstract}

Key words: business process, DMAIC, business process optimization, weakly structured business processes.

Citation: Gromov A.I., Bilinkis Yu.A., Kazantsev N.S., Zueva A.G. (2016) Applying Extended DMAIC methodology to optimize weakly structured business processes. Business Informatics, no. 3 (37), pp. 72-79. DOI: $10.17323 / 1998-0663.2016 .3 .72 .79$.

\footnotetext{
${ }^{1}$ The article was prepared within the framework of the Academic Fund Program at the National Research University Higher School of Economics (HSE) in 2016 (grant No. 116-02-0005) and supported within the framework of a subsidy granted to the HSE by the Government of the Russian Federation for the implementation of the Global Competitiveness Program.
} 


\section{Introduction}

$\mathrm{T}$ The methodology of non-linear weakly structured business processes and the principles of their functioning are being developed by scientific and business communities. This is due to the changes in business models of quaternary sector of economy towards an individual approach to the client, intellectualization of the decision-making processes based on the expert assessments and the use of large data, increasing the flexibility and speed of service. A characteristic feature of weakly structured processes is the uncertainty of the input, output and variability of process instances. A high level description of such processes may be stable, but the detailed problems of process instances during their execution are fuzzy and are difficult to replicate, since they are primarily dependent on content and user behavior. Thus, it is almost impossible to create a detailed regulation of the process at the modeling and process automation step and make a decision about all participants in the process and their actions. Typical examples are the processes to produce and provide intellectual services, which are often prevalent in such sectors as the vocational education, science and high technology, information and communication markets, production innovation, intellectual services (consulting, analysis, information brokerage, marketing and banking services, etc.).

This paper proposes an integrated approach to improving management efficiency based on new methods of analysis and monitoring, taking into account the specific characteristics of weakly structured processes which impose restrictions on the use of traditional methods. By effective management we mean reaching the goal for each business process separately while minimizing costs for achievement under the influence of managerial decisions.

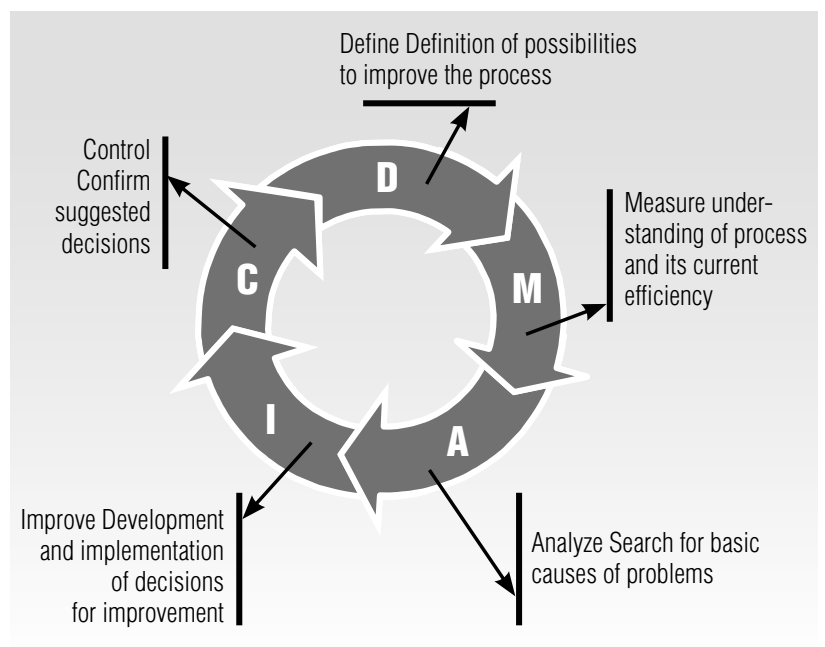

Fig. 1. DMAIC methodology
The objective of this study is to optimize the DMAIC methodology for weakly structured business processes. Consultants often use DMAIC methodology, developed under 6 Sigma concepts as part of a project to improve the operational efficiency of routine business processes (Figure 1).

Traditionally, 6 Sigma is used to set up regular business processes to reduce all types of defects and losses in the production of standardized products and services. As a part of the traditional definition by routine business process we mean a set of interrelated consistent actions having inputs and outputs, covering the different enterprise entities and subordinate to a specific purpose, such as the definition of M. Hammer and T. Davenport. The effectiveness of a structured process is easy to measure taking into account the fact that the set of works is always predetermined and structured. Thus, evaluating the performance of all the components, we can reach a conclusion about the effectiveness of the entire process. As indicators for monitoring, process parameters can be selected which are relevant objectives of each function/sub-process with a certain periodicity of collection; by using them, the organization receives a well-balanced system of indicators of symptoms of problems. DMAIC involves a gradual transition from the general understanding of the most effective solutions to the problems with minimal cost and in the shortest time.

This paper proposes some new tools that can be used at each step of this methodology for weakly structured business processes. Next, we will discuss the application of DMAIC methodology for regulated business process and weakly structured business process.

\section{The first step for routine business processes: Define}

The requirements of customers and business are defined at this step: the Voice of Customers and the Voice of Business, the optimization goal is set, the expert working group is determined, the project charter is defined. This step aims to define clear boundaries of the optimized process and its key participants. It is very important to create a functioning working group at this stage. Such group will include the direct executors of the process. It is necessary to create a detailed process map for uniquely detailed understanding of its functioning.

It is important to identify defects in the process of understanding the consumer ("voice of the customer"). Consumers are not obliged to express their wishes for the process in a clear format; the task of the working group 
is to convert them into quantitative indicators that are crucial for quality and to understand the big picture for the right direction for optimization.

Consider a structured description of the business process in terms of subject-oriented approach on the example of a higher-level process of "Quality Management". For the structured business process "Quality Management," you can highlight the following problem ("voice of the customer"): "the annual program to improve the quality management system (QMS) is developed with delays". "Voice of the customer" can be converted to the "voice of the process" - indicators that correspond to the objectives of each function / sub-process with a certain periodicity of collection by which the organization will receive a well-balanced system of indicators of problems. For the afore-mentioned "voice of the process", the problem can be formulated as follows: "preparation of regulatory documents should not exceed three working days after the request is sent". The question arises: how to achieve the goal of " 3 business days"?

\section{The second step for routine business processes: Measure}

TQM postulates that a product or service of poor quality is the result of unpredictable variability of the process or the input parameter at the beginning of the process, or during the execution of the process. They say that the process is statistically controlled when the only source of variation is a natural cause - variability originating from numerous sources and inherent in the process. Natural changes behave as a system of random factors with constant parameters. While all process instances differ, they form a certain pattern as a group; it can be described as a distribution. The reduction of this variation requires management solutions and investment capital (for example, to purchase new equipment). If this is a normal distribution, it is characterized by two parameters: the mean and standard deviation. It is impossible to measure the mean and standard deviation in practice, since this would require the measurement of all possible instances of the process. Instead they use a number of measurements taken over time by measuring the sample mean and sample variance, respectively. Until the distributions of these parameters are within predetermined limits, the process is statistically controlled and natural variations are allowable. If they come out of the specified parameters, this is due to non-random changes that are not inherited by the process. Reduction of variation requires a special analysis of its causes (Figure 2).

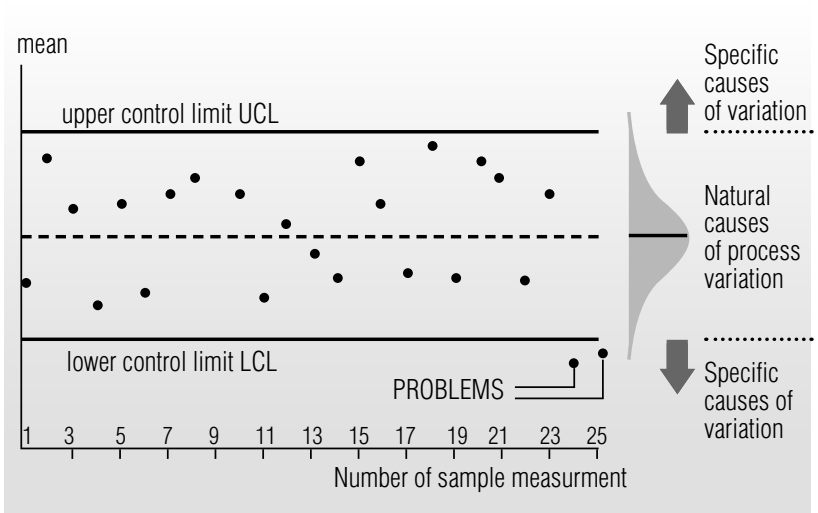

Fig. 2. Natural and special causes of variation

For example, the above process is necessary to consistently measure the time of preparation of regulatory documents for the construction of control charts to obtain information on the number of defects and their dynamics. With the reference sigma level, we conclude the process of statistical control, with levels of specifications a process according to customer requirements.

The measurement system at this point is to collect data for the Analyze step.

\section{The third step for routine business processes: Analyze}

The objective of the quality control system is to supply the statistical signal of the presence of non-random causes. Such a signal can accelerate the adoption of measures aimed at eliminating the causes of non-random. The particular variation can be caused by:

Specific events in the process: the actions of men, change settings, etc.

$\checkmark$ Factors of process groups: in shifts, operators, etc.

$\downarrow$ External factor categories: suppliers, environmental conditions, etc.

For example, in the framework of an expert study for the process we can find that one of the hypotheses about the reason for the delay in submission of documents is the lack of necessary data. After the systematization of the existing information about this issue, it is possible to carry out a production experiment to prove or disprove it.

Relying on all the causes of the problems that can be allocated, it is possible to build a mathematical model of the process $Y=f(x)$. Knowing the model, it is possible to predict the result quite reliably and to adjust the settings according to the factors based on the calculations. Thus, we can move from reactive to proactive process management (Figure 3). 


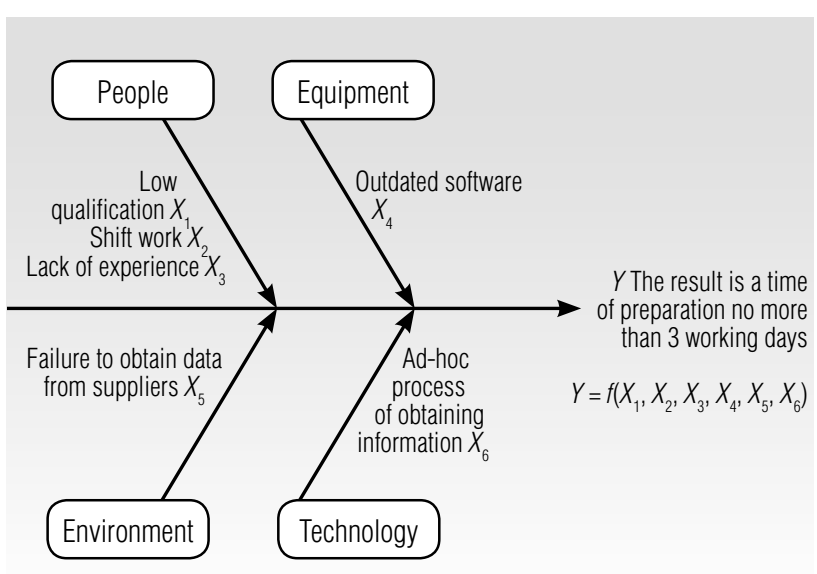

Fig. 3. Process as a transformation function. The result of the process depends on factors (causes)

Thus, the preparation of the documentation depends on the combination of the six main factors and individual measurement systems need to be built for each of them in order to ensure active management of the entire system. To do this, you must determine the exact value of input factors $x_{1}, x_{2}, x_{3}, x_{4}, x_{5}, x_{6}$, providing the desired result value $Y$, as well as the tolerance input parameters $\Delta x_{1}, \Delta x_{2}, \Delta x_{3}, \Delta x_{4}, \Delta x_{5}, \Delta x_{6}$, providing tolerance result $\Delta Y$.

\section{The fourth step for routine business processes: Improve}

At this stage, process optimization solutions are found to meet the performance planned values $x_{1}, x_{2}, x_{3}, x_{4}$, $x_{5}, x_{6}$, and then use any measures to achieve its results. This often entails a change of technological modes, upgrading processes or areas, organizational work with the team.

In this step, solutions for improving the process using the identified factors based on the results of the previous step are developed and implemented. To do this, it is necessary:

$\diamond$ to select the solution by the preliminary expert evaluation of cost and effectiveness;

$\diamond$ to conduct experiments, to evaluate the effectiveness of solutions in the pilot launch (PDCA Cycle) of solutions to remove the problems;

$\diamond$ to evaluate the results of the pilot launch;

$\diamond$ to plan the full deployment of the new process.

For example, for our process it is necessary to create a single distributed data mart with the information about regulatory documents. After this upgrade, it is necessary to stabilize the process parameters on the first pilot solution and then when replicating.

\section{The fifth step for routine business processes: Control}

During this step, the developed solutions are extended and fixed. To do this, it is necessary to design the system for controlling and monitoring the solutions developed, the plan for monitoring the implementation of changes and achieving KPI is to be set, process documentation is updated. The plan for engaging members in the new process is to be set as well, and the final step is to transfer the new process to the Process Owner. All this is necessary for successful replication of the improved process.

\section{Weakly structured processes}

This work is not always being done consistently and with pre-defined structure. According to the modern approach, it becomes clear that the process can contain both structured work and ad-hoc works, often unique challenges. Such processes can be called nonlinear intelligent, dynamic and contextual in nature. The characteristic features of such processes are listed below [1]:

- customization to a specific consumer, i.e. intellectual service cannot be a typical (it is unique): provided to one client, it cannot be intact or provided to another customer, since it requires data recollection, analysis and information presentation;

- association of consumption process with the production process through constant interaction with consumers and fast response to demand;

- a large number of sub-processes and tasks and interdependencies between tasks.

- each process task depends on other tasks, which leads to a large amount of feedback, the availability of information on the previous and subsequent process steps;

- the use of explicit and implicit knowledge of experts. The behavior of process performers depends on their knowledge, which is a constantly changing mix of experience, values and incoming information;

- depending on the context, knowledge of the subject area is used to perform the process, it includes tasks, documents, experts, and other indicators. The performed process is not limited to the orchestration of Web services and the sequence of tasks, but also involves obtaining all relevant information about the process;

- focusing on the executer, collaboration and decisionmaking requires the development and selection of integrated solutions among the fastest possible alternatives 
to achieve some certain goals. Responsibility of employees increases demands on their skills and competence;

- distributed processes. Process participants are not only employees of the company; the successful outcome of the process is highly dependent on corporate communications due to valuable ideas coming from the external environment and outflows of ideas from the company which have no value for it.

For example, in the process of responding to operational risks it can be shown that in the event of an unplanned incident the risk management process will be a search for solutions among community employees, experts in the field. In terms of subject-oriented approach, the subject (member of the process) is the starting point to describe a situation or event. Subjects synchronize their activity through messaging to switch between their functional states. As part of the weakly structured process execution, subjects generate content. With a proper assessment of that content, it is possible to distinguish the purpose of the process and its semantic environment.

The idea of presenting processes with the help of unstructured information has been described by several authors. The formation of an automation system model of an enterprise as a multilayer taxonomy has been made in work [2], where the company is regarded as a "scale significant collection of various information entities", which can be classified by created taxonomy. In work [2], structural units of the enterprise are root taxa, keywords are the end ones and define a business process - operations. Defining ontology and formal models of business processes of a telecommunication enterprise are described in detail in the paper [3], where the taxonomy of business processes was described based on the reference ontology. Then the ontology was created based on real business processes of the organization after their comparison and analysis. Both ontologies have been formed on the basis of a common glossary of terms (Figure 4).

The subject "Initiator" sends a message "The application for the community creation" to subject "Agent" (this is not a human, but an element of an IT system). The "Agent", who has staff profiles, sends two messages with his recommendations on potential participants and their profiles to the "Initiator". Having examined the recommendations and profiles of candidates, the "Initiator" sends an invitation to potential participants and, after receiving consent, creates a new community for problem solving. The formal establishment and registration of the community is operated by the "Agent". A potential investor becomes a participant in the innovation process.

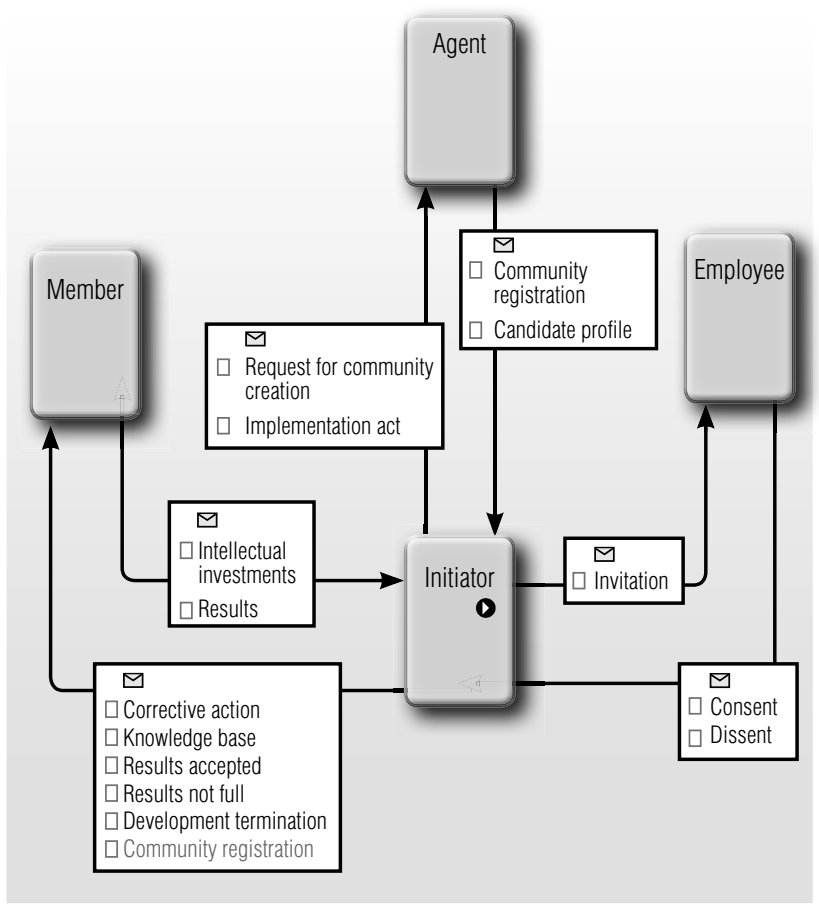

Fig. 4. A weakly structured process

Within the scope of the study, the process is determined as 1) the information field, which is a set of messages which are exchanged between the participants during the process to achieve a certain objective; 2) subjects (participants of the project) - implicit expert knowledge carriers. The information field is given by the characterizing topics of the text information, which in turn are defined by terms. A topic is not just a set of terms (keywords); it is not random, but stable characteristics of a set of semantically related terms characterizing the process. This was confirmed in the works [4-7].

\section{DMAIC for weakly structured business processes}

Here are the distinguishing features of weakly structured processes affecting the instruments of DMAIC methodology.

1. On the Define and Measure steps, it is very difficult to construct a process map. The weakly structured process itself can be defined as a set of concerted efforts of the interacting participants - information and knowledge holders. This is obvious if we consider the activities of the company as a result of the functioning of the socio-techno-economic system. Thus, the activities under process are process-oriented search for the required procedural decisions in the system of distributed information and knowledge. The efficiency of the entire process depends on the efficiency of search management. 
2. The choice of indicators for weakly structured processes on the Measure step is not a trivial task. Very often it's possible to use only delayed parameters of the process result, but in case they are used it is difficult to respond quickly to problems emerging during the process implementation. The advantage of leading indicators is that they have the prognosticating nature and allow the organization to adjust its actions quickly on the basis of comparison of the actual indicators values with planned values. For weakly structured processes, it is recommended to use indicators related with the process information field, as elements of a leading indicators subset.

3. At the Measure step, the measurement is performed; it is gathered data on the problem $(Y)$ and possible root causes $\left(X_{n}\right): Y=f\left(x_{1}, x_{2}, \ldots, x_{k}\right)$, where $Y$ is the result of a process, $X_{n}$ - inputs and internal factors of the process. The purpose for the weakly structured process is clearer than the way of achieving it; therefore, the choice of the way will be determined in the course of achieving the goal based on the information and would not be planned in advance, so it cannot be fixed in a low-level regulations or process model. Defining weakly structured processes can be impractical because of the measurement of the same parameter for different instances of the same business process; different values will be received faster due to the following reasons:

the business process is characterized by complex logical and temporal structure, so a copy of it can be developed in different ways depending on numerous conditions;

objects incoming to the business process for different instances can have different values of the same parameters and that significantly affects the development of the whole business process;

- subject actions of the business process can be changed under the influence of external and internal environments;

४ some activities within the business process related to decision-making can have an informal, unregulated character.
4. The control maps method described above can be used only for structured processes. Control maps cannot be applied if the inputs are not homogeneous, the process is not regular, the output parameters are unique, i.e. for weakly structured processes there must be developed a new approach which enables us:

$\diamond$ to define the nonrandom variation causes of the weakly structured process in order to respond to the situation when process parameters go beyond the scope and thus to identify problems before the client meets them.

$\diamond$ to reduce the variability of the process, to improve the product or process input parameters, thus reducing the likelihood of unpredictable variations impacting the process and leading to problems.

\section{Conclusion}

This paper proposes an integrated approach to improve the efficiency of managing semi-structured processes based on analysis of the applicability of traditional business processes management and the definition of new methods of measurement and analysis allowing for semi-processes. Optimization of DMAIC methodology for weakly structured processes:

- under the Define phase, we provide a method for describing weakly structured process with a data field and a subject-oriented approach;

- under the Measure phase, the identification of nonrandom deviations (bottlenecks, errors) should be done through an analysis of weakly structured information about the process for tracking leading indicators;

- under the Analyze phase, to identify root causes of problems weakly structured process based on an analysis of the information field it is necessary to use the knowledge of experts.

- under Improve and Control phases, to manage semistructured processes for suggested use of standard methodology DMAIC methods proven to be effective.

In general, the results of this work suggest the applicability of DMAIC methodology to weakly structured process management.

\section{References}

1. Dulesov A.S., Khrustalev V.I. (2012) Opredelenie entropii kak mery informatsii pri sopostavlenii prognoznykh i fakticheskikh pokazateley predpriyatiya [Definition of entropy as a measure of information by comparing predicted and actual performance of an enterprise]. Modern Problems of Science and Education, no. 1. Available at: http://www.science-education.ru/ru/article/view?id=5290 (accessed 01 March 2016) (in Russian).

2. Konev K.A. (2013) Kontseptual'naya model' avtomatizatsii predpriyatiya aviatsionnogo priborostroeniya na osnove aktualiziruemoy mnogosloynoy taksonomii [Conceptual model of automation of an aviation instrument making enterprise based on the multi-layer continuously updated taxonomy]. Herald of USATU, vol. 17, no. 5 (58), pp. 70-77 (in Russian).

3. Chistov D.A., Kamaev V.A., Nabokov M.V. (2011) Ontologicheskiy reinzhiniring biznes-protsessov operatora svyazi [Ontological reengineering business processes for a communications operator]. Large-Scale Systems Control, no. 33, pp. 5-20 (in Russian). 
4. Zelenkov Yu.A. (2013) Ob izmerenii effektivnosti biznes-protsessov i podderzhivayushchikh ikh informatsionnykh sistem [On the measurement of the effectiveness of business processes and their supporting information systems]. Large-Scale Systems Control, no. 41, pp. 146-161 (in Russian).

5. Jung J.-Y. (2008) Measuring entropy in business process models. Proceedings of the 3rd International Conference on Innovative Computing Information and Control (ICICIC'08), 18-20 June 2008, Dalian, China. P. 1007-1010.

6. Newman D., Karimi S., Cavedon L. (2009) External evaluation of topic models. Proceedings of the 14th Australasian Document Computing Symposium, 4 December 2009, Sydney, Australia. P. 11-18.

7. Streibel O. Mining trends in texts on the web. Proceedings of the Doctoral Consortium of the 3rd Future Internet Symposium 2010, 23-24 September 2010, Berlin, Germany. P. 80-90.

8. Lopatin V.A. (2008) Sistema upravleniya biznes-protsessami [Control system of business processes]. Management in a Credit Institution, no. 6, pp. 77-99 (in Russian).

9. Keeney R.L., Rife H. (1981) Prinyatie resheniy pri mnogikh kriteriyakh: predpochteniya i zameshcheniya [Decision-making in many criteria: preference and substitution]. Moscow: Radio and Communications (in Russian).

\title{
Применение расширенной методологии DMAIC для оптимизации слабоструктурированных процессов ${ }^{1}$
}

\section{А.И. Громов}

кандидат химических наук, заведующий кафедрой моделирования и оптимизации бизнес-процессов Национальный исследовательский университет «Высшая школа экономики»

Адрес: 101000, г. Москва, ул. Мясницкая, д. 20

E-mail: agromov@hse.ru

\section{Ю.А. Билинкис}

преподаватель кафедры моделирования и оптимизации бизнес-процессов Национальный исследовательский университет «Высшая школа экономики» Адрес: 101000, г. Москва, ул. Мясницкая, д. 20

E-mail:ybilinkis@hse.ru

\section{Н.С. Казанцев}

преподаватель кафедры моделирования и оптимизации бизнес-процессов Национальный исследовательский университет «Высшая школа экономики» Адрес: 101000, г. Москва, ул. Мясницкая, д. 20

E-mail:nkazantsev@hse.ru

\section{А.Г. Зуева}

преподаватель кафедры моделирования и оптимизации бизнес-процессов Национальный исследовательский университет «Высшая школа экономики» Адрес: 101000, г. Москва, ул. Мясницкая, д. 20

E-mail:zueva_ag@mail.ru

\begin{abstract}
Аннотация

\footnotetext{
${ }^{1}$ Статья подготовлена в ходе исследования 116-02-0005 в рамках программы «Научный фонд Национального исследовательского университета «Высшая школа экономики» (НИУ ВШЭ)» в 2016 г., с использованием средств субсидии на государственную поддержку ведущих университетов Российской Федерации в целях повышения их конкурентоспособности среди ведуших мировых научно-образовательных центров, выделенной НИУ ВШЭ.
}

В статье рассмотрена методология DMAIC, которая на данный момент повсеместно используется в проектах оптимизации регламентированных бизнес-процессов, с точки зрения ее применимости к слабоструктурированным нелинейным бизнес-процессам, которые характеризуются неопределенностью входных и выходных данных, а также вариативностью экземпляров процесса, зависимостью от контекста и поведения участников процесса. Во-первых, на примере регламентированного процесса согласования документации описаны основные этапы методологии: Определение (Define), Измерение (Measure), Анализ (Analyze), Улучшение (Improve) и Контроль (Control). Экземпляры регламентированных процессов 
соответствуют предустановленному регламенту и имеют мало исключений. Для их анализа можно использовать стандартные статистические методы, например, контрольные карты. Во-вторых, в статье дается определение слабоструктурированного процесса с помощью понятий информационного поля и субъектно-ориентированного взаимодействия. В-третьих, на примере слабоструктурированного процесса реагирования на операционные риски предложены инструменты и методы, расширяющие методологию DMAIC для оптимизации слабоструктурированного процесса. Основные отличия были обнаружены на этапах Определение (Define), Измерение (Measure) и Анализ (Analyze). Полученные рекомендации могут быть использованы в проектах по оптимизации слабоструктурированных процессов.

Ключевые слова: бизнес-процесс, DMAIC, оптимизация бизнес-процессов, слабоструктурированные бизнеспроцессы.

Цитирование: Gromov A.I., Bilinkis Yu.A., Kazantsev N.S., Zueva A.G. Applying Extended DMAIC methodology to optimize weakly structured business processes // Business Informatics. 2016. No. 3 (37). P. $72-79$.

DOI: $10.17323 / 1998-0663.2016 .3 .72 .79$.

\section{Литература}

1. Дулесов А.С., Хрусталев В.И. Определение энтропии как меры информации при сопоставлении прогнозных и фактических показателей предприятия // Современные проблемы науки и образования. 2012. № 1. [Электронный ресурc]: http://www.scienceeducation.ru/ru/article/view?id=5290 (дата обращения 01.03.2016).

2. Конев К.А. Концептуальная модель автоматизации предприятия авиационного приборостроения на основе актуализируемой многослойной таксономии // Вестник УГАТУ. 2013. Т. 17. № 5 (58). С. 70-77.

3. Чистов Д.А., Камаев В.А., Набока М.В. Онтологический реинжиниринг бизнес-процессов оператора связи // Управление большими системами. 2011. № 33. С. 5-20.

4. Зеленков Ю.А. Об измерении эффективности бизнес-процессов и поддерживающих их информационных систем // Управление большими системами. 2013. № 41. С. 146-161.

5. Jung J.-Y. Measuring entropy in business process models // Proceedings of the 3rd International Conference on Innovative Computing Information and Control (ICICIC' 08), 18-20 June 2008, Dalian, China. P. 1007-1010.

6. Newman D., Karimi S., Cavedon L. External evaluation of topic models // Proceedings of the 14th Australasian Document Computing Symposium, 4 December 2009, Sydney, Australia. P. 11-18.

7. Streibel O. Mining trends in texts on the web // Proceedings of the Doctoral Consortium of the 3rd Future Internet Symposium 2010, 23-24 September 2010, Berlin, Germany. P. 80-90.

8. Лопатин В.А. Система управления бизнес-процессами // Управление в кредитной организации. 2008. № 6. С. 77-99.

9. Кини Р.Л., Райфа Х. Принятие решений при многих критериях: предпочтения и замещения. М: Радио и связь, 1981. 
Articles should be topical and original, should outline tasks (issues), describe key results of the author's research and appropriate conclusions.

Manuscripts are submitted via e-mail: bijournal@hse.ru.

\section{MANUSCRIPT REQUIREMENTS}

TEXT FILES should be submitted in electronic form, as a MS Word document (version 2003 or higher).

LENGTH. Articles should be between 20 and 25 thousand characters (incl. spaces).

FONT, SPACING, MARGINS. The text should be in Times New Roman 12 pt, 1.5 spaced, fit to the width, margins: left - 25 $\mathrm{mm}$, all other $-15 \mathrm{~mm}$.

TITLE of the article should be submitted in native language and English.

AUTHORS' DETAILS are presented in native language and English. The details include:

$\downarrow$ Full name of each author

- Position, rank, academic degree of each author

- Affiliation of each author, at the time the research was completed

$\downarrow$ Full postal address of each affiliation (incl. postcode / ZIP)

$\downarrow$ E-mail address of each author.

\section{ABSTRACT are presented in native language and English.}

$\uparrow$ The abstract should be between 200 and 300 words.

$\downarrow$ The abstract should be informative (no general words), original, relevant (reflects your paper's key content and research findings); structured (follows the logics of results' presentation in the paper)

- The recommended structure: purpose (mandatory), design / methodology / approach (mandatory), findings (mandatory), research limitations / implications (if applicable), practical implications (if applicable), originality / value (mandatory).

$\downarrow$ It is appropriate to describe the research methods/methodology if they are original or of interest for this particular research. For papers concerned with experimental work the data sources and data procession technique should be described.

\ The results should be described as precisely and informatively as possible. Include your key theoretical and experimental results, factual information, revealed interconnections and patterns. Give special priority in the abstract to new results and long-term impact data, important discoveries and verified findings that contradict previous theories as well as data that you think have practical value.

- Conclusions may be associated with recommendations, estimates, suggestions, hypotheses described in the paper.

- Information contained in the title should not be duplicated in the abstract. Authors should try to avoid unnecessary introductory phrases (e.g. «the author of the paper considers...»).

- Authors should use the language typical of research and technical documents to compile your abstract and avoid complex grammatical constructions.

$\downarrow$ The text of the abstract should include key words of the paper.

KEYWORDS are presented in native language and English. The number of key words / words combinations are from 6 to 10 (separated by semicolons).

FORMULAE should be prepared using Math Type or MS Equation tool.

FIGURES should be of high quality, black and white, legible and numbered consecutively with Arabic numerals. All figures (charts, diagrams, etc.) should be submitted in electronic form (photo images - in TIF, PSD or JPEG formats, minimum resolution $300 \mathrm{dpi})$. Appropriate references in the text are required.

REFERENCES should be presented in Harvard style and carefully checked for completeness, accuracy and consistency.

The publication is free of charge. 